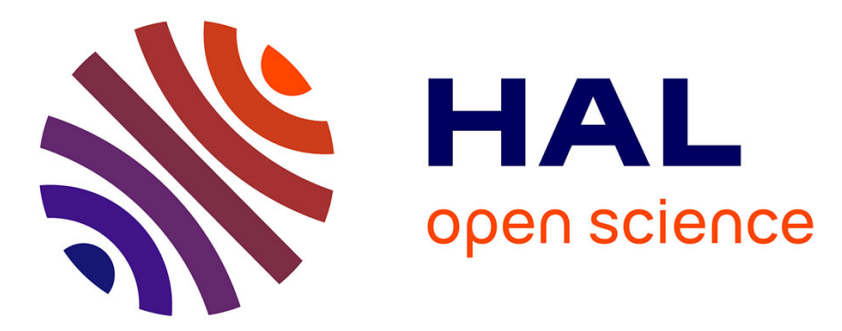

\title{
Investigating the plasma chemistry for the synthesis of carbon nanotubes/nanofibres in an inductively coupled plasma enhanced CVD system: the effect of different gas mixtures
}

M Mao, A Bogaerts

\section{To cite this version:}

M Mao, A Bogaerts. Investigating the plasma chemistry for the synthesis of carbon nanotubes/nanofibres in an inductively coupled plasma enhanced CVD system: the effect of different gas mixtures. Journal of Physics D: Applied Physics, 2010, 43 (20), pp.205201. 10.1088/00223727/43/20/205201. hal-00569604

\section{HAL Id: hal-00569604 \\ https://hal.science/hal-00569604}

Submitted on 25 Feb 2011

HAL is a multi-disciplinary open access archive for the deposit and dissemination of scientific research documents, whether they are published or not. The documents may come from teaching and research institutions in France or abroad, or from public or private research centers.
L'archive ouverte pluridisciplinaire HAL, est destinée au dépôt et à la diffusion de documents scientifiques de niveau recherche, publiés ou non, émanant des établissements d'enseignement et de recherche français ou étrangers, des laboratoires publics ou privés. 


\title{
Investigating the plasma chemistry for the synthesis of carbon nanotubes/nanofibers in an inductively coupled plasma enhanced CVD system: Effect of different gas mixtures
}

\author{
M Mao, A Bogaerts \\ Research Group PLASMANT, Dept. of Chemistry, University of Antwerp, \\ Universiteitsplein 1, B-2610 Antwerp, Belgium \\ Email: ming.mao@ua.ac.be
}

\begin{abstract}
A hybrid model, called the Hybrid Plasma Equipment Model (HPEM) was used to study an inductively coupled plasma in gas mixtures of $\mathrm{H}_{2}$ or $\mathrm{NH}_{3}$ with $\mathrm{CH}_{4}$ or $\mathrm{C}_{2} \mathrm{H}_{2}$ used for the synthesis of carbon nanotubes or carbon nanofibers (CNTs/CNFs). The plasma properties are discussed for the different gas mixture at low and moderate pressure, and the growth precursors for CNTs/CNFs are analyzed. It is found that $\mathrm{C}_{2} \mathrm{H}_{2}, \mathrm{C}_{2} \mathrm{H}_{4}$, and $\mathrm{C}_{2} \mathrm{H}_{6}$ are the predominant molecules in $\mathrm{CH}_{4}$ containing plasmas beside the feedstock gas, and serve as carbon sources for CNT/CNF formation. On the other hand, long chain hydrocarbons are observed in $\mathrm{C}_{2} \mathrm{H}_{2}$ containing plasmas. Furthermore, the background gases $\mathrm{CH}_{4}$ and $\mathrm{C}_{2} \mathrm{H}_{2}$ show a different decomposition rate with $\mathrm{H}_{2}$ or $\mathrm{NH}_{3}$ addition at moderate pressures.
\end{abstract}

\section{Introduction}

Carbon nanotubes (CNTs) were first discovered by Iijima, in 1991 when he synthesized fullerenes $\left(\mathrm{C}_{60}\right)$ in an arc discharge reactor[1]. Since then CNTs gained a lot of attention due to their unique physical, chemical and electronic properties, as well as their wide potential applications including nanoelectronics[2], hydrogen storage[3], and field emission devices[4]. Carbon nanobutes are divided into two categories due to their different structures [5]: singlewalled carbon nanotubes (SWCNTs) and multi-walled carbon nanotubes (MWCNTs). Special structures of MWCNTs are the multi-walled carbon nanofibers (MWCNFs) where the angle between the graphite basal planes and the tube axis is nonzero.

Several methods can be used for the synthesis of CNTs/CNFs, such as arc discharges[6], laser ablation[7], thermal chemical vapour deposition[8], and plasma enhanced chemical vapour deposition (PECVD)[9-31]. Among these growth techniques, PECVD has become a very promising technology for the direct synthesis of vertically aligned CNTs/CNFs used for field emission devices[32-35]. A variety of plasma sources, such as microwave discharges(MW)[9, 10], hot-filament(HF)[11], dc-glow discharges(DC)[12-14, 26, 27], RF capacitively coupled plasmas(CCP)[15, 16] and RF inductively coupled plasmas(ICP)[17-24, 30, 31], have been used to generate a plasma of typical feedstock mixtures such as $\mathrm{CH}_{4}$ or $\mathrm{C}_{2} \mathrm{H}_{2}$ mixed with either $\mathrm{H}_{2}$ or $\mathrm{NH}_{3}$. The recent progress in PECVD for CNT/CNF synthesis has been summarized in table 1 and 2 .

Cui et al.[9] used a microwave $\mathrm{CH}_{4} / \mathrm{NH}_{3}$ plasma and showed that aligned bamboo-like CNTs were deposited under their conditions. The effects of growth temperature and gas phase chemistry variations on the nanotube nucleation and growth structures were investigated. Their results indicated that both substrate temperature and carbon concentration in the gas phase had significant effects on the microstructure of aligned multi-walled tubes. Another demonstration on growing aligned CNTs in microwave $\mathrm{C}_{2} \mathrm{H}_{2} / \mathrm{NH}_{3}$ plasma was reported by Bower et al.[10]. The alignment mechanism was studied in their paper. It was shown that the electrical self-bias 
field imposed on the substrate surface from the plasma environment enabled a vertically oriented growth of MWCNTs.

Optical emission spectroscopy studies were performed by Gulas[11] in a plasma-enhanced hot filament CVD system for CNT growth for comparison with kinetic simulations of the plasma. They found that the formation of $\mathrm{CN}$ and $\mathrm{HCN}$ species significantly changed the density and morphology of the CNTs when $\mathrm{NH}_{3}$ was diluted to the $\mathrm{C}_{2} \mathrm{H}_{2}$ plasma.

Chhowalla et al.[12] explored the growth process conditions for vertically aligned CNTs by dcPECVD. The influence of the Ni catalyst dimensions, bias voltage, deposition temperature, $\mathrm{C}_{2} \mathrm{H}_{2}: \mathrm{NH}_{3}$ ratio and pressure on the formation of the CNTs was studied. They showed that nanotube growth occurred by diffusion of carbon through the Ni catalyst particle, which moved up to the nanotube tip. The plasma composition of a dc $\mathrm{C}_{2} \mathrm{H}_{2} / \mathrm{NH}_{3}$ plasma used for growing vertically aligned CNTs was analyzed by Bell et al.[13] by mass spectrometry. $\mathrm{H}_{2}, \mathrm{~N}_{2}$ and $\mathrm{HCN}$ were found as the major neutral species beside $\mathrm{C}_{2} \mathrm{H}_{2}$ and $\mathrm{NH}_{3}$. The dominant detected ions were $\mathrm{NH}_{3}{ }^{+}$and $\mathrm{C}_{2} \mathrm{H}_{2}{ }^{+}$, besides $\mathrm{NH}_{2}{ }^{+}, \mathrm{NH}_{4}{ }^{+}, \mathrm{HCN}^{+}$and $\mathrm{C}_{2} \mathrm{H}^{+}$. The role of $\mathrm{NH}_{3}$ in CNT growth was investigated in their work. They found that $\mathrm{NH}_{3}$ had two key roles in the CNT formation: generating atomic hydrogen to remove excess carbon and suppressing the decomposition of acetylene. An optimum $\mathrm{C}_{2} \mathrm{H}_{2} / \mathrm{NH}_{3}$ gas ratio of around 20/80 was determined in the experiment giving rise to a minimum in $\mathrm{H}_{2}$ density. Hofmann et al.[14] have successfully grown vertically aligned CNFs at a temperature as low as $120^{\circ} \mathrm{C}$ using a dc-PECVD system. A systematic study of the temperature dependence of the growth rate indicated a lower activation energy of $0.23 \mathrm{eV}$ in the PECVD system than in the thermal CVD system (1.2-1.5eV). They suggested that the diffusion of carbon on the catalyst surface is the rate-determining step at low temperature. Okita et al.[15] investigated the effects of hydrogen on CNT formation in a capacitive $\mathrm{CH}_{4} / \mathrm{H}_{2}$ plasma in the pressure range of 1 10 Torr, a total flow rate of $30 \mathrm{sccm}, 4 \mathrm{~W}$ input power and a growth time of 10 90 minutes. They concluded that the gas ratio of $\mathrm{CH}_{4} / \mathrm{H}_{2}=27 / 3$ at a growth time of 10 minutes was efficient for CNT growth, and the amount of carbon atoms in the CNT agreed well with results from 1D fluid simulations (see below). The hydrogen etching effect on CNTs was also studied by performing $\mathrm{H}_{2}$ plasma treatment on as-grown CNTs. Their results indicated that MWCNTs were not etched by the $\mathrm{H}_{2}$ plasma. Two-dimensional carbon nanowalls were deposited in CCP-PECVD with $\mathrm{C}_{2} \mathrm{~F}_{6}\left(\mathrm{CH}_{4} / \mathrm{CF}_{4}\right) / \mathrm{H}_{2}$ mixtures by Hiramatsu et al.[16]. Indeed, the authors found that the carbon nanowalls grown using $\mathrm{CH}_{4} / \mathrm{H}_{2}$ were waved and thin instead of vertically aligned.

The plasma most often used in the literature for CNT/CNF growth is the ICP. Delzeit and coworkers[17] carried out a study of growing MWCNTs on silicon substrates with multilayered $\mathrm{Al} / \mathrm{Fe}$ catalysts in an inductively coupled $\mathrm{CH}_{4} / \mathrm{H}_{2}$ plasma. A detailed parametric study was undertaken by varying the inductive power, pressure, temperature, gas composition, catalyst thickness, and the bias power on the substrate. The detailed experimental conditions are listed in Table 2. Due to the low inductive power, the system worked in the capacitive mode (the socalled E-mode). A transition from MWCNTs to MWCNFs was observed when increasing the bias power on the lower substrate. Their global simulation showed an electron temperature and electron density of about $1.75 \mathrm{eV}$ and $\sim 10^{11} \mathrm{~cm}^{-3}$ at the conditions under study.

Cruden et al.[18] applied ultraviolet absorption and optical emission spectroscopy under conditions similar to[17] (see Table 2). The density of $\mathrm{CH}_{3}$ detected in the plasma was in the order of $10^{13} \mathrm{~cm}^{-3}$, and increased with pressure and power. The gas temperature was estimated between 700 and $1000 \mathrm{~K}$, i.e. less than the growth temperature of $1273 \mathrm{~K}$ on the substrate. An effective electron temperature of around $2.5-3.3 \mathrm{eV}$ was obtained.

Similar studies were performed by Matthews et al.[19] in the same ICP reactor as Delzeit but with a $\mathrm{C}_{2} \mathrm{H}_{4} / \mathrm{H}_{2}$ mixture. Both MWCNTs and MWCNFs were synthesized. It was concluded that the bias power on the substrate played a key role in the transition from MWCNTs to MWCNFs. At a high substrate power free-standing MWCNFs could be grown. In addition, their results further indicated that the ion bombardment weakened the adhesion of the catalyst particles and lead to the tip growth mode under high substrate power. 
An effort of synthesizing SWCNTs at low temperature in an ICP-PECVD system was reported by Yang and co-workers[20, 21]. The low ICP power was found more efficient for SWCNT growth under their conditions.

Ostrikov et al[22] used a low-frequency $(0.46 \mathrm{MHz})$ ICP-PECVD system to deposit carbon nanostructures with a mixture of $\mathrm{Ar} / \mathrm{H}_{2} / \mathrm{CH}_{4}$. Their results indicated that the aligned carbon nanotip structures were predominantly grown by the molecular and radical units, whereas the plasma-grown nanoparticles were crucial components of polymorphous carbon films.

Vertically aligned carbon nanofibers were synthesized by Caughman et al.[23] using an ICPPECVD system at $50 \mathrm{mTorr}$ in a mixture of $\mathrm{C}_{2} \mathrm{H}_{2} / \mathrm{H}_{2}$. The other conditions are listed in Table 2. They found that nanofibers grown in hydrogen-rich plasma tend to be straight and cylindrical, while those grown in carbon-rich plasma tend to be broad-based and conelike. Their optical emission measurements indicated that surface reactions play a key role in the plasma chemistry and that hydrogen and molecular carbon $\left(\mathrm{C}_{2}\right)$ could be related to the growth results.

Lin and co-workers reported an experimental investigation of an inductive $\mathrm{C}_{2} \mathrm{H}_{2} / \mathrm{H}_{2}$ plasma under a pressure of $20 \mathrm{mTorr}$ and $500{ }^{\circ} \mathrm{C}$ for $\mathrm{CNF}$ growth[24]. They have measured the intensities of $\mathrm{C}_{2}$ species and $\mathrm{H}$ atoms by optical emission spectroscopy, as well as the energy and flux of ions incident on the substrate surface by an impedance meter. The line intensity of $\mathrm{C}_{2}$ was found to increase with $\mathrm{C}_{2} \mathrm{H}_{2} / \mathrm{H}_{2}$ ratio while the hydrogen atom density decreased accordingly. The relative density of $\mathrm{C}_{2}$ and $\mathrm{H}$ atoms, as well as the ion current collected by the substrate electrode, increased with ICP power, which led to the increase of the growth rate of the CNFs. Moreover the etch effect upon the effective removing of the $\alpha-\mathrm{C}$ on the catalyst surface is further enhanced by ion bombardment.

Wei[25] carried out a comprehensive study of the growth of vertically-aligned CNFs in an ICPPECVD system under the conditions mentioned in Table 2. Mass spectroscopy was used to determine the plasma composition in the experiments. Long chain hydrocarbons were detected in their experiments, which poisoned the catalyst and prevented the growth of CNFs. The $\alpha-C$ on the catalyst surface could be efficiently removed by decreasing the gas pressure. The influence of dilution of $\mathrm{NH}_{3}$ was also investigated.

To control CNT/CNF growth, it is necessary to have a good insight in the plasma behaviour. This can be obtained by computer simulations. Several efforts have been attempted in the past decades. A one-dimensional simulation was carried out by Hash et al.[26, 27] for a de plasma used for CNT growth with a gas mixture of $\mathrm{Ar} / \mathrm{C}_{2} \mathrm{H}_{2} / \mathrm{NH}_{3}$. 24 species and 140 reactions were taken into account in their model. The simulation conditions were a pressure of 8 Torr, a flow rate of $100 \mathrm{sccm}$ of argon, $50 \mathrm{sccm}$ of $\mathrm{NH}_{3}$ and $25 \mathrm{sccm}$ of $\mathrm{C}_{2} \mathrm{H}_{2}, \mathrm{~T}_{\text {substrate }}$ of $700{ }^{\circ} \mathrm{C}, \mathrm{T}_{\text {wall }}$ of $450{ }^{\circ} \mathrm{C}$. A complete dissociation of $\mathrm{NH}_{3}$ was observed in the simulations at relatively low bias of $-325 \mathrm{~V}$. The $\mathrm{Ar}^{+}$ions were found the dominate ions followed by $\mathrm{C}_{2} \mathrm{H}_{2}{ }^{+}$and $\mathrm{NH}_{4}{ }^{+}$. The effect of bias on gas temperature was also discussed in the paper.

The amount of carbon in CNTs grown by a capacitvely coupled (CC) $\mathrm{CH}_{4}$ plasma was predicted by Okita et al.[28] using one-dimensional fluid simulations combined with experimental measurements. The simulation results were consistent with experiment. The effects of hydrogen and pressure on the CNT formation in a $\mathrm{CC} \mathrm{CH}_{4} / \mathrm{H}_{2}$ plasma was further investigated in [29]. $\mathrm{H}$, $\mathrm{CH}_{3}, \mathrm{CH}_{5}{ }^{+}$and $\mathrm{C}_{2} \mathrm{H}_{5}{ }^{+}$were found to be the major radicals and ions, respectively. By analyzing the pressure dependence, the results suggested that both radical and non-radical neutrals played an important role as CNT growth precursors.

Denysenko et al.[30] performed detailed numerical simulations with a global model for depositing vertically aligned carbon nanostructures in an ICP-PECVD system. A gas mixture of $\mathrm{Ar} / \mathrm{CH}_{4} / \mathrm{H}_{2}$ was used in their study. The densities and fluxes of radicals and charged species as well as the effective electron temperature, and methane conversion factor were calculated under various conditions. Their results showed that the deposited cation fluxes generally exceed those of the radical neutrals. The conversion rates of methane and hydrogen was found very high $(\sim 99 \%)$ in their study. Furthermore, Ostrikov et al.[31] reported a two-dimensional simulation of nanoassembly precursor species in an inductive $\mathrm{Ar} / \mathrm{H}_{2} / \mathrm{C}_{2} \mathrm{H}_{2}$ plasma. The number density and fluxes of the main building blocks and surface preparation species involved in the nanoassembly 
of carbon-based nanopatterns were calculated in their study. They showed that the nanopattern quality might be affected by the process parameters and the non-uniformity of the surface fluxes of each particular species.

The current status of the technology of depositing CNTs by PECVD, including equipment, plasma chemistry, diagnostics and modelling, as well as mechanisms, was recently reviewed by Meyyappan[36]. It is stated that significant progress was achieved in the use of plasma-grown structures for various applications, but modelling efforts were very minimal[36].

From the literature review above, we can see that CNTs/CNFs could be synthesized under either moderate pressure (1 10 Torr) or low pressure (10s of mTorr) in a PECVD system (see Table 1 and 2). During the synthesis process, methane $\left(\mathrm{CH}_{4}\right)$ and acetylene $\left(\mathrm{C}_{2} \mathrm{H}_{2}\right)$ are popular feedstock gases for the carbon source. A dilution by $\mathrm{H}_{2}$ and $\mathrm{NH}_{3}$ is often used to obtain hydrogen-rich plasmas, in order to produce 'clean' CNTs/CNFs. However, most of the above works focus on how to grow CNTs/CNFs in low-temperature PECVD, whereas the role of the plasma during the process of synthesizing CNTs/CNFs, as well as the key precursors for CNT growth, still remain more or less unclear.

To investigate the plasma chemistry for a CNT-PECVD system, a systematic study with the 2D Hybrid Plasma Equipment Model (HPEM)[37-42] is carried out in our group. An ICP reactor, more specifically, a transformer coupled plasma (TCP) reactor is used in the simulations for two reasons: first, the TCP system is widely used in the semiconductor industry, because it is simple to construct and offers high ionization efficiency compared to dc or RF capacitive discharges. In addition, the TCP reactor has an independent RF power supply to the substrate which can be useful in the growth of nanotubes in vertical alignment. Second, some experimental effort has been explored on synthesizing nanotubes in such system in the past decades[17-19]. These experimental data can be used to validate our simulation results.

Four kinds of feedstock gas mixtures (i. e., $\mathrm{CH}_{4} / \mathrm{H}_{2}, \mathrm{CH}_{4} / \mathrm{NH}_{3}, \mathrm{C}_{2} \mathrm{H}_{2} / \mathrm{H}_{2}$, and $\mathrm{C}_{2} \mathrm{H}_{2} / \mathrm{NH}_{3}$ ) are studied in this work for two different pressures: 50 mTorr and 1 Torr, corresponding to the low and moderate pressure range investigated in the experiments (see above and Table 2). The paper is organized as follows: a short description of the model is given in section 2, followed by the plasma chemistry of $\mathrm{CH}_{4} / \mathrm{H}_{2}\left(\mathrm{NH}_{3}\right)$ and $\mathrm{C}_{2} \mathrm{H}_{2} / \mathrm{H}_{2}\left(\mathrm{NH}_{3}\right)$. In section 3, the numerical results are discussed. The conclusion and outlook will be summarized in section 4 .

\section{Description of the model}

\subsection{The Hybrid Plasma Equipment Model}

The Hybrid Plasma Equipment Model (HPEM) has been developed at the University of Illinois by Kushner and coworkers[37-42] and addresses the plasma physics and chemistry in a modular fashion. The HPEM has been applied to a variety of reactor types in low temperature plasmas[43]. The main modules of HPEM are the Electromagnetic Module (EMM), Electron Energy Transport Module (EETM), and Fluid Kinetics Module (FKM). The plasma quantities are generated by iterating between these different coupled modules. A short review of these three modules is given in the following, more details can be found in the publications of Kushner et al., the developers of the HPEM[37-42].

After defining the reactor geometry and initial operating conditions, the first module EMM calculates the electromagnetic fields within the reactor volume by solving Maxwell equations. These fields are used as inputs in the EETM, where the electron density, electron temperature, electron energy distribution function and electron impact reaction rates are computed with a Monte Carlo procedure or the Boltzmann equation. Subsequently, the FKM calculates densities and fluxes of the various plasma species (i.e. heavy particles and electrons) with continuity equations, and the electrostatic field with Poisson's equation. This electrostatic field is used as input again in the EMM. This cycle is iterated until convergence. The schematic of the modular HPEM is given in Fig. 1.

\subsection{The plasma chemistry for CNT/CNF growth}


As mentioned above, the plasma species densities are calculated with continuity equations, i.e., balance equation with different production and loss terms, determined by chemical reactions. The latter are specific for each gas mixture under study.

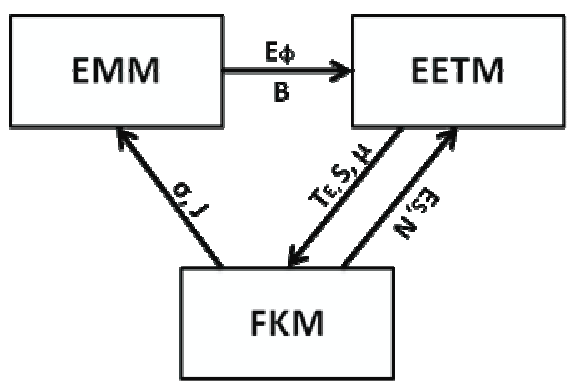

Figure 1. Schematic of the modular HPEM

a. Methane-hydrogen plasma chemistry $\left(\mathrm{CH}_{4} / \mathrm{H}_{2}\right)$

$\mathrm{CH}_{4}$ and $\mathrm{CH}_{4} / \mathrm{H}_{2}$ plasmas have been used very frequently in ICP reactors for CNT formation in the past decades[15, 17, 18, 20, 21, 28-30].

After a sensitivity analysis, 33 species (electrons, ions, radicals and background neutrals) along with 58 electron impact reactions, 115 ion-neutral reactions, and 45 neutral-neutral reactions are taken into account in our model. The details are listed in Tables 3-6. Besides the inlet gas $\left(\mathrm{CH}_{4} / \mathrm{H}_{2}\right)$, some higher order neutral molecules $\left(\mathrm{C}_{3} \mathrm{H}_{8}, \mathrm{C}_{2} \mathrm{H}_{6}, \mathrm{C}_{2} \mathrm{H}_{4}, \mathrm{C}_{2} \mathrm{H}_{2}\right)$ are also included in our model, because they were found to be formed in the plasma at high densities[44]. Some radical and ionic species (e.g. $\mathrm{C}_{3} \mathrm{H}_{\mathrm{x}}, \mathrm{C}_{3} \mathrm{H}_{\mathrm{y}}{ }^{+}, \ldots$ ) as well as the negative ions are not incorporated in the model, although they might be present in a $\mathrm{CH}_{4}$ plasma, but they have much lower densities. Note that the electron impact reactions are treated with energy dependent cross sections, whereas the ion and neutral reactions are described by rate coefficients.

\section{b. Acetylene-hydrogen plasma chemistry $\left(\mathrm{C}_{2} \mathrm{H}_{2} / \mathrm{H}_{2}\right)$}

$\mathrm{C}_{2} \mathrm{H}_{2}$ is another popular gas used for the synthesis of carbon nano-films and carbon nanotubes [10-14, 23-27, 31]. Compared to methane, it can yield more highly polymerized ions and has a much stronger and faster tendency to form dust. The measurement of Deschenaux et al.[45] showed the formation of higher mass hydrocarbon cations and anions up to nearly 200 amu. The dominance of the species with an even carbon atom number is a distinct feature of $\mathrm{C}_{2} \mathrm{H}_{2}$ discharges.

One-dimensional fluid simulations of capacitive $\mathrm{C}_{2} \mathrm{H}_{2}$ plasmas have been performed for nanoparticle formation by De Bleecker et al.[46] and Mao et al.[47] in our group. The results showed that negative ions played a key role during the nanoparticle formation. However, the negative ions are not included in the current study because our preliminary simulations based on the mechanism proposed in [47] show that the magnitude of negative ions is at least one order smaller than that of electrons in an inductive acetylene discharge. Therefore the negative ions will not be considered in the current study to save computational effort.

Table 7 gives an overview of the 47 different species besides electrons considered in the model. The type of species included in the model is based on experimental observations of Deschenaux. et al.[45]. There are indeed more highly polymerized ions and neutrals included than in the $\mathrm{CH}_{4} / \mathrm{H}_{2}$ model (c.f. Table 3). 105 reactions involving 31 electron-impact reactions, 29 neutralneutral reactions and 45 ion-neutral reactions are taken into account (see tables 8 -10).

\section{c. Addition of ammonia $\left(\mathrm{NH}_{3}\right)$}

When $\mathrm{NH}_{3}$ is used as dilution gas instead of $\mathrm{H}_{2}$, an extra number of 22 species, 43 electronimpact reactions, 48 ion-neutral reactions and 67 neutral-neutral reactions were added to the model. All the details are given in tables 11-14.

\subsection{Diffusion and wall deposition losses}


Besides chemical reactions in the discharge, species can also be lost by diffusion to the reactor walls followed by deposition. The overall diffusion coefficient $D_{j}$ of neutral species $j$ in the gas mixture can be calculated by Blanc's law[48],

$$
\frac{p_{t o t}}{D_{j}}=\sum_{i} \frac{p_{i}}{D_{i j}}
$$

where $D_{i j}$ is the binary diffusion coefficient of species $j$ in every background gas $i$ [49],

$$
D_{i j}=\frac{3}{16} \frac{k_{B} T_{g a s}}{p_{t o t}} \frac{4 \pi k_{B} T_{g a s} / m_{i j}^{1 / 2}}{\pi \sigma_{i j}^{2} \Omega_{D}(\Psi)}
$$

$k_{B}$ is the Boltzmann constant, $T_{\text {gas }}$ is the gas temperature in Kelvin, $p_{t o t}$ is the total gas pressure in Pascal, $m_{i j}$ is the reduced molecular mass in amu, $\sigma_{i j}$ is the binary collision diameter in $\AA$.

$$
\sigma_{i j}=\frac{\sigma_{i}+\sigma_{j}}{2}
$$

and $\Omega_{D}(\Psi)$ is the diffusion collision integral given by[49]

$$
\Omega_{D}=\frac{A}{\Psi^{B}}+\frac{C}{e^{D \Psi}}+\frac{E}{e^{F \Psi}}+\frac{G}{e^{H \Psi}}
$$

with $\Psi=T_{g a s} / \varepsilon_{i j}, \varepsilon_{i j}=\left(\varepsilon_{i}+\varepsilon_{j}\right)^{1 / 2}$ and constants $A=1.06036, B=0.15610, C=0.19300, D=$ $0.47635, E=1.03587, F=1.52996, G=1.76464$ and $H=3.89411$. All data needed to calculate the diffusion coefficients of all the plasma species included in the models were adopted from [44] and [47].

For ions both motilities and diffusion coefficients are considered. The ion mobility of an ionic species $j$ in the background gas $i$ can be calculated from the low-electric-field Langevin mobility expression[48]

$$
\mu_{i j}=0.514 m_{i j}^{-0.5} \frac{T_{g a s}}{P_{t o t}} \alpha_{i}^{-0.5}
$$

where $\alpha_{i}$ in $\AA^{3}$ is the polarizability of the background gas and is taken from [44] and [47] for all ions. The overall ion mobility $\mu_{j}$ of ion $j$ in the gas mixture can again be obtained by Blanc's law; see above. Finally, the ion diffusion coefficient can be derived from Einstein's relation

$$
D_{j}^{ \pm}=\frac{k_{B} T_{i o n}}{e} \mu_{j}
$$

where $T_{i o n}$ represents the ion temperature which is assumed to be equal to the gas temperature.

Finally, a sticking model, where the deposition of species at the wall is described, is applied to treat the plasma-wall interactions. The sticking coefficients assumed for the different radicals can be found in Table 15. For the ions a sticking coefficient of 1 is assumed, because they will be neutralized. For the molecules, a sticking coefficient of 0 is used, as they are considered to be reflected at the walls.

It should be noted that the same sticking model is also applied on the substrate. Indeed, due to the lack of reliable data, the same sticking coefficients are assumed on the substrate as on the other walls. This is of course an approximation, because the substrate for CNT growth is typically covered by metal catalyst nanoparticles (e.g., Ni, Fe, Al, Co; see Table 1 above), and it is generally assumed[50] that the hydrocarbon growth species will decompose at the surface of these nanoparticles. This represents a sink for the hydrocarbon species, which is included in the model by the sticking coefficients, but as the latter are taken as constant values, irrespective of the kind of wall material, it is an approximation.

The present work focuses mainly on the bulk plasma chemistry reactions. However, the model could be further improved by calculating detailed decomposition probabilities of the various hydrocarbon species at the nanoparticle surface, for instance by molecular dynamics simulations, and using these data as boundary conditions for the plasma chemistry model, in order to describe the process of CNT/CNF growth in more detail. 
Alternatively, a separate model for the catalytic growth of CNTs, as was recently developed by Naha and Puri[51], could be combined to our plasma chemistry model. Such a model takes into account several mechanisms including adsorption and desorption of hydrocarbon species at the catalyst-gaseous hydrocarbon interface, surface and bulk diffusion, nucleation, and separation of solid undissolved carbon in nanostructured form. This model needs the predominant carboncontaining species density near the substrate as an input parameter, which is an output of our model. Vice versa, the surface processes provide the boundary conditions for the plasma chemistry model. In the near future, we would like to extend our plasma chemistry model, to take into account the decomposition of the hydrocarbon species at the catalyst nanoparticles in more detail.

\section{Results and discussion}

\subsection{Operating conditions}

The calculations were performed for eight cases, namely for four different gas mixtures: i.e., $\mathrm{CH}_{4} / \mathrm{H}_{2}, \mathrm{CH}_{4} / \mathrm{NH}_{3}, \mathrm{C}_{2} \mathrm{H}_{2} / \mathrm{H}_{2}$, and $\mathrm{C}_{2} \mathrm{H}_{2} / \mathrm{NH}_{3}$, and in each case for two different gas pressures: 50 mTorr representing the low-pressure range and 1 Torr for the moderate-pressure range. The gas ratio is always $20 \%$ for $\mathrm{CH}_{4} / \mathrm{C}_{2} \mathrm{H}_{2}$ vs $80 \% \mathrm{H}_{2} / \mathrm{NH}_{3}$. Other operating conditions are: $100 \mathrm{sccm}$ total gas flow rate, $300 \mathrm{~W}$ source power, $30 \mathrm{~W}$ bias power at the substrate electrode and an operating frequency of $13.56 \mathrm{MHz}$ applied to the coil and to the substrate electrode. The substrate is heated to $550{ }^{\circ} \mathrm{C}$. These are typical operating conditions for CNT growth, as was illustrated in Tables 1-2.

The reactor geometry under study is a TCP reactor, which is often used for CNT growth[17-19]. It is schematically illustrated in Figure 2.

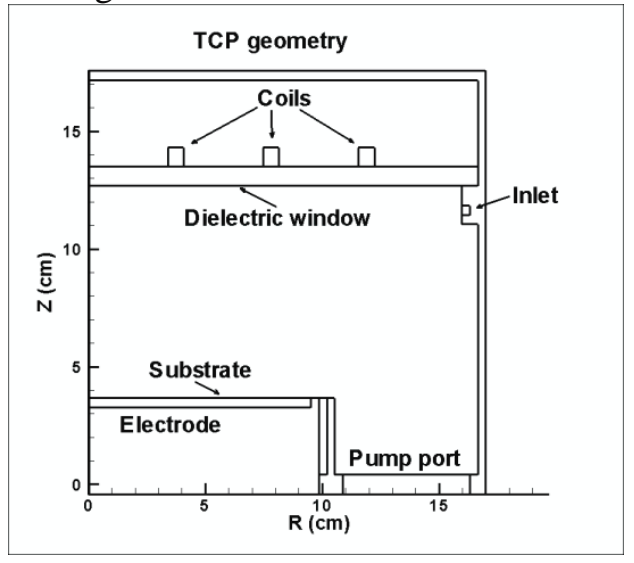

Figure 2: Two-dimensional TCP reactor geometry used in the model. The reactor is cylindrically symmetric, so only one half plane of the reactor is shown.

\subsection{General calculation results}

First we show some general calculated results, for the $\mathrm{CH}_{4} / \mathrm{H}_{2}$ gas mixture, at low pressure (50 mTorr) and moderate pressure (1 Torr). These results are representative for the other gas mixtures as well, unless mentioned otherwise.

The calculated 2D power density profiles at a pressure of 50 mTorr and 1 Torr are shown in figure 3 (a) and (b), respectively. The input power from the RF coil (i.e. 300W) is mainly deposited near the quartz windows below the coil. An off-axial peak is observed at both pressures. When the pressure is increased to 1 Torr, the region of power deposition becomes smaller compared to that at 50 mTorr. This reduction leads to higher peak values of power density at pressures of 1 Torr, because the total input power for both pressures is same (i.e. $300 \mathrm{~W}$ ). The peak values of power density are 0.36 and $0.55 \mathrm{~W} / \mathrm{cm}^{3}$ at $50 \mathrm{mTorr}$ and 1 Torr, respectively. In this region, the plasma electrons absorb the energy from the inductive electric field, which is called the "inductive region". 


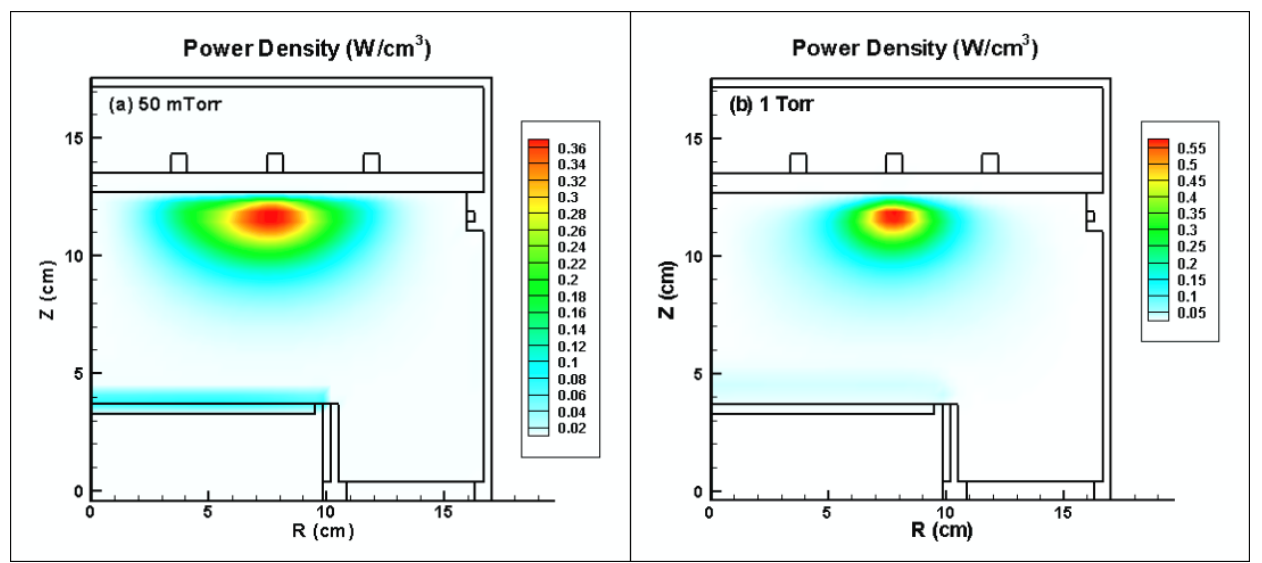

Figure 3 Calculated 2D power density profiles for a $\mathrm{CH}_{4} / \mathrm{H}_{2}$ gas mixture at a pressure of (a) 50 mTorr and (b) 1 Torr with gas ratio of 20:80. The operation conditions are: $100 \mathrm{sccm}$ gas flow rate, $300 \mathrm{~W}$ source power, $30 \mathrm{~W}$ bias power at the substrate and $13.56 \mathrm{MHz}$ operating frequency at the coil and at the substrate electrode. The substrate is heated to $550{ }^{\circ} \mathrm{C}$.

A second region of power deposition can be found above the substrate where the RF bias power of $30 \mathrm{~W}$ is applied. It is clear from Fig. 3(a) and (b) that the power density in this region is fairly uniform. We call this region the "capacitive region" because the electrons absorb the energy mainly from the electrostatic field. The peak values of power density in this region are around 0.07 and $0.02 \mathrm{~W} / \mathrm{cm}^{3}$ at $50 \mathrm{mTorr}$ and 1 Torr, respectively. Indeed at the moderate pressure of 1 Torr, the capacitive region is expanded, which results in a decrease of the maximum power density because the total power applied on the substrate is fixed as $30 \mathrm{~W}$ for both pressures. Similar trends were also observed for the other three gas mixtures.

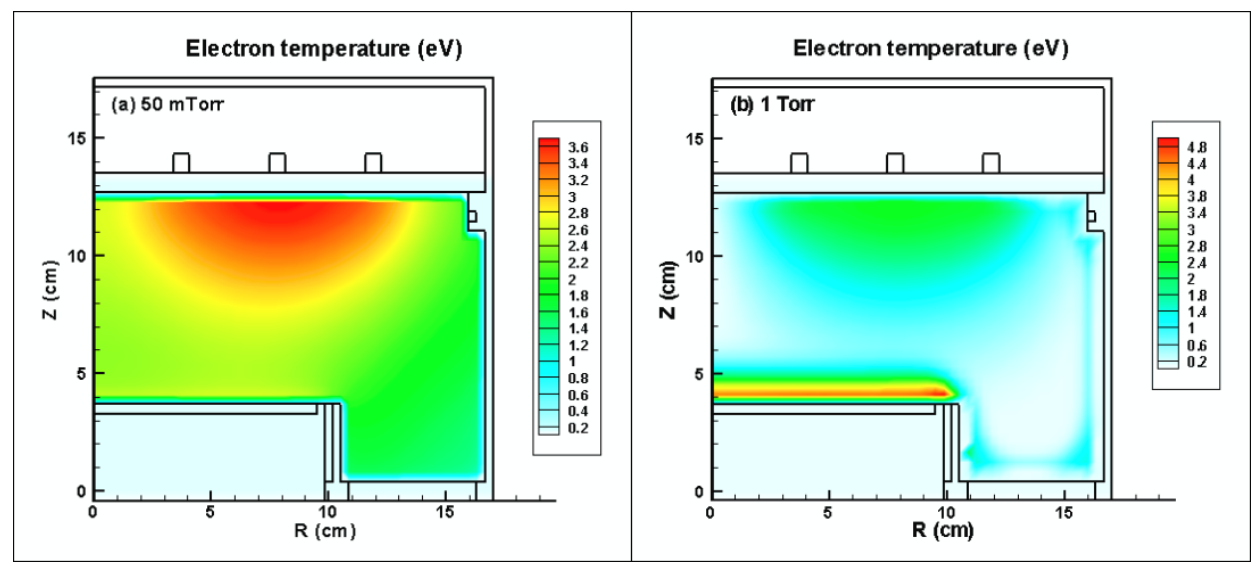

Figure 4 Calculated 2D electron temperature profiles at the same conditions as in figure 3

Figure 4 (a)-(b) displays the calculated 2D distributions of the electron temperature at the two different pressures. Similar to the power deposition, the electron temperature exhibits two peaks, i.e., in the inductive region and capacitive region, where the electrons gain energy from the electric field. At low pressure of $50 \mathrm{mTorr}$, the electron temperature shows values around $2.4 \sim 3.5 \mathrm{eV}$ in the inductive region, which is comparable to the result measured by Cruden et al. in [18]. At the moderate pressure of 1 Torr, the values of electron temperature are reduced to $1 \sim 2.5 \mathrm{eV}$ in the inductive region. These results are consistent with Delzeit et al.[17] and Ostrikov et al.[31]. In addition, the electron temperature remains as high as $4 \sim 6 \mathrm{eV}$ in the capacitive region at 1 Torr. This can be explained because at higher pressure a lower electron density is found in the capacitive region (i.e., around 10 times lower than the density at 50 mTorr; see below). Hence, for a given applied bias power (30W), the electrons will be able to gain more energy. 


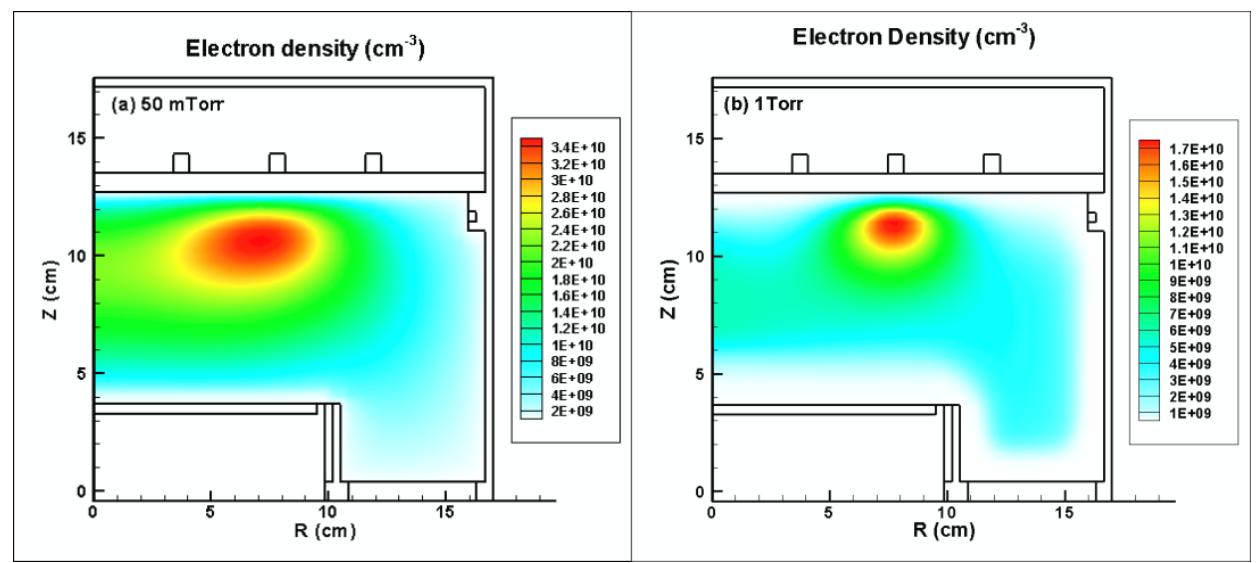

Figure 5 Calculated 2D electron density profiles at the same conditions as in figure 3

Figure 5 illustrates the calculated 2D profiles of the electron densities at the same conditions as in figure 3. Off-axial maxima are also observed for the electron density distribution. This is because in this region the electrons are created by the deposited power. When the pressure is increased to 1 Torr, the distribution of electrons becomes more localized. Indeed at high pressure, there are more collisions between electrons and the other species, so that the mean free path for electrons becomes smaller, and the electrons lose their energy much faster. At 50 mTorr, the electron density shows a peak value of $3.4 \times 10^{10} \mathrm{~cm}^{-3}$ below the coil, and it decreases to $1 \times 10^{9} \mathrm{~cm}^{-3}$ near the walls. Slightly higher values (i.e., $8.5 \times 10^{10} \mathrm{~cm}^{-3}$ in a pure $\mathrm{CH}_{4}$ ICP discharge at a pressure of $50 \mathrm{mTorr}$ and a power of $500 \mathrm{~W}$ ) were reported by Bera et al.[52]. At the moderate pressure of 1 Torr, the peak value of electron density becomes $1.7 \times 10^{10} \mathrm{~cm}^{-3}$. This is because the large number of collisions between electrons and neutrals at the moderate pressure make electrons lose their energy much faster, leading to the reduction of high-energy electrons, which results in a decrease of the electron density.

The calculated 2D profiles of the gas temperature are plotted in figures 6(a)-(b). The substrate is heated to $823 \mathrm{~K}$ (i.e. $550{ }^{\circ} \mathrm{C}$ ). At the low pressure of $50 \mathrm{mTorr}$, the heat transfer towards the plasma is clearly displayed. The gas temperature gradually changes from $823 \mathrm{~K}$ at the substrate to about $600 \mathrm{~K}$ in the bulk plasma, and reaches $324 \mathrm{~K}$ at the wall. On the other hand, at the moderate pressure of 1Torr, the gas temperature sharply decreases near the substrate. Indeed, at higher pressure more "cooling" species are injected into the reactor (400K in our simulation), which leads to more species sharing the heat transferred from the substrate. Second, the collisions between the species become more frequent at higher pressure, so that the species lose their energy more quickly.

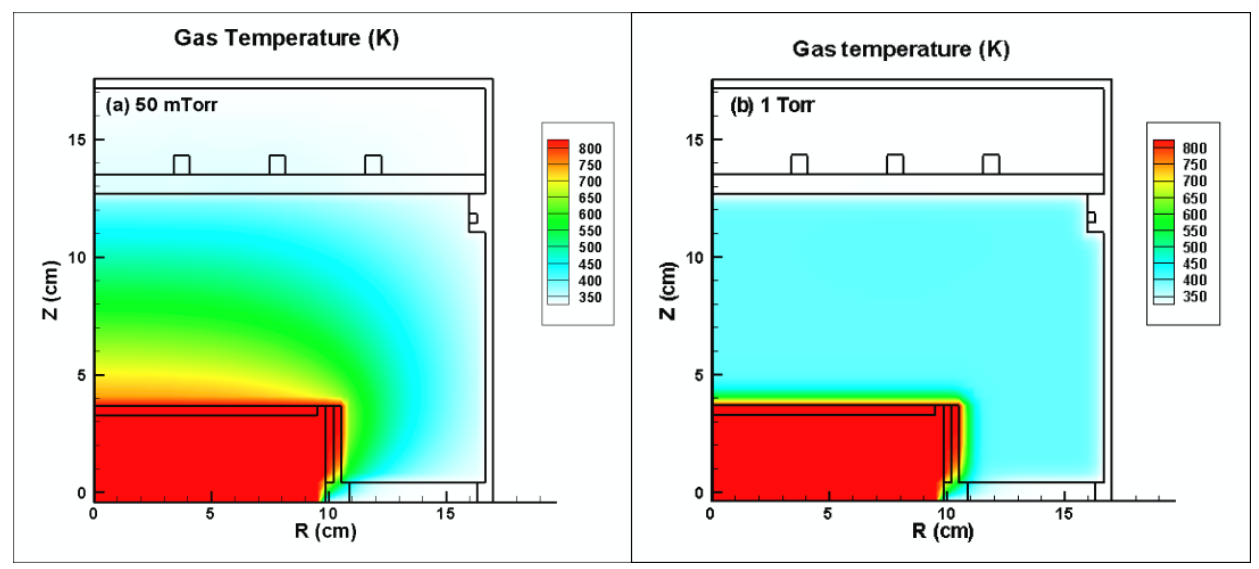

Figure 6 Calculated 2D gas temperature profiles at the same conditions as in figure 3. 
The 2D number density distribution of the background gas $\mathrm{CH}_{4}$ is displayed in figures 7 (a) and (b) at low and moderate pressure, respectively. The density reaches a maximum near the gas inlet and drops in the plasma due to ionization and dissociation reactions as shown in Table 4-6. The $\mathrm{H}$-abstraction reaction $\mathrm{H}+\mathrm{CH}_{4} \rightarrow \mathrm{H}_{2}+\mathrm{CH}_{3}$ is found to be the predominant loss process.

The rate constant for this reaction is very sensitive to the gas temperature (see Table 6) and its magnitude increases two orders when the gas temperature changes from $400 \mathrm{~K}$ to $900 \mathrm{~K}$. Hence, this reaction is much faster at $50 \mathrm{mTorr}$ where a higher gas temperature is reached (cf. figure 6 a and b). This explains why the $\mathrm{CH}_{4}$ density does not drop so rapidly at 1 Torr, as is clear from fig. $7 \mathrm{~b}$.

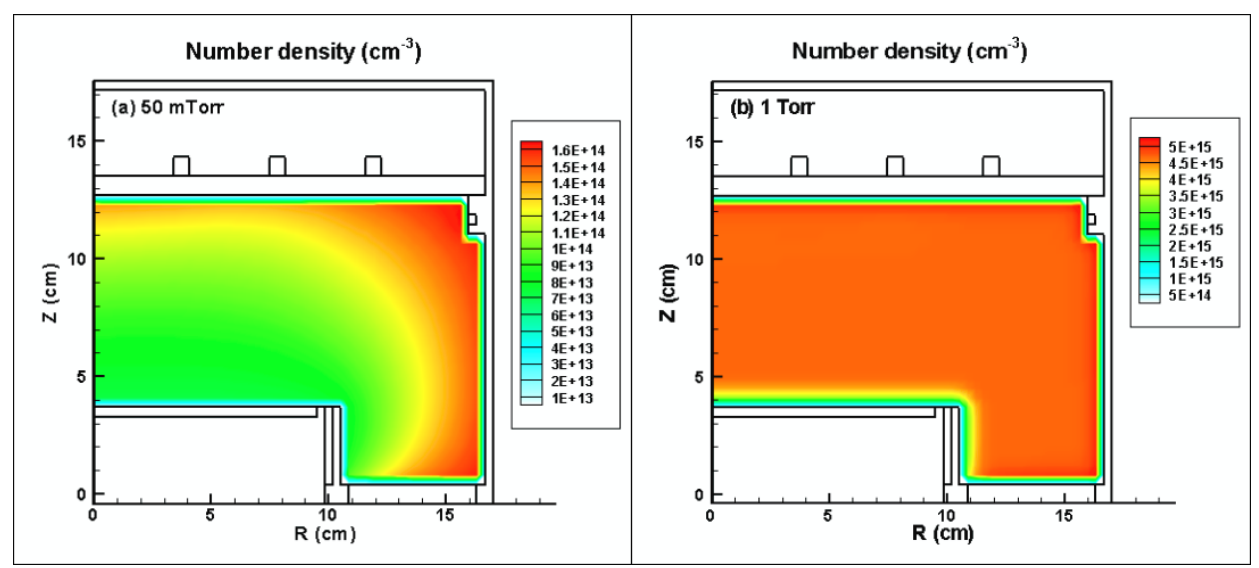

Figure 7 Calculated 2D number density of $\mathrm{CH}_{4}$ at the same conditions as in figure 3.

Similar density profiles are also observed for the other background gases (i.e. $\mathrm{C}_{2} \mathrm{H}_{2}, \mathrm{H}_{2}$ and $\mathrm{NH}_{3}$; not shown in the paper). In the discharge, several new species are formed by ionization, dissociation and other reactions as given in table 3-14. These species will be discussed in the next section.

\subsection{Plasma chemistry in the different gas mixtures}

To analyze the role of the plasma chemistry for CNT/CNF growth in an ICP-PECVD system, the volume-averaged densities of all plasma components are calculated for the four different gas mixtures at the two pressures under study. The results are shown in figures 8-11 for the $\mathrm{CH}_{4} / \mathrm{H}_{2}$ plasma, the $\mathrm{CH}_{4} / \mathrm{NH}_{3}$ plasma, the $\mathrm{C}_{2} \mathrm{H}_{2} / \mathrm{H}_{2}$ plasma, and the $\mathrm{C}_{2} \mathrm{H}_{2} / \mathrm{NH}_{3}$ plasma, respectively.
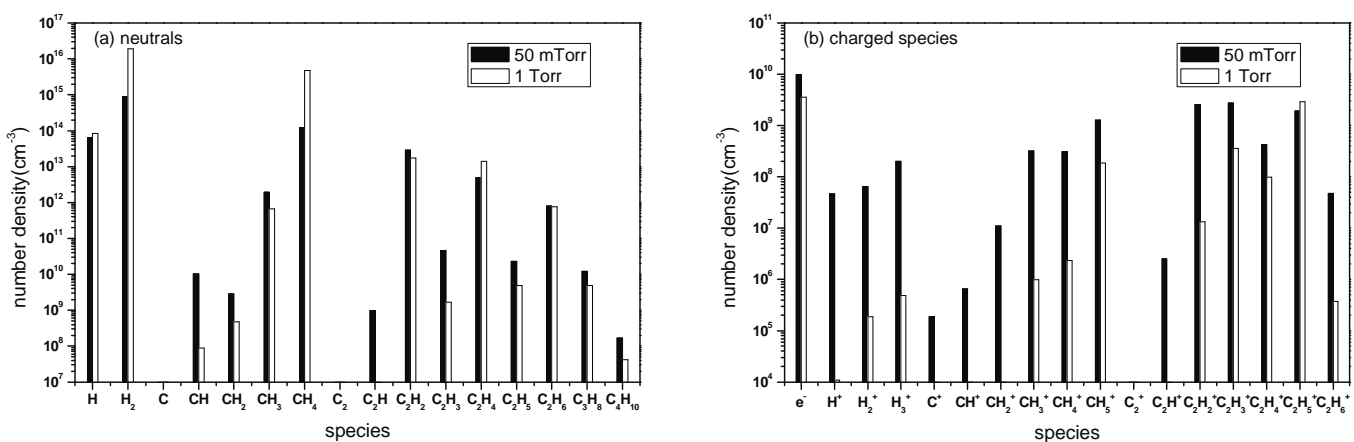

Figure 8. Calculated volume-averaged densities of (a) neutrals and (b) charged species for the $\mathrm{CH}_{4} / \mathrm{H}_{2}$ plasma at pressures of 50 mTorr and 1 Torr. The other parameters are the same as in figure 3 .

In the $\mathrm{CH}_{4} / \mathrm{H}_{2}$ plasma, it is clear that $\mathrm{H}_{2}, \mathrm{C}_{2} \mathrm{H}_{2}$ and $\mathrm{C}_{2} \mathrm{H}_{4}$ are the dominant molecules at both pressures, besides the feedstock gas $\mathrm{CH}_{4}$. This is consistent with the results measured by Denysenko et al. using mass spectrometry in the pressue range of 20 70 mTorr[30]. The primary radicals are $\mathrm{H}$ and $\mathrm{CH}_{3}$ at both pressures, which correlates well with the results of Oda et al.[29] At 50 mTorr, several ions are almost of equal importance, i.e., $\mathrm{C}_{2} \mathrm{H}_{\mathrm{x}}{ }^{+}(\mathrm{x}=2,3,4,5)$ and 
$\mathrm{CH}_{\mathrm{x}}{ }^{+}(\mathrm{x}=3,4,5)$, as well as $\mathrm{H}_{3}{ }^{+}$. In general, the ion densities are, however, five orders of magnitude lower than the neutrals densities, at 50 mTorr.

As the gas pressure increases to 1 Torr, the densities of $\mathrm{H}_{2}, \mathrm{CH}_{4}$ and $\mathrm{C}_{2} \mathrm{H}_{4}$ increase, but the density of $\mathrm{C}_{2} \mathrm{H}_{2}$ drops slightly. This is because the $\mathrm{C}_{2} \mathrm{H}_{2}$ molecules are mainly created by the following three reactions:

$$
\begin{aligned}
& \mathrm{C}_{2} \mathrm{H}_{4}+\mathrm{e}^{-} \rightarrow \mathrm{C}_{2} \mathrm{H}_{2}+\mathrm{H}_{2}+\mathrm{e}^{-}(5.8 \mathrm{eV}) \\
& \mathrm{CH}+\mathrm{CH}_{2} \rightarrow \mathrm{H}+\mathrm{C}_{2} \mathrm{H}_{2} \\
& \mathrm{CH}_{2}+\mathrm{CH}_{2} \rightarrow \mathrm{H}_{2}+\mathrm{C}_{2} \mathrm{H}_{2}
\end{aligned}
$$

Indeed, the densities of the radicals $\mathrm{CH}$ and $\mathrm{CH}_{2}$, as well as the electrons densities decrease at higher pressures. The pressure effect is even more pronounced for all ions (except $\mathrm{C}_{2} \mathrm{H}_{5}{ }^{+}$), which drop by one to three orders of magnitude. At the pressure of 1 Torr, $\mathrm{C}_{2} \mathrm{H}_{5}{ }^{+}$are the most important ions, followed by $\mathrm{CH}_{5}{ }^{+}, \mathrm{C}_{2} \mathrm{H}_{3}{ }^{+}$and $\mathrm{C}_{2} \mathrm{H}_{4}{ }^{+}$. This behavior is correlated to the increase of the $\mathrm{CH}_{4}$ and $\mathrm{C}_{2} \mathrm{H}_{4}$ densities. Indeed, these ions are mainly generated by reactions between small ions (such as $\mathrm{H}_{2}{ }^{+}, \mathrm{H}_{3}{ }^{+}, \mathrm{CH}_{2}{ }^{+}$and $\mathrm{CH}_{3}{ }^{+}$) and the molecules $\mathrm{CH}_{4}$ or $\mathrm{C}_{2} \mathrm{H}_{4}$ (see reactions 14, 18, 21, 22, 26, 28, 31, 34, 37 and 39 in Table 5). This also explains the significant drop in densities of $\mathrm{H}_{2}{ }^{+}, \mathrm{H}_{3}{ }^{+}, \mathrm{CH}_{2}{ }^{+}$and $\mathrm{CH}_{3}{ }^{+}$ions.

It is known that $\mathrm{CH}_{4}$ can hardly dissociate on the catalyst surface, whereas $\mathrm{C}_{2} \mathrm{H}_{2}, \mathrm{C}_{2} \mathrm{H}_{4}$ and $\mathrm{C}_{2} \mathrm{H}_{6}$ are characterized by a lower decomposition temperature[50]. Hence, because these molecules are also present in high densities in the $\mathrm{CH}_{4} / \mathrm{H}_{2}$ plasma, they will probably serve as carbon source for CNT/CNF growth. Moreover, as the hydrocarbon radicals are thought to be typical growth precursors for amorphous carbon thin films [52], a significant drop in their densities when increasing the pressure might indicate that a "cleaner" environment for CNT/CNF growth could be obtained. This might explain why a higher growth rate of CNT/CNF could be achieved at higher pressure[12].

When $\mathrm{NH}_{3}$ is diluted into the $\mathrm{CH}_{4}$ plasma instead of $\mathrm{H}_{2}$, the hydrocarbon species, such as $\mathrm{C}_{\mathrm{m}} \mathrm{H}_{\mathrm{n}}$ $(0 \leq \mathrm{m} \leq 3,0 \leq \mathrm{n} \leq 8)$ and $\mathrm{C}_{\mathrm{x}} \mathrm{H}_{\mathrm{y}}{ }^{+}$show similar trends as in the $\mathrm{CH}_{4} / \mathrm{H}_{2}$ plasma, i.e., the densities of the molecules $\mathrm{H}_{2}, \mathrm{CH}_{4}, \mathrm{C}_{2} \mathrm{H}_{4}$ and $\mathrm{C}_{2} \mathrm{H}_{6}$ increase with pressure, whereas the densities of most hydrocarbon radicals and ions show a decreasing trend. It is apparent that the densities of $\mathrm{H}_{2}$ and $\mathrm{H}$ reach the same value as in the case when hydrogen was used as the dilution gas. Indeed, these $\mathrm{H}_{2}$ molecules arise now mainly from the $\mathrm{NH}_{3}$ feedstock gas, by $\mathrm{H}$ abstraction reactions (see reaction 2 and 3 in Table 14) and the three body recombination reaction $\left(\mathrm{H}+\mathrm{H}+\mathrm{NH}_{3} \rightarrow \mathrm{H}_{2}+\right.$ $\mathrm{NH}_{3}$ ). As will be shown later, the ammonia is indeed highly decomposed in the plasma.

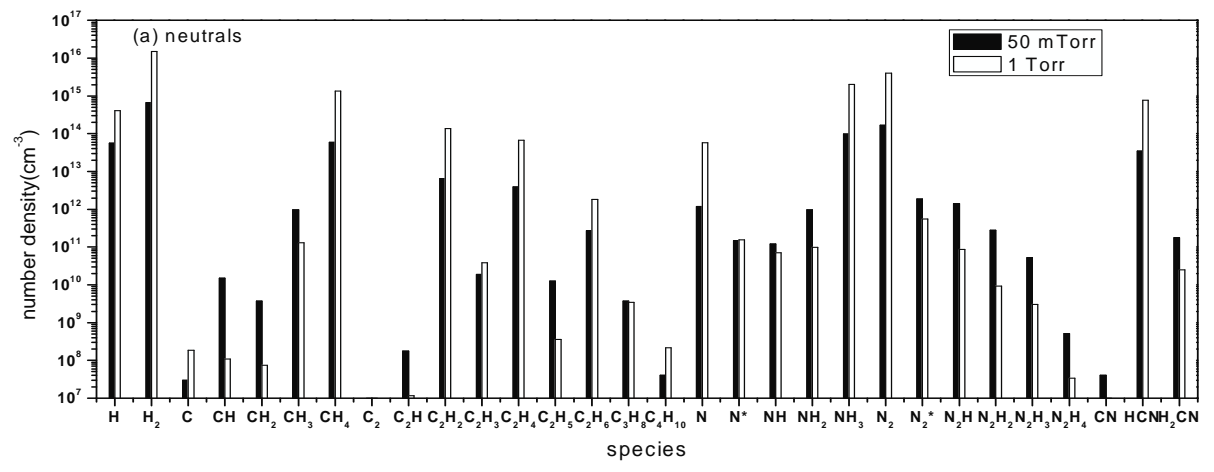




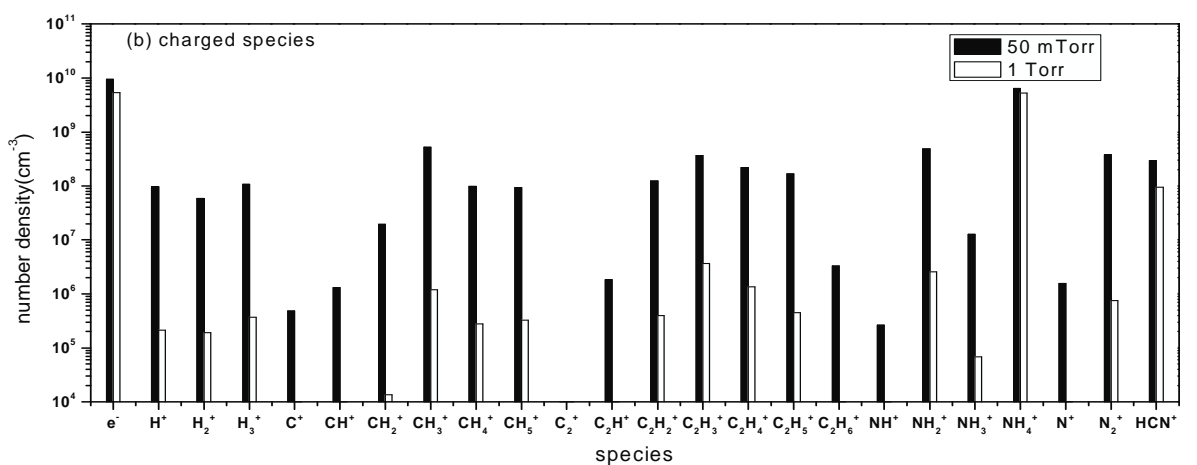

Figure 9 Calculated volume-averaged densities of (a) neutrals and (b) charged species for the $\mathrm{CH}_{4} / \mathrm{NH}_{3}$ plasma at pressures of 50 mTorr and 1 Torr. The other parameters are the same as in figure 3.

Moreover, the neutral species of $\mathrm{N}_{2}$ and $\mathrm{HCN}$, besides the $\mathrm{NH}_{3}$ feedstock gas, are observed at relatively high densities. This is consistent with the results reported by Bell et al. [13]. Indeed, $\mathrm{H}_{2}, \mathrm{~N}_{2}$ and $\mathrm{HCN}$ were detected as major neutral species when CNTs were synthesized in the $\mathrm{C}_{2} \mathrm{H}_{2} / \mathrm{NH}_{3}$ plasma. The role of $\mathrm{NH}_{3}$ was also discussed in that paper: it was stated to be a more effective source of atomic hydrogen compared with $\mathrm{H}_{2}$. Also from our calculations it is clear that $\mathrm{H}$ atoms are formed to a large extent when $\mathrm{NH}_{3}$ is used as the dilution gas (see figure $9 \mathrm{a}$ ). In addition, a significant amount of atomic nitrogen is also predicted by our model, and this activated nitrogen can also affect the growth kinetics of CNT/CNF at the catalyst surface[53]. Finally, the $\mathrm{NH}_{4}{ }^{+}$ions are found to be the dominant ions, which agree well with the simulation results of Hash et al. [26, 27].
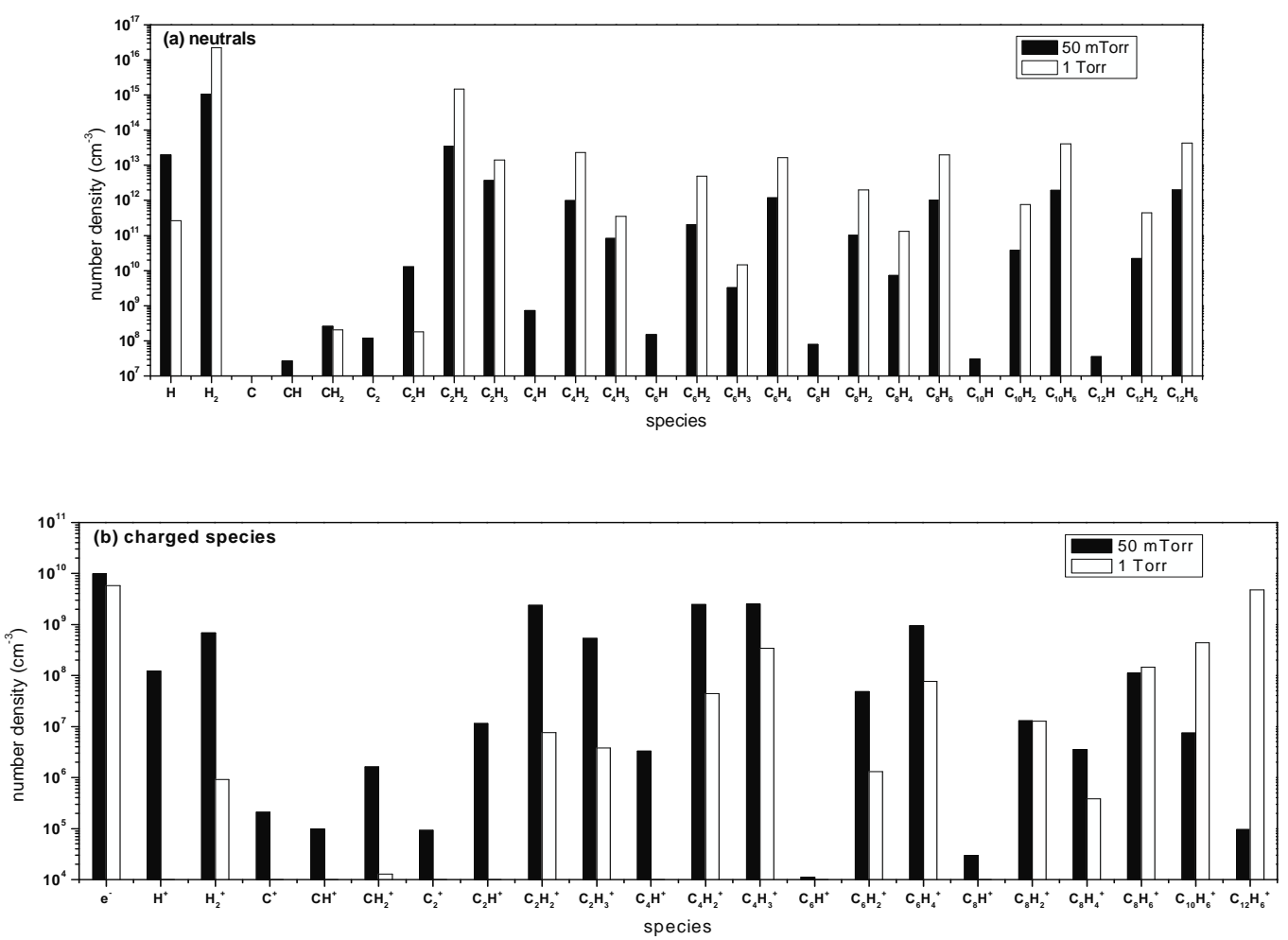

Figure 10 Calculated volume-averaged densities of (a) neutrals and (b) charged species for the $\mathrm{C}_{2} \mathrm{H}_{2} / \mathrm{H}_{2}$ plasma at pressures of 50 mTorr and 1 Torr. The other parameters are the same as in figure 3.

In the acetylene/hydrogen plasma (see figure 10), long-chain hydrocarbons such as $\mathrm{C}_{2 \mathrm{n}} \mathrm{H}_{2}$ and $\mathrm{C}_{2 \mathrm{n}} \mathrm{H}_{6}(\mathrm{n}=4, \ldots, 6)$ are formed in the discharge, and become important for both pressures. This has been reported also by Wei [25] using mass spectrometry, and it was stated that they poisoned the catalyst and prevented the growth of $\mathrm{CNFs}[25]$ The major ions are $\mathrm{C}_{2} \mathrm{H}_{2}{ }^{+}, \mathrm{C}_{4} \mathrm{H}_{2}{ }^{+}, \mathrm{C}_{4} \mathrm{H}_{3}{ }^{+}$, and 
$\mathrm{C}_{6} \mathrm{H}_{4}{ }^{+}$at low pressure. At the pressure of 1 Torr, the $\mathrm{C}_{2 \mathrm{n}} \mathrm{H}_{6}{ }^{+}(\mathrm{n}=4, \ldots, 6)$ ions become predominant. Indeed, these heavy ions are primarily created from $\mathrm{C}_{2} \mathrm{H}_{2}$ insertion reactions (see 24-27 in Table 9). These heavy ions will probably enhance the physical sputtering on the surface of the catalyst to remove the amorphous $\mathrm{C}$ film. In addition, these energetic ions may weaken the adhesion of catalyst particles, leading to the tip growth mode during the CNF formation[50].
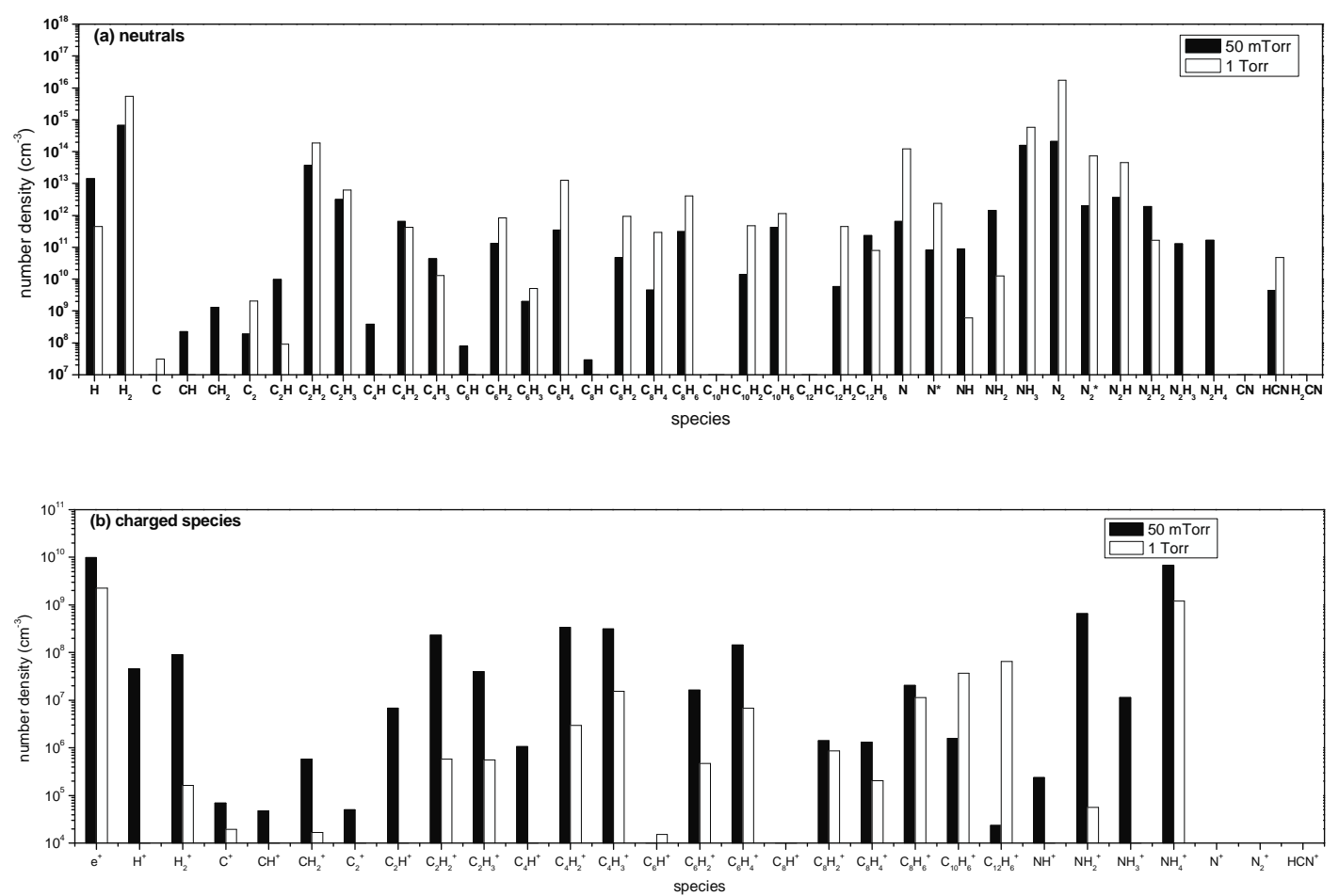

Figure 11 Calculated volume-averaged densities of (a) neutrals and (b) charged species for the $\mathrm{C}_{2} \mathrm{H}_{2} / \mathrm{NH}_{3}$ plasma at pressures of 50 mTorr and 1 Torr. The other parameters are the same as in figure 3 .

In the $\mathrm{C}_{2} \mathrm{H}_{2} / \mathrm{NH}_{3}$ discharge, on the other hand, the formation of long chain hydrocarbons is less important, as is clear from figure $11 . \mathrm{N}_{2}$ and $\mathrm{NH}_{4}{ }^{+}$are the predominant neutrals and ions, respectively. Compared with the $\mathrm{CH}_{4} / \mathrm{NH}_{3}$ plasma, the densities of $\mathrm{H}$ and $\mathrm{H}_{2}$ are reduced with one order of magnitude, and more striking is the drop in $\mathrm{H}$ density upon pressure increase, which is opposite to the behavior in the $\mathrm{CH}_{4} / \mathrm{NH}_{3}$ plasma (see above). The atomic hydrogen is commonly accepted as an etchant during the CNT/CNF growth. The decrease in density of $\mathrm{H}$ would reduce the etching effect in $\mathrm{CNT} / \mathrm{CNF}$ growth, resulting in the enhanced CNT/CNF growth[54].

In general, we can see that atomic carbon is hardly formed in the plasma, for the four gas mixtures under study at two different gas pressures. Therefore we can conclude that the carbon sources for CNT/CNF growth mainly arise from decomposition of hydrocarbon molecules on the catalyst surface, as is also stated in [55].

To examine the conversion of the background gases, the decomposition rate (DR) is defined as follows

$$
\mathrm{DR}=1-\frac{\text { volume-averaged density of background gas }}{\text { density of background gas at inlet }}
$$

The calculated results for the four different gas mixtures at the two different pressures are shown in Table 16.

It is clear from the table that the background $\mathrm{CH}_{4} / \mathrm{C}_{2} \mathrm{H}_{2}$ gases have a higher DR (more than $71 \%$ ) when ammonia is used as the dilution gas. Moreover, the ammonia itself also almost fully converted (more than 83\%), which was also observed in [26]. Compared to the ammonia 
dilution, the hydrogen has almost no decomposition (around 0.2 9\% in the case of $\mathrm{CH}_{4}$ and even negative values in the case of $\mathrm{C}_{2} \mathrm{H}_{2}$ ). These negative values mean that more background gas species are formed than decomposed. Indeed, the threshold energy needed for the dissociation of $\mathrm{CH}_{4} / \mathrm{C}_{2} \mathrm{H}_{2}(8.8 / 7.5 \mathrm{eV})$ is slightly lower than that for $\mathrm{H}_{2}(8.87 \mathrm{eV})$. Hence, $\mathrm{H}_{2}$ can be formed due to dissociation of $\mathrm{CH}_{4} / \mathrm{C}_{2} \mathrm{H}_{2}$, followed by recombination of the resulting $\mathrm{H}$ atoms into $\mathrm{H}_{2}$. As far as the pressure effects are concerned, the background gas $\mathrm{CH}_{4}$ has more or less the same DR in case of ammonia dilution, and $\mathrm{C}_{2} \mathrm{H}_{2}$ has a slightly higher DR at the pressure of 1 Torr compared to 50 mTorr when ammonia is used as the dilution gas. However when hydrogen is the dilution gas, a significantly lower DR of the background gases was observed at the higher pressure. This is most striking for the $\mathrm{CH}_{4} / \mathrm{H}_{2}$ plasma, where the DR of $\mathrm{CH}_{4}$ drops from almost $50 \%$ at 50 mTorr to $3 \%$ at 1 Torr. Because $\mathrm{CH}_{4}$ can hardly dissociate on the catalyst surface [50], this would suggest that the carbon source for CNT growth is very small in the $\mathrm{CH}_{4} / \mathrm{H}_{2}$ plasma at the moderate pressure range of around 1 Torr. This might be correlated with literature [20,21] where such conditions were found to be favourable for the formation of SWCNT.

\section{Conclusions}

An ICP reactor operating in four different gas mixtures and at two pressures in the range typically used for CNT/CNF growth was investigated by means of hybrid plasma simulations.

The feedstock hydrocarbon source gases were decomposed in the plasma, generating small and reactive ions and neutrals. The latter can reach the substrate to provide the carbon sources for $\mathrm{CNT} / \mathrm{CNF}$ growth.

It was found that in methane containing plasmas the radicals $\mathrm{H}$ and $\mathrm{CH}_{3}$ are the primary radicals, $\mathrm{C}_{2} \mathrm{H}_{2}$ and $\mathrm{C}_{2} \mathrm{H}_{4}$ (and $\mathrm{N}_{2}$ and $\mathrm{HCN}$ in case of ammonia dilution) are the dominant molecules besides the feedstock gases $\left(\mathrm{H}_{2} / \mathrm{NH}_{3}\right.$ and $\left.\mathrm{CH}_{4}\right)$. Several ions, i.e., $\mathrm{CH}_{\mathrm{x}}{ }^{+}(\mathrm{x}=3,4,5)$ and $\mathrm{C}_{2} \mathrm{H}_{\mathrm{x}}{ }^{+}$ $(\mathrm{x}=2,3,4,5)$, are of comparable importance. The densities of the molecules increase with pressure, while the radical and ion densities become lower at higher pressures. Our results suggest that $\mathrm{C}_{2} \mathrm{H}_{2}$ and $\mathrm{C}_{2} \mathrm{H}_{4}$ are the main precursors for $\mathrm{CNT} / \mathrm{CNF}$ growth in methane containing plasmas.

On the other hand in acetylene containing plasma, the long chain species (both neutrals and ions) are predominant. The latter will enhance the physical sputtering and it can therefore be expected that they can effectively remove amorphous $\mathrm{C}$ films on the catalyst particles. Therefore, these long chain species probably play a key role in the formation of CNTs/CNFs.

When ammonia was used as the dilution gas, the trends of hydrocarbon species were found similar as in the $\mathrm{H}_{2}$-dilution plasmas, but the $\mathrm{N}_{2}$ and $\mathrm{NH}_{4}{ }^{+}$species became the dominant neutrals and ions, respectively. A significant amount of atomic nitrogen was also predicted in our model, and these reactive nitrogen species can also affect the growth kinetics of CNTs/CNFs at the catalyst surface.

Our simulations suggest that, under the investigated operating conditions, a high DR of the hydrocarbon feedstock gases (either $\mathrm{CH}_{4}$ or $\mathrm{C}_{2} \mathrm{H}_{2}$ ) can be achieved when $\mathrm{NH}_{3}$ is used as the dilution gas, for both low and moderate pressure, as well as in the case of $\mathrm{H}_{2}$ dilution at low pressure. However, at the moderate pressure of 1 Torr, the DR of $\mathrm{CH}_{4}$ is very low in the case of $\mathrm{H}_{2}$ dilution. Because $\mathrm{CH}_{4}$ cannot easily be dissociated at the catalyst surface, this suggests that the carbon source for CNT formation is rather limited, which could correspond to conditions favorable for SWCNT growth, as is indeed observed in literature [20, 21].

In all cases investigated, the density of atomic carbon in the plasma is found to be very low; hence the C-supply for the CNT/CNF growth needs to come from decomposition of hydrocarbon species at the catalyst surface itself, as is also generally stated in literature[55]. The detailed behavior of the hydrocarbon species at the catalyst surface is not yet taken into account in our model. Indeed, our model only provides insight in the most important plasma species present in the discharge, which might play a role for the CNT growth. However, in future work, we would like to combine our plasma chemistry model, providing the fluxes of the most important plasma species to the substrate, with a model describing the surface processes on the catalyst nanoparticles, in order to obtain a comprehensive picture of the catalytic growth of CNTs. 


\section{Acknowledgements}

We would like to thank the Fund for Scientific Research (FWO Flanders) and the Prime Minister's Office through IUAP-VI for financial support as well as the CalcUA computing facilities of the University of Antwerp. We are also very grateful to M. Kushner and group members for providing the HPEM and useful advice. 


\section{References}

[1] Iijima S 1991 Nature 354 56-8.

[2] Tseng G Y and Ellenbogen J C 2001 Science 294 1293-4.

[3] Darkrim F L, Malbrunot P and Tartaglia G P 2002 International Journal of Hydrogen Energy 27 193-202.

[4] Guillorn M A, Melechko A V, Merkulov V I, Ellis E D, Simpson M L, Baylor L R and Bordonaro G J 2001 Journal of Vacuum Science \& Technology B 19 2598-601.

[5] Meyyappan M, Delzeit L, Cassell A and Hash D 2003 Plasma Sources Science \& Technology 12 205-16.

[6] Journet C, Maser W K, Bernier P, Loiseau A, delaChapelle M L, Lefrant S, Deniard P, Lee R and Fischer J E 1997 Nature 388 756-8.

[7] Yudasaka M, Komatsu T, Ichihashi T and Iijima S 1997 Chemical Physics Letters 278 102-6.

[8] Lee C J, Kim D W, Lee T J, Choi Y C, Park Y S, Lee Y H, Choi W B, Lee N S, Park G S and Kim J M 1999 Chemical Physics Letters 312 461-8.

[9] Cui H, Zhou O and Stoner B R 2000 J Appl Phys 88 6072-4.

[10] Bower C, Zhu W, Jin S H and Zhou O 2000 Appl Phys Lett 77 830-2.

[11] Gulas M, Le Normand F and Veis P 2009 Applied Surface Science 255 5177-80.

[12] Chhowalla M, Teo K B K, Ducati C, Rupesinghe N L, Amaratunga G A J, Ferrari A C, Roy D, Robertson J and Milne W I 2001 J Appl Phys 90 5308-17.

[13] Bell M S, Lacerda R G, Teo K B K, Rupesinghe N L, Amaratunga G A J, Milne W I and Chhowalla M 2004 Appl Phys Lett 85 1137-9.

[14] Hofmann S, Ducati C, Robertson J and Kleinsorge B 2003 Applied Physics Letters 83 135-7.

[15] Okita A, Suda Y, Oda A, Nakamura J, Ozeki A, Bhattacharyya K, Sugawara H and Sakai Y 2007 Carbon 45 1518-26.

[16] Hiramatsu M, Shiji K, Amano H and Hori M 2004 Applied Physics Letters 84 4708-10.

[17] Delzeit L, McAninch I, Cruden B A, Hash D, Chen B, Han J and Meyyappan M 2002 J Appl Phys 91 6027-33.

[18] Cruden B A and Meyyappan M 2005 J Appl Phys 97 084311--15.

[19] Matthews K, Cruden B A, Chen B, Meyyappan M and Delzeit L 2002 J Nanosci Nanotechno 2 475-80.

[20] Weng C H, Yang C S, Lin H, Tsai C H and Leou K C 2008 Journal of Nanoscience and Nanotechnology 8 2526-33.

[21] Yang C S 2005 Low temperature growth of single-walled carbon nanotubes by PECVD. In: Department of Engineering and System Science, (Hsinchu, Taiwan: National Tsing Hua University) p 88.

[22] Ostrikov K, Tsakadze Z, Rutkevych P P, Long J D, Xu S and Denysenko I 2005 Contributions to Plasma Physics 45 514-21.

[23] Caughman J B O, Baylor L R, Guillorn M A, Merkulov V I, Lowndes D H and Allard L F 2003 Appl Phys Lett 83 1207-9.

[24] Lin Y Y, Wei H W, Leou K C, Lin H, Tung C H, Wei M T, Lin C and Tsai C H 2006 J Vac Sci Technol B 24 97-103.

[25] Wei H W 2008 study of growth of vertically-aligned carbon nanofibers by plasma enhanced chemical vapor deposition growth mechanism and field emission characterization. In: Department of Engineering and System Science, (Hsinchu, Taiwan: National Tsing Hua University) p 175.

[26] Hash D, Bose D, Govindan T R and Meyyappan M 2003 J Appl Phys 93 6284-90.

[27] Hash D B, Bell M S, Teo K B K, Cruden B A, Milne W I and Meyyappan M 2005 Nanotechnology 16 925-30.

[28] Okita A, Suda Y, Ozeki A, Sugawara H, Sakai Y, Oda A and Nakamura J 2006 J Appl Phys 99 0143021-7.

[29] Oda A, Suda Y and Okita A 2008 Thin Solid Films 516 6570-4.

[30] Denysenko I B, Xu S, Long J D, Rutkevych P P, Azarenkov N A and Ostrikov K 2004 J Appl Phys 95 2713-24.

[31] Ostrikov K, Yoon H J, Rider A E and Vladimirov S V 2007 Plasma Process Polym 4 27-40.

[32] Teo K B K, Lacerda R G, Yang M H, Teh A S, Robinson L A W, Dalal S H, Rupesinghe N L, Chhowalla M, Lee S B, Jefferson D A, Hasko D G, Amaratunga G A J, Milne W L, Legagneux P, Gangloff L, Minoux E, Schnell J P and Pribat D 2004 Iee Proceedings-Circuits Devices and Systems 151 443-51.

[33] Koohsorkhi J, Hoseinzadegan H, Mohajerzadeh S, Soleimani E A, Koohsorkhi J and Arzi E 2005 Fullerenes Nanotubes and Carbon Nanostructures 13 355-64. 
[34] Shimoi N and Tanaka S 2008 Journal of Ceramic Processing Research 9 437-9.

[35] Cassell A M, Ye Q, Cruden B A, Li J, Sarrazin P C, Ng H T, Han J and Meyyappan M 2004 Nanotechnology 15 9-15.

[36] Meyyappan M 2009 J Phys D Appl Phys 42 213001-15.

[37] Ventzek P L G, Sommerer T J, Hoekstra R J and Kushner M J 1993 Appl Phys Lett 63 605-7.

[38] Collison W Z and Kushner M J 1996 Appl Phys Lett 68 903-5.

[39] Kushner M J, Collison W Z, Grapperhaus M J, Holland J P and Barnes M S 1996 J Appl Phys 80 1337-44.

[40] Grapperhaus M J and Kushner M J 1997 J Appl Phys 81 569-77.

[41] Rauf S and Kushner M J 1997 J Appl Phys 81 5966-74.

[42] Kinder R L and Kushner M J 2001 J Vac Sci Technol A 19 76-86.

[43] Kushner M J 2009 J Phys D Appl Phys 42 194013--20.

[44] Herrebout D, Bogaerts A, Yan M, Gijbels R, Goedheer W and Vanhulsel A 2002 J Appl Phys 92 2290-5.

[45] Deschenaux C, Affolter A, Magni D, Hollenstein C and Fayet P 1999 J Phys D Appl Phys 32 1876-86.

[46] De Bleecker K, Bogaerts A and Goedheer W 2006 Physical Review E 73 026405--16.

[47] Mao M, Benedikt J, Consoli A and Bogaerts A 2008 J Phys D Appl Phys 41 225201--14.

[48] Thomson G M, Schummer.Jh, James D R, Graham E, Gatland I R, Flannery M R and Mcdaniel E W 1973 J Chem Phys 58 2402-11.

[49] Ervin K M, Ho J and Lineberger W C 1989 J Chem Phys 91 5974-92.

[50] Hash D B and Meyyappan M 2003 J Appl Phys 93 750-2.

[51] Naha S and Puri I K 2008 J Phys D Appl Phys 41 -.

[52] Bera K, Farouk B and Vitello P 2001 J Phys D Appl Phys 34 1479-90.

[53] Jung M J, Eun K Y, Baik Y J, Lee K R, Shin J K and Kim S T 2001 Thin Solid Films 398 1505.

[54] Lee T Y, Han J H, Choi S H, Yoo J B, Park C Y, Jung T, Yu S, Yi W K, Han I T and Kim J M 2003 Diam Relat Mater 12 851-5.

[55] Hofmann S, Sharma R, Ducati C, Du G, Mattevi C, Cepek C, Cantoro M, Pisana S, Parvez A, Cervantes-Sodi F, Ferrari A C, Dunin-Borkowski R, Lizzit S, Petaccia L, Goldoni A and Robertson J 2007 Nano Lett 7 602-8.

[56] Hayashi M 1979 J Phys-Paris 40 45-6.

[57] Kline L E 1982 Ieee T Plasma Sci 10 224-33.

[58] Sohn W, Kochen K H, Scheuerlein K M, Jung K and Ehrhardt H 1986 Journal of Physics B: Atomic and Molecular Optical Physics 19 3625-32.

[59] Tanaka H, Kubo M, Onodera N and Suzuki A 1983 J Phys B-at Mol Opt 16 2861-9.

[60] Winters H F 1975 J Chem Phys 63 3462-6.

[61] Chatham H, Hils D, Robertson R and Gallagher A 1984 The Journal of Chemical Physics 81 1770-7.

[62] Reiter R K J a D 2002 FZJ Report Juel-3966

[63] Reiter R K J a D 2002 FZJ Report Juel-4005

[64] Tawara H, Itikawa Y, Nishimura H, Tanaka H and Nakamura Y 1992 Nucl Fusion 2 41-64.

[65] Tian C C and Vidal C R 1998 J Phys B-at Mol Opt 31 895-909.

[66] UMIST http://www.udfa.net/

[67] Herrebout D, Bogaerts A, Yan M, Gijbels R, Goedheer W and Dekempeneer E $2001 \mathrm{~J}$ Appl Phys 90 570-9.

[68] Morrison N A, William C and Milne W I 2003 J Appl Phys 94 7031-43.

[69] http://physics.nist.gov/PhysRefData/Ionization/molTable.html.

[70] Laufer A H and Fahr A 2004 Chem Rev 104 2813-32.

[71] Wang H and Frenklach M 1997 Combust Flame 110 173-221.

[72] Masi M, Cavallotti C and Carra S 1998 Chem Eng Sci 53 3875-86.

[73] Frenklach M and Warnatz J 1987 Combust Sci Technol 51 265-83.

[74] Landera A, Krishtal S P, Kislov V V, Mebel A M and Kaiser R I 2008 J Chem Phys 128 -.

[75] Hayashi M 1990 Nato Adv Sci I B-Phy 220 333-40.

[76] Hack W and Wagner H G 1994 Ber Bunsen Phys Chem 98 156-64.

[77] Thielen K and Roth P 1986 Aiaa J 24 1102-5.

[78] Corchado J C and EspinosaGarcia J 1997 J Chem Phys 106 4013-21.

[79] Sommerer T J and Kushner M J 1992 J Appl Phys 71 1654-73.

[80] Rohrig M and Wagner H G 1994 Ber Bunsen Phys Chem 98 858-63.

[81] Kushner M J 1992 J Appl Phys 71 4173-89. 
[82] Stothard N, Humpfer R and Grotheer H H 1995 Chem Phys Lett 240 474-80.

[83] Xu Z F, Fang D C and Fu X Y 1998 Int J Quantum Chem 70 321-9.

[84] Pagsberg P B, Eriksen J and Christensen H C 1979 J Phys Chem-Us 83 582-90.

[85] Meaburn G M and Gordon S 1968 J Phys Chem-Us 72 1592-\&.

[86] Nicholas J E, Spiers A I and Martin N A 1986 Plasma Chem Plasma P 6 39-51.

[87] Xu Z F, Fang D C and Fu X Y 1997 Chem Phys Lett 275 386-91.

[88] Yoshimura M, Tamura F, Koshi M and Matsui H 1990 Nippon Kagaku Kaishi 589-93.

[89] Teng L and Winkler C A 1973 Can J Chem 51 3771-3.

[90] Linder D P, Duan X F and Page M 1996 J Chem Phys 104 6298-307.

[91] Gehring M, Hoyerman.K, Wagner H G and Wolfrum J 1971 Berich Bunsen Gesell 75 1287$\&$.

[92] Schiavello M and Volpi G G 1962 J Chem Phys 37 1510-\&.

[93] Stief L J 1970 J Chem Phys 52 4841-\&.

[94] Vaghjiani G L 1995 Int J Chem Kinet 27 777-90.

[95] Dorai R and Kushner M J 2003 J Phys D Appl Phys 36 666-85.

[96] Legrand J C, Diamy A M, Hrach R and Hrachova V 1998 Vacuum 50 491-5.

[97] Legrand J C, Diamy A M, Hrach R and Hrachova V 1997 Vacuum 48 671-5.

[98] Okita A, Suda Y, Ozeki A, Sugawara H, Sakai Y, Oda A and Nakamura J 2006 J Appl Phys 99 -.

[99] Naujoks D, Bohmeyer W, Markin A, Arkhipov I, Carl P, Koch B, Reiner H D, Schroder D and Fussmann G 2004 Phys Scripta T111 80-5.

[100] Liu D P, Martin I T, Zhou J and Fisher E R 2006 Pure Appl Chem 78 1187-202. 


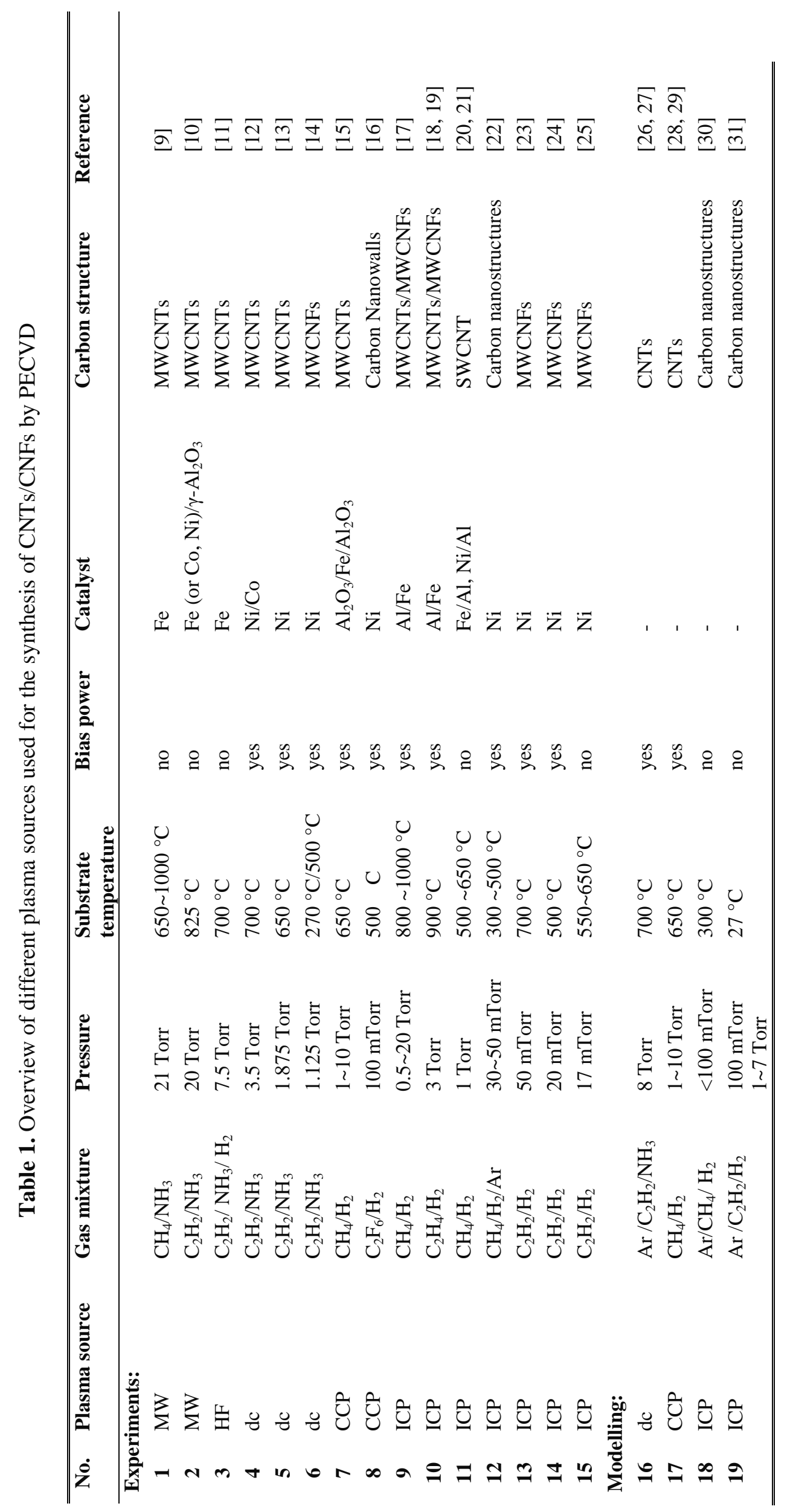




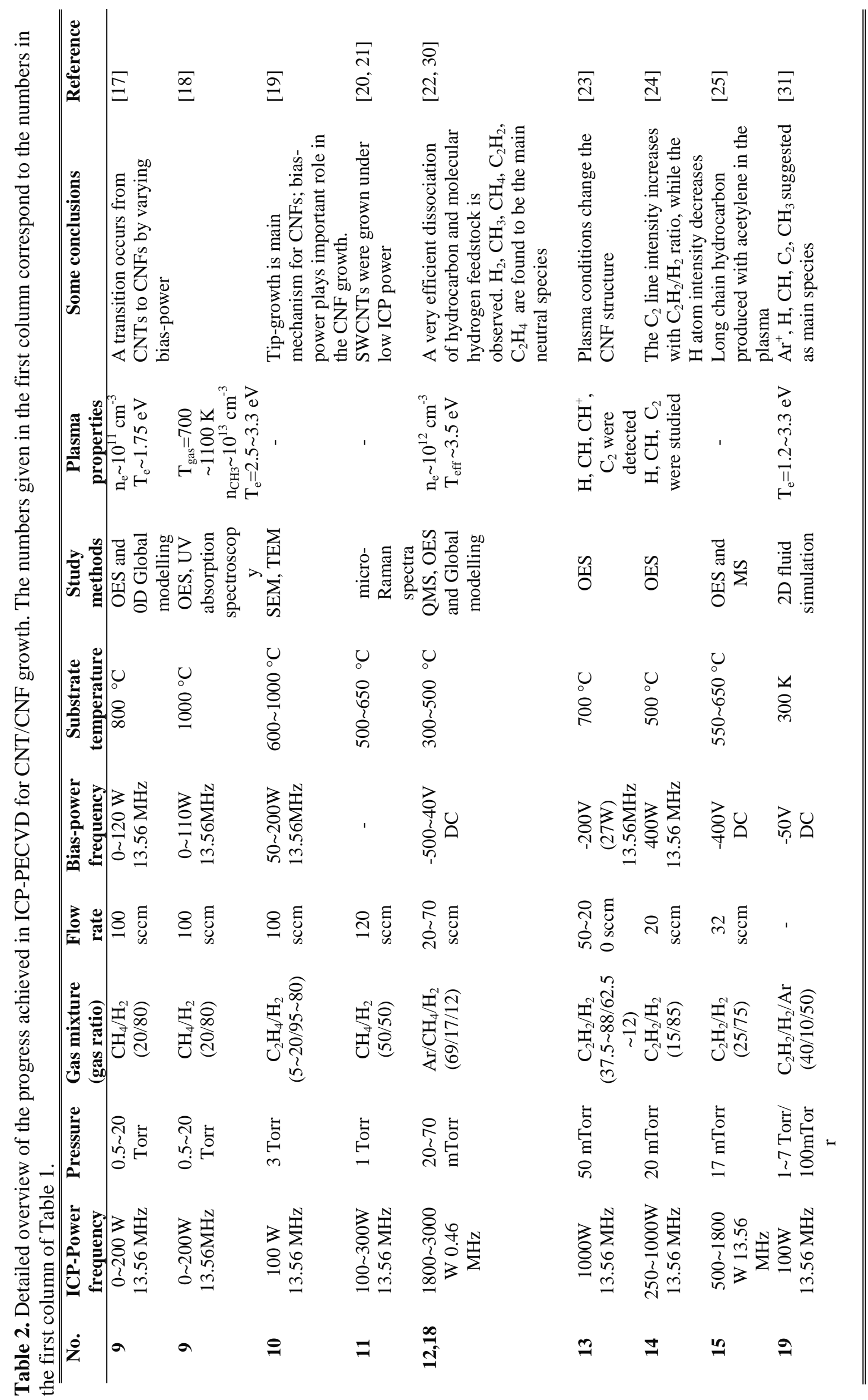


Table 3. Different species considered in the $\mathrm{CH}_{4} / \mathrm{H}_{2}$ model, besides electrons

\begin{tabular}{ccc}
\hline \hline Molecules & Ions & Radicals \\
\hline $\mathrm{H}_{2}$ & $\mathrm{H}^{+}, \mathrm{H}_{2}{ }^{+}, \mathrm{H}_{3}{ }^{+}$ & $\mathrm{H}$ \\
$\mathrm{CH}_{4}$ & $\mathrm{C}^{+}, \mathrm{CH}^{+}, \mathrm{CH}_{2}{ }^{+}, \mathrm{CH}_{3}{ }^{+}$, & $\mathrm{C}, \mathrm{CH}, \mathrm{CH}_{2}, \mathrm{CH}_{3}$ \\
& $\mathrm{CH}_{4}{ }^{+}, \mathrm{CH}_{5}{ }^{+}$ & \\
$\mathrm{C}_{2} \mathrm{H}_{2}, \mathrm{C}_{2} \mathrm{H}_{4}, \mathrm{C}_{2} \mathrm{H}_{6}$ & $\mathrm{C}_{2}{ }^{+}, \mathrm{C}_{2} \mathrm{H}^{+}, \mathrm{C}_{2} \mathrm{H}_{2}{ }^{+}, \mathrm{C}_{2} \mathrm{H}_{3}{ }^{+}$, & \\
& $\mathrm{C}_{2} \mathrm{H}_{4}^{+}, \mathrm{C}_{2} \mathrm{H}_{5}^{+}, \mathrm{C}_{2} \mathrm{H}_{6}^{+}$ & $\mathrm{C}_{2}, \mathrm{C}_{2} \mathrm{H}, \mathrm{C}_{2} \mathrm{H}_{3}, \mathrm{C}_{2} \mathrm{H}_{5}$ \\
$\mathrm{C}_{3} \mathrm{H}_{8}, \mathrm{C}_{4} \mathrm{H}_{10}$ & & \\
& & \\
\hline
\end{tabular}


Table 4. Electron impact collisions included in the $\mathrm{CH}_{4} / \mathrm{H}_{2}$ model and their corresponding threshold energies, and references where the cross sections were adopted from.

\begin{tabular}{|c|c|c|c|c|}
\hline No & Reaction & $\begin{array}{l}\text { Threshold } \\
\text { Energy }(\mathrm{eV})\end{array}$ & Reaction Type & Reference \\
\hline & $\mathbf{H}_{2}$ & & & \\
\hline 1 & $\mathrm{e}^{-}+\mathrm{H}_{2} \rightarrow \mathrm{H}_{2}+\mathrm{e}^{-}$ & 0.0 & Momentum transfer & {$[56]$} \\
\hline 2 & $\mathrm{e}^{-}+\mathrm{H}_{2}{ }^{(\mathrm{j}=0)} \rightarrow \mathrm{H}_{2}{ }^{(\mathrm{j}=2)}+\mathrm{e}^{-}$ & 0.044 & Rotational excitation & [56] \\
\hline 3 & $\mathrm{e}^{-}+\mathrm{H}_{2}{ }^{(\mathrm{j}=1)} \rightarrow \mathrm{H}_{2}{ }^{(\mathrm{j}=3)}+\mathrm{e}^{-}$ & 0.073 & Rotational excitation & {$[56]$} \\
\hline 4 & $\mathrm{e}^{-}+\mathrm{H}_{2}{ }^{(\mathrm{v}=0)} \rightarrow \mathrm{H}_{2}{ }^{(\mathrm{v}=1)}+\mathrm{e}^{-}$ & 0.516 & Vibrational excitation & {$[56]$} \\
\hline 5 & $\mathrm{e}^{-}+\mathrm{H}_{2}{ }^{(\mathrm{v}=0)} \rightarrow \mathrm{H}_{2}{ }^{(\mathrm{v}=2)}+\mathrm{e}^{-}$ & 1.000 & Vibrational excitation & {$[56]$} \\
\hline 6 & $\mathrm{e}^{-}+\mathrm{H}_{2}{ }^{(\mathrm{v}=0)} \rightarrow \mathrm{H}_{2}{ }^{(\mathrm{v}=3)}+\mathrm{e}^{-}$ & 1.500 & Vibrational excitation & {$[56]$} \\
\hline 7 & $\mathrm{e}^{-}+\mathrm{H}_{2} \rightarrow \mathrm{H}_{2}(\mathrm{~b} 3)+\mathrm{e}^{-}$ & 8.900 & Electronic excitation & [56] \\
\hline 8 & $\mathrm{e}^{-}+\mathrm{H}_{2} \rightarrow \mathrm{H}_{2}(\mathrm{~B} 1)+\mathrm{e}^{-}$ & 11.300 & Electronic excitation & [56] \\
\hline 9 & $\mathrm{e}^{-}+\mathrm{H}_{2} \rightarrow \mathrm{H}_{2}(\mathrm{c} 3)+\mathrm{e}^{-}$ & 11.75 & Electronic excitation & [56] \\
\hline 10 & $\mathrm{e}^{-}+\mathrm{H}_{2} \rightarrow \mathrm{H}_{2}(\mathrm{a} 3)+\mathrm{e}^{-}$ & 11.800 & Electronic excitation & [56] \\
\hline 11 & $\mathrm{e}^{-}+\mathrm{H}_{2} \rightarrow \mathrm{H}_{2}(\mathrm{C} 1)+\mathrm{e}^{-}$ & 12.400 & Electronic excitation & [56] \\
\hline 12 & $\mathrm{e}^{-}+\mathrm{H}_{2} \rightarrow \mathrm{H}_{2}(\mathrm{~d} 3)+\mathrm{e}^{-}$ & 14.000 & Electronic excitation & {$[56]$} \\
\hline 13 & $\mathrm{e}^{-}+\mathrm{H}_{2} \rightarrow \mathrm{H}+\mathrm{H}+\mathrm{e}^{-}$ & 8.870 & Dissociation & [56] \\
\hline 14 & $\mathrm{e}^{-}+\mathrm{H}_{2} \rightarrow \mathrm{H}_{2}^{+}+2 \mathrm{e}^{-}$ & 15.400 & Ionization & [56] \\
\hline 15 & $\begin{array}{l}\mathrm{e}^{-}+\mathrm{H}_{2}^{+} \rightarrow \mathrm{H}+\mathrm{H} \\
\mathbf{C H}_{4}\end{array}$ & 0.0 & Recombination & {$[57]$} \\
\hline 16 & $\mathrm{e}^{-}+\mathrm{CH}_{4} \rightarrow \mathrm{CH}_{4}+\mathrm{e}^{-}$ & 0.000 & Momentum transfer & {$[58,59]$} \\
\hline 17 & $\mathrm{e}^{-}+\mathrm{CH}_{4}{ }^{(\mathrm{v}=1)} \rightarrow \mathrm{CH}_{4}{ }^{(\mathrm{v}=3)}+\mathrm{e}^{-}$ & 0.3839 & Vibrational excitation & {$[58,59]$} \\
\hline 18 & $\mathrm{e}^{-}+\mathrm{CH}_{4}{ }^{(\mathrm{v}=2)}+\mathrm{e}^{-} \rightarrow \mathrm{CH}_{4}{ }^{(\mathrm{v}=4)}+\mathrm{e}^{-}$ & 0.1649 & Vibrational excitation & {$[58,59]$} \\
\hline 19 & $\mathrm{e}^{-}+\mathrm{CH}_{4} \rightarrow \mathrm{CH}_{3}+\mathrm{H}+\mathrm{e}^{-}$ & 8.800 & Dissociation & {$[60]$} \\
\hline 20 & $\mathrm{e}^{-}+\mathrm{CH}_{4} \rightarrow \mathrm{CH}_{2}+\mathrm{H}_{2}+\mathrm{e}^{-}$ & 9.400 & Dissociation & [60] \\
\hline 21 & $\mathrm{e}^{-}+\mathrm{CH}_{4} \rightarrow \mathrm{CH}+\mathrm{H}_{2}+\mathrm{H}+\mathrm{e}^{-}$ & 12.50 & Dissociation & [60] \\
\hline 22 & $\mathrm{e}^{-}+\mathrm{CH}_{4} \rightarrow \mathrm{C}+\mathrm{H}_{2}+\mathrm{H}_{2}+\mathrm{e}^{-}$ & 14.00 & Dissociation & [60] \\
\hline 23 & $\mathrm{e}^{-}+\mathrm{CH}_{4} \rightarrow \mathrm{CH}_{4}^{+}+2 \mathrm{e}^{-}$ & 12.63 & Ionization & [61] \\
\hline 24 & $\begin{array}{l}\mathrm{e}^{-}+\mathrm{CH}_{4} \rightarrow \mathrm{CH}_{3}^{+}+\mathrm{H}+2 \mathrm{e}^{-} \\
\mathbf{C H}_{3}\end{array}$ & 14.01 & Dissociative ionization & {$[61]$} \\
\hline 25 & $\mathrm{e}^{-}+\mathrm{CH}_{3} \rightarrow \mathrm{CH}_{3}+\mathrm{e}^{-}$ & 0.000 & Momentum transfer & [62] \\
\hline 26 & $\mathrm{e}^{-}+\mathrm{CH}_{3} \rightarrow \mathrm{CH}_{2}+\mathrm{H}+\mathrm{e}^{-}$ & 9.500 & Dissociation & {$[62]$} \\
\hline 27 & $\mathrm{e}^{-}+\mathrm{CH}_{3} \rightarrow \mathrm{CH}+\mathrm{H}_{2}+\mathrm{e}^{-}$ & 10.000 & Dissociation & [62] \\
\hline 28 & $\begin{array}{l}\mathrm{e}^{-}+\mathrm{CH}_{3} \rightarrow \mathrm{CH}_{3}^{+}+2 \mathrm{e}^{-} \\
\mathbf{C}_{2} \mathbf{H}_{6}\end{array}$ & 9.800 & Ionization & {$[62]$} \\
\hline 29 & $\mathrm{e}^{-}+\mathrm{C}_{2} \mathrm{H}_{6} \rightarrow \mathrm{C}_{2} \mathrm{H}_{6}+\mathrm{e}^{-}$ & 0.000 & Momentum transfer & {$[63]$} \\
\hline 30 & $\mathrm{e}^{-}+\mathrm{C}_{2} \mathrm{H}_{6}{ }^{(0)} \rightarrow \mathrm{C}_{2} \mathrm{H}_{6}{ }^{(\mathrm{v}=1)}+\mathrm{e}^{-}$ & 0.3766 & Vibrational excitation & [63] \\
\hline 31 & $\mathrm{e}^{-}+\mathrm{C}_{2} \mathrm{H}_{6}{ }^{(0)} \rightarrow \mathrm{C}_{2} \mathrm{H}_{6}{ }^{(\mathrm{v}=2)}+\mathrm{e}^{-}$ & 0.1569 & Vibrational excitation & [63] \\
\hline 32 & $\mathrm{e}^{-}+\mathrm{C}_{2} \mathrm{H}_{6}{ }^{(0)} \rightarrow \mathrm{C}_{2} \mathrm{H}_{6}{ }^{(\mathrm{v}=3)}+\mathrm{e}^{-}$ & 0.1099 & Vibrational excitation & [63] \\
\hline 33 & $\mathrm{e}^{-}+\mathrm{C}_{2} \mathrm{H}_{6} \rightarrow \mathrm{C}_{2} \mathrm{H}_{5}+\mathrm{H}+\mathrm{e}^{-}$ & 7.45 & Dissociation & [63] \\
\hline 34 & $\mathrm{e}^{-}+\mathrm{C}_{2} \mathrm{H}_{6} \rightarrow \mathrm{C}_{2} \mathrm{H}_{4}+\mathrm{H}_{2}+\mathrm{e}^{-}$ & 4.00 & Dissociation & [63] \\
\hline 35 & $\mathrm{e}^{-}+\mathrm{C}_{2} \mathrm{H}_{6} \rightarrow \mathrm{C}_{2} \mathrm{H}_{6}^{+}+2 \mathrm{e}^{-}$ & 11.60 & Ionization & [63] \\
\hline 36 & $\mathrm{e}^{-}+\mathrm{C}_{2} \mathrm{H}_{6} \rightarrow \mathrm{C}_{2} \mathrm{H}_{5}^{+}+\mathrm{H}+2 \mathrm{e}^{-}$ & 12.65 & Dissociative ionization & [63] \\
\hline 37 & $\begin{array}{l}\mathrm{e}^{-}+\mathrm{C}_{2} \mathrm{H}_{6} \rightarrow \mathrm{C}_{2} \mathrm{H}_{4}^{+}+\mathrm{H}_{2}+2 \mathrm{e}^{-} \\
\mathbf{C}_{2} \mathrm{H}_{4}\end{array}$ & 11.81 & Dissociative ionization & {$[63]$} \\
\hline 38 & $\mathrm{e}^{-}+\mathrm{C}_{2} \mathrm{H}_{4} \rightarrow \mathrm{C}_{2} \mathrm{H}_{4}+\mathrm{e}^{-}$ & 0.000 & Momentum transfer & [63] \\
\hline 39 & $\mathrm{e}^{-}+\mathrm{C}_{2} \mathrm{H}_{4}{ }^{(0)} \rightarrow \mathrm{C}_{2} \mathrm{H}_{4}{ }^{(\mathrm{v}=1)}+\mathrm{e}^{-}$ & 0.3838 & Vibrational excitation & {$[63]$} \\
\hline 40 & $\mathrm{e}^{-}+\mathrm{C}_{2} \mathrm{H}_{4}{ }^{(0)} \rightarrow \mathrm{C}_{2} \mathrm{H}_{4}^{(\mathrm{v}=4)}+\mathrm{e}^{-}$ & 0.1197 & Vibrational excitation & [63] \\
\hline 41 & $\mathrm{e}^{-}+\mathrm{C}_{2} \mathrm{H}_{4} \rightarrow \mathrm{C}_{2} \mathrm{H}_{3}+\mathrm{H}+\mathrm{e}^{-}$ & 6.90 & Dissociation & [63] \\
\hline 42 & $\mathrm{e}^{-}+\mathrm{C}_{2} \mathrm{H}_{4} \rightarrow \mathrm{C}_{2} \mathrm{H}_{2}+\mathrm{H}_{2}+\mathrm{e}^{-}$ & 5.80 & Dissociation & [63] \\
\hline 43 & $\mathrm{e}^{-}+\mathrm{C}_{2} \mathrm{H}_{4} \rightarrow \mathrm{C}_{2} \mathrm{H}_{4}^{+}+2 \mathrm{e}^{-}$ & 11.00 & Ionization & [63] \\
\hline 44 & $\mathrm{e}^{-}+\mathrm{C}_{2} \mathrm{H}_{4} \rightarrow \mathrm{C}_{2} \mathrm{H}_{3}^{+}+\mathrm{H}+2 \mathrm{e}^{-}$ & 12.60 & Dissociative ionization & [63] \\
\hline
\end{tabular}




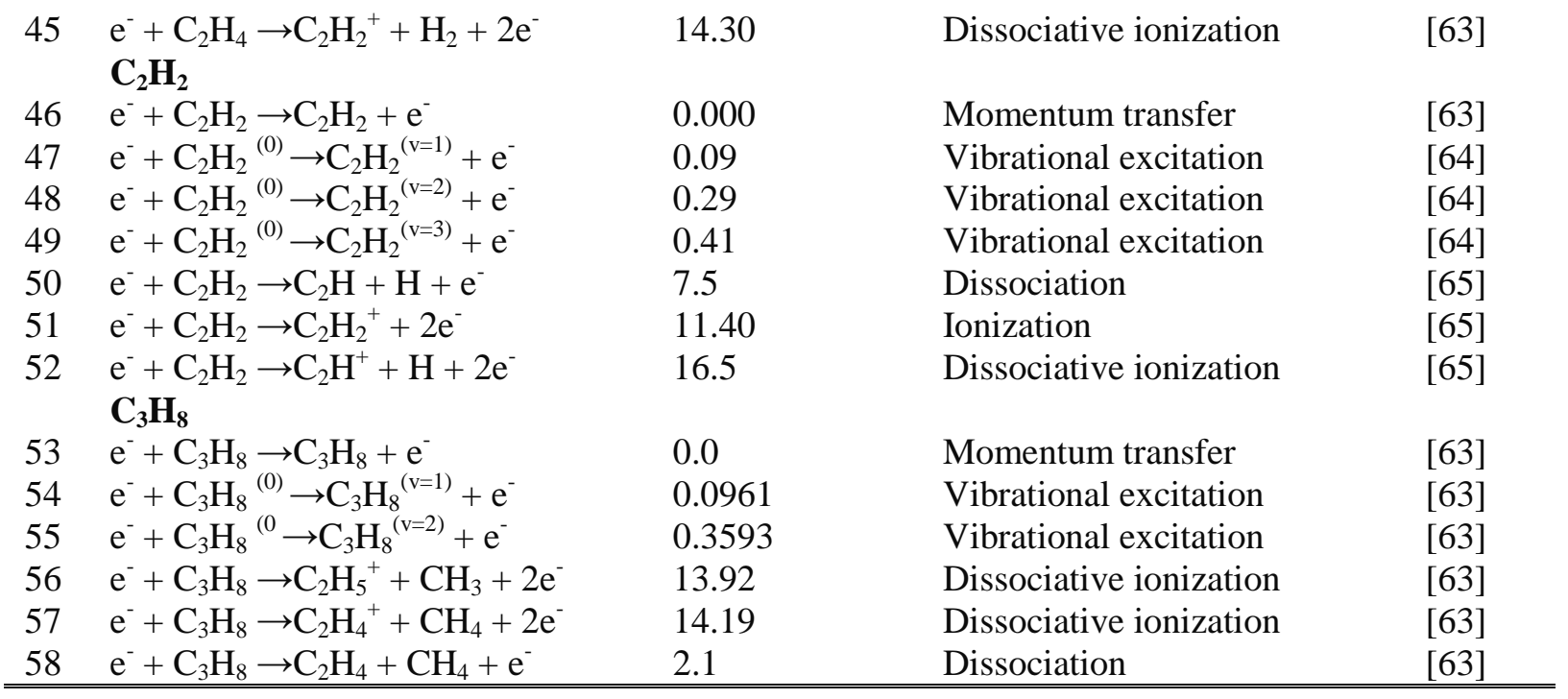


Table 5. Ion-molecule reactions taken into account in the $\mathrm{CH}_{4} / \mathrm{H}_{2}$ model, as well as their reaction rate coefficients. The latter were all adopted from [66].

\begin{tabular}{|c|c|c|}
\hline No. & Reaction & Coefficient $\left(\mathrm{cm}^{3} \mathrm{~s}^{-1}\right)$ \\
\hline 1 & $\mathrm{H}^{+}+\mathrm{H}_{2} \rightarrow \mathrm{H}_{2}^{+}+\mathrm{H}$ & $3.22 \times 10^{-10} \times \exp (21856 / \mathrm{T})$ \\
\hline 2 & $\mathrm{H}^{+}+\mathrm{CH} \rightarrow \mathrm{CH}^{+}+\mathrm{H}$ & $1.89 \times 10^{-9}$ \\
\hline 3 & $\mathrm{H}^{+}+\mathrm{CH}_{2} \rightarrow \mathrm{CH}^{+}+\mathrm{H}_{2}$ & $1.39 \times 10^{-9}$ \\
\hline 4 & $\mathrm{H}^{+}+\mathrm{CH}_{2} \rightarrow \mathrm{CH}_{2}^{+}+\mathrm{H}$ & $1.39 \times 10^{-9}$ \\
\hline 5 & $\mathrm{H}^{+}+\mathrm{CH}_{3} \rightarrow \mathrm{CH}_{3}^{+}+\mathrm{H}$ & $3.32 \times 10^{-9}$ \\
\hline 6 & $\mathrm{H}^{+}+\mathrm{CH}_{4} \rightarrow \mathrm{CH}_{3}^{+}+\mathrm{H}_{2}$ & $2.33 \times 10^{-9}$ \\
\hline 7 & $\mathrm{H}^{+}+\mathrm{C}_{2} \rightarrow \mathrm{C}_{2}^{+}+\mathrm{H}$ & $3.09 \times 10^{-9}$ \\
\hline 8 & $\mathrm{H}^{+}+\mathrm{C}_{2} \mathrm{H} \rightarrow \mathrm{C}_{2}^{+}+\mathrm{H}_{2}$ & $1.50 \times 10^{-9}$ \\
\hline 9 & $\mathrm{H}^{+}+\mathrm{C}_{2} \mathrm{H} \rightarrow \mathrm{C}_{2} \mathrm{H}^{+}+\mathrm{H}$ & $1.50 \times 10^{-9}$ \\
\hline 10 & $\mathrm{H}^{+}+\mathrm{C}_{2} \mathrm{H}_{2} \rightarrow \mathrm{C}_{2} \mathrm{H}^{+}+\mathrm{H}_{2}$ & $2.00 \times 10^{-9}$ \\
\hline 11 & $\mathrm{H}^{+}+\mathrm{C}_{2} \mathrm{H}_{2} \rightarrow \mathrm{C}_{2} \mathrm{H}_{2}^{+}+\mathrm{H}$ & $2.00 \times 10^{-9}$ \\
\hline 12 & $\mathrm{H}^{+}+\mathrm{C}_{2} \mathrm{H}_{3} \rightarrow \mathrm{C}_{2} \mathrm{H}_{2}^{+}+\mathrm{H}_{2}$ & $2.00 \times 10^{-9}$ \\
\hline 13 & $\mathrm{H}^{+}+\mathrm{C}_{2} \mathrm{H}_{3} \rightarrow \mathrm{C}_{2} \mathrm{H}_{3}^{+}+\mathrm{H}$ & $2.00 \times 10^{-9}$ \\
\hline 14 & $\mathrm{H}^{+}+\mathrm{C}_{2} \mathrm{H}_{4} \rightarrow \mathrm{C}_{2} \mathrm{H}_{2}^{+}+\mathrm{H}_{2}+\mathrm{H}$ & $1.00 \times 10^{-9}$ \\
\hline 15 & $\mathrm{H}^{+}+\mathrm{C}_{2} \mathrm{H}_{4} \rightarrow \mathrm{C}_{2} \mathrm{H}_{4}^{+}+\mathrm{H}$ & $1.00 \times 10^{-9}$ \\
\hline 16 & $\mathrm{H}^{+}+\mathrm{C}_{2} \mathrm{H}_{4} \rightarrow \mathrm{C}_{2} \mathrm{H}_{3}^{+}+\mathrm{H}_{2}$ & $3.00 \times 10^{-9}$ \\
\hline 17 & $\mathrm{H}^{+}+\mathrm{C}_{2} \mathrm{H}_{5} \rightarrow \mathrm{C}_{2} \mathrm{H}_{3}^{+}+\mathrm{H}_{2}+\mathrm{H}$ & $3.06 \times 10^{-9}$ \\
\hline 18 & $\mathrm{H}^{+}+\mathrm{C}_{2} \mathrm{H}_{5} \rightarrow \mathrm{C}_{2} \mathrm{H}_{4}^{+}+\mathrm{H}_{2}$ & $1.65 \times 10^{-9}$ \\
\hline 19 & $\mathrm{H}_{2}^{+}+\mathrm{H} \rightarrow \mathrm{H}^{+}+\mathrm{H}_{2}$ & $6.40 \times 10^{-10}$ \\
\hline 19 & $\mathrm{H}_{2}^{+}+\mathrm{H}_{2} \rightarrow \mathrm{H}_{3}^{+}+\mathrm{H}$ & $2.08 \times 10^{-9}$ \\
\hline 20 & $\mathrm{H}_{2}^{+}+\mathrm{C} \rightarrow \mathrm{CH}^{+}+\mathrm{H}$ & $2.40 \times 10^{-9}$ \\
\hline 21 & $\mathrm{H}_{2}^{+}+\mathrm{CH} \rightarrow \mathrm{CH}^{+}+\mathrm{H}_{2}$ & $7.10 \times 10^{-10}$ \\
\hline 22 & $\mathrm{H}_{2}^{+}+\mathrm{CH} \rightarrow \mathrm{CH}_{2}^{+}+\mathrm{H}$ & $7.10 \times 10^{-10}$ \\
\hline 23 & $\mathrm{H}_{2}^{+}+\mathrm{CH}_{2} \rightarrow \mathrm{CH}_{3}^{+}+\mathrm{H}$ & $1.00 \times 10^{-9}$ \\
\hline 24 & $\mathrm{H}_{2}^{+}+\mathrm{CH}_{2} \rightarrow \mathrm{CH}_{2}^{+}+\mathrm{H}_{2}$ & $1.00 \times 10^{-9}$ \\
\hline 25 & $\mathrm{H}_{2}^{+}+\mathrm{CH}_{4} \rightarrow \mathrm{CH}_{5}^{+}+\mathrm{H}$ & $1.14 \times 10^{-10}$ \\
\hline 26 & $\mathrm{H}_{2}^{+}+\mathrm{CH}_{4} \rightarrow \mathrm{CH}_{4}^{+}+\mathrm{H}_{2}$ & $1.40 \times 10^{-9}$ \\
\hline 27 & $\mathrm{H}_{2}^{+}+\mathrm{CH}_{4} \rightarrow \mathrm{CH}_{3}^{+}+\mathrm{H}_{2}+\mathrm{H}$ & $2.30 \times 10^{-9}$ \\
\hline 28 & $\mathrm{H}_{2}^{+}+\mathrm{C}_{2} \rightarrow \mathrm{C}_{2}^{+}+\mathrm{H}_{2}$ & $1.10 \times 10^{-9}$ \\
\hline 29 & $\mathrm{H}_{2}^{+}+\mathrm{C}_{2} \rightarrow \mathrm{C}_{2} \mathrm{H}^{+}+\mathrm{H}$ & $1.10 \times 10^{-9}$ \\
\hline 30 & $\mathrm{H}_{2}^{+}+\mathrm{C}_{2} \mathrm{H} \rightarrow \mathrm{C}_{2} \mathrm{H}^{+}+\mathrm{H}_{2}$ & $1.00 \times 10^{-9}$ \\
\hline 31 & $\mathrm{H}_{2}^{+}+\mathrm{C}_{2} \mathrm{H} \rightarrow \mathrm{C}_{2} \mathrm{H}_{2}^{+}+\mathrm{H}$ & $1.00 \times 10^{-9}$ \\
\hline 32 & $\mathrm{H}_{2}^{+}+\mathrm{C}_{2} \mathrm{H}_{2} \rightarrow \mathrm{C}_{2} \mathrm{H}_{3}^{+}+\mathrm{H}$ & $4.80 \times 10^{-10}$ \\
\hline 33 & $\mathrm{H}_{2}^{+}+\mathrm{C}_{2} \mathrm{H}_{2} \rightarrow \mathrm{C}_{2} \mathrm{H}_{2}^{+}+\mathrm{H}_{2}$ & $4.82 \times 10^{-9}$ \\
\hline 34 & $\mathrm{H}_{2}^{+}+\mathrm{C}_{2} \mathrm{H}_{4} \rightarrow \mathrm{C}_{2} \mathrm{H}_{3}^{+}+\mathrm{H}_{2}+\mathrm{H}$ & $1.81 \times 10^{-9}$ \\
\hline 35 & $\mathrm{H}_{2}^{+}+\mathrm{C}_{2} \mathrm{H}_{4} \rightarrow \mathrm{C}_{2} \mathrm{H}_{4}^{+}+\mathrm{H}_{2}$ & $2.21 \times 10^{-9}$ \\
\hline 36 & $\mathrm{H}_{2}^{+}+\mathrm{C}_{2} \mathrm{H}_{4} \rightarrow \mathrm{C}_{2} \mathrm{H}_{2}^{+}+\mathrm{H}_{2}+\mathrm{H}_{2}$ & $8.82 \times 10^{-9}$ \\
\hline 37 & $\mathrm{H}_{3}^{+}+\mathrm{C} \rightarrow \mathrm{CH}^{+}+\mathrm{H}_{2}$ & $2.00 \times 10^{-9}$ \\
\hline 38 & $\mathrm{H}_{3}^{+}+\mathrm{CH} \rightarrow \mathrm{CH}_{2}^{+}+\mathrm{H}_{2}$ & $1.20 \times 10^{-9}$ \\
\hline 39 & $\mathrm{H}_{3}^{+}+\mathrm{CH}_{2} \rightarrow \mathrm{CH}_{3}^{+}+\mathrm{H}_{2}$ & $1.70 \times 10^{-9}$ \\
\hline 40 & $\mathrm{H}_{3}^{+}+\mathrm{CH}_{3} \rightarrow \mathrm{CH}_{4}^{+}+\mathrm{H}_{2}$ & $2.10 \times 10^{-9}$ \\
\hline 41 & $\mathrm{H}_{3}^{+}+\mathrm{CH}_{4} \rightarrow \mathrm{CH}_{5}^{+}+\mathrm{H}_{2}$ & $2.40 \times 10^{-9}$ \\
\hline 42 & $\mathrm{H}_{3}^{+}+\mathrm{C}_{2} \rightarrow \mathrm{C}_{2} \mathrm{H}^{+}+\mathrm{H}_{2}$ & $1.80 \times 10^{-9}$ \\
\hline 43 & $\mathrm{H}_{3}^{+}+\mathrm{C}_{2} \mathrm{H} \rightarrow \mathrm{C}_{2} \mathrm{H}_{2}^{+}+\mathrm{H}_{2}$ & $1.70 \times 10^{-9}$ \\
\hline 44 & $\mathrm{H}_{3}{ }^{+}+\mathrm{C}_{2} \mathrm{H}_{2} \rightarrow \mathrm{C}_{2} \mathrm{H}_{3}{ }^{+}+\mathrm{H}_{2}$ & $3.50 \times 10^{-9}$ \\
\hline 45 & $\mathrm{H}_{3}^{+}+\mathrm{C}_{2} \mathrm{H}_{3} \rightarrow \mathrm{C}_{2} \mathrm{H}_{4}^{+}+\mathrm{H}_{2}$ & $2.00 \times 10^{-9}$ \\
\hline 46 & $\mathrm{H}_{3}^{+}+\mathrm{C}_{2} \mathrm{H}_{4} \rightarrow \mathrm{C}_{2} \mathrm{H}_{5}^{+}+\mathrm{H}_{2}$ & $1.15 \times 10^{-9}$ \\
\hline 47 & $\mathrm{H}_{3}^{+}+\mathrm{C}_{2} \mathrm{H}_{4} \rightarrow \mathrm{C}_{2} \mathrm{H}_{3}^{+}+\mathrm{H}_{2}+\mathrm{H}_{2}$ & $1.15 \times 10^{-9}$ \\
\hline 48 & $\mathrm{H}_{3}^{+}+\mathrm{C}_{2} \mathrm{H}_{5} \rightarrow \mathrm{C}_{2} \mathrm{H}_{6}^{+}+\mathrm{H}_{2}$ & $1.40 \times 10^{-9}$ \\
\hline 49 & $\mathrm{C}^{+}+\mathrm{CH} \rightarrow \mathrm{C}_{2}^{+}+\mathrm{H}$ & $3.82 \times 10^{-10}$ \\
\hline
\end{tabular}




$$
\mathrm{C}^{+}+\mathrm{CH} \rightarrow \mathrm{CH}^{+}+\mathrm{C}
$$$$
\mathrm{C}^{+}+\mathrm{CH}_{2} \rightarrow \mathrm{C}_{2} \mathrm{H}^{+}+\mathrm{H}
$$$$
\mathrm{C}^{+}+\mathrm{CH}_{2} \rightarrow \mathrm{CH}_{2}^{+}+\mathrm{C}
$$$$
\mathrm{C}^{+}+\mathrm{CH}_{4} \rightarrow \mathrm{C}_{2} \mathrm{H}_{2}^{+}+\mathrm{H}_{2}
$$$$
\mathrm{C}^{+}+\mathrm{CH}_{4} \rightarrow \mathrm{C}_{2} \mathrm{H}_{3}^{+}+\mathrm{H}
$$$$
\mathrm{C}^{+}+\mathrm{C}_{2} \mathrm{H}_{4} \rightarrow \mathrm{C}_{2} \mathrm{H}_{3}^{+}+\mathrm{CH}
$$$$
\mathrm{C}^{+}+\mathrm{C}_{2} \mathrm{H}_{4} \rightarrow \mathrm{C}_{2} \mathrm{H}_{4}^{+}+\mathrm{C}
$$$$
\mathrm{C}^{+}+\mathrm{C}_{2} \mathrm{H}_{5} \rightarrow \mathrm{C}_{2} \mathrm{H}_{5}^{+}+\mathrm{C}
$$$$
\mathrm{CH}^{+}+\mathrm{H} \rightarrow \mathrm{C}^{+}+\mathrm{H}_{2}
$$$$
\mathrm{CH}^{+}+\mathrm{H}_{2} \rightarrow \mathrm{CH}_{2}^{+}+\mathrm{H}
$$$$
\mathrm{CH}^{+}+\mathrm{C} \rightarrow \mathrm{C}_{2}^{+}+\mathrm{H}
$$$$
\mathrm{CH}^{+}+\mathrm{CH} \rightarrow \mathrm{C}_{2}^{+}+\mathrm{H}_{2}
$$$$
\mathrm{CH}^{+}+\mathrm{CH}_{2} \rightarrow \mathrm{C}_{2} \mathrm{H}^{+}+\mathrm{H}_{2}
$$$$
\mathrm{CH}^{+}+\mathrm{CH}_{4} \rightarrow \mathrm{C}_{2} \mathrm{H}_{2}^{+}+\mathrm{H}_{2}+\mathrm{H}
$$$$
\mathrm{CH}^{+}+\mathrm{CH}_{4} \rightarrow \mathrm{C}_{2} \mathrm{H}_{4}^{+}+\mathrm{H}
$$$$
\mathrm{CH}^{+}+\mathrm{CH}_{4} \rightarrow \mathrm{C}_{2} \mathrm{H}_{3}^{+}+\mathrm{H}_{2}
$$$$
\mathrm{CH}_{2}{ }^{+}+\mathrm{H} \rightarrow \mathrm{CH}^{+}+\mathrm{H}_{2}
$$$$
\mathrm{CH}_{2}^{+}+\mathrm{H}_{2} \rightarrow \mathrm{CH}_{3}{ }^{+}+\mathrm{H}
$$$$
\mathrm{CH}_{2}{ }^{+}+\mathrm{C} \rightarrow \mathrm{C}_{2} \mathrm{H}^{+}+\mathrm{H}
$$$$
\mathrm{CH}_{2}^{+}+\mathrm{CH}_{4} \rightarrow \mathrm{C}_{2} \mathrm{H}_{4}^{+}+\mathrm{H}_{2}
$$$$
\mathrm{CH}_{2}^{+}+\mathrm{CH}_{4} \rightarrow \mathrm{C}_{2} \mathrm{H}_{5}^{+}+\mathrm{H}
$$$$
\mathrm{CH}_{3}{ }^{+}+\mathrm{H} \rightarrow \mathrm{CH}_{2}{ }^{+}+\mathrm{H}_{2}
$$$$
\mathrm{CH}_{3}{ }^{+}+\mathrm{C} \rightarrow \mathrm{C}_{2} \mathrm{H}^{+}+\mathrm{H}_{2}
$$$$
\mathrm{CH}_{2}^{+}+\mathrm{CH} \rightarrow \mathrm{C}_{2} \mathrm{H}_{2}^{+}+\mathrm{H}_{2}
$$$$
\mathrm{CH}_{2}^{+}+\mathrm{CH}_{2} \rightarrow \mathrm{C}_{2} \mathrm{H}_{3}^{+}+\mathrm{H}_{2}
$$$$
\mathrm{CH}_{3}{ }^{+}+\mathrm{CH}_{4} \rightarrow \mathrm{C}_{2} \mathrm{H}_{5}{ }^{+}+\mathrm{H}_{2}
$$$$
\mathrm{CH}_{3}{ }^{+}+\mathrm{C}_{2} \mathrm{H}_{3} \rightarrow \mathrm{C}_{2} \mathrm{H}_{3}{ }^{+}+\mathrm{CH}_{3}
$$$$
\mathrm{CH}_{3}{ }^{+}+\mathrm{C}_{2} \mathrm{H}_{4} \rightarrow \mathrm{C}_{2} \mathrm{H}_{3}{ }^{+}+\mathrm{CH}_{4}
$$$$
\mathrm{CH}_{4}{ }^{+}+\mathrm{H} \rightarrow \mathrm{CH}_{3}{ }^{+}+\mathrm{H}_{2}
$$$$
\mathrm{CH}_{4}^{+}+\mathrm{H}_{2} \rightarrow \mathrm{CH}_{5}^{+}+\mathrm{H}
$$$$
\mathrm{CH}_{4}{ }^{+}+\mathrm{CH}_{4} \rightarrow \mathrm{CH}_{5}^{+}+\mathrm{CH}_{3}
$$$$
\mathrm{CH}_{4}{ }^{+}+\mathrm{C}_{2} \mathrm{H}_{2} \rightarrow \mathrm{C}_{2} \mathrm{H}_{2}{ }^{+}+\mathrm{CH}_{4}
$$$$
\mathrm{CH}_{4}{ }^{+}+\mathrm{C}_{2} \mathrm{H}_{2} \rightarrow \mathrm{C}_{2} \mathrm{H}_{3}{ }^{+}+\mathrm{CH}_{3}
$$$$
\mathrm{CH}_{4}{ }^{+}+\mathrm{C}_{2} \mathrm{H}_{4} \rightarrow \mathrm{C}_{2} \mathrm{H}_{4}^{+}+\mathrm{CH}_{4}
$$$$
\mathrm{CH}_{4}^{+}+\mathrm{C}_{2} \mathrm{H}_{4} \rightarrow \mathrm{C}_{2} \mathrm{H}_{5}^{+}+\mathrm{CH}_{3}
$$$$
\mathrm{CH}_{5}{ }^{+}+\mathrm{H} \rightarrow \mathrm{CH}_{4}{ }^{+}+\mathrm{H}_{2}
$$$$
\mathrm{CH}_{5}^{+}+\mathrm{C} \rightarrow \mathrm{CH}^{+}+\mathrm{CH}_{4}
$$$$
\mathrm{CH}_{5}{ }^{+}+\mathrm{CH} \rightarrow \mathrm{CH}_{2}^{+}+\mathrm{CH}_{4}
$$$$
\mathrm{CH}_{5}{ }^{+}+\mathrm{CH}_{2} \rightarrow \mathrm{CH}_{3}{ }^{+}+\mathrm{CH}_{4}
$$$$
\mathrm{CH}_{5}^{+}+\mathrm{C}_{2} \rightarrow \mathrm{C}_{2} \mathrm{H}^{+}+\mathrm{CH}_{4}
$$$$
\mathrm{CH}_{5}{ }^{+}+\mathrm{C}_{2} \mathrm{H} \rightarrow \mathrm{C}_{2} \mathrm{H}_{2}^{+}+\mathrm{CH}_{4}
$$$$
\mathrm{CH}_{5}{ }^{+}+\mathrm{C}_{2} \mathrm{H}_{2} \rightarrow \mathrm{C}_{2} \mathrm{H}_{3}{ }^{+}+\mathrm{CH}_{4}
$$$$
\mathrm{CH}_{5}{ }^{+}+\mathrm{C}_{2} \mathrm{H}_{4} \rightarrow \mathrm{C}_{2} \mathrm{H}_{5}^{+}+\mathrm{CH}_{4}
$$$$
\mathrm{C}_{2}^{+}+\mathrm{H}_{2} \rightarrow \mathrm{C}_{2} \mathrm{H}^{+}+\mathrm{H}
$$$$
\mathrm{C}_{2}^{+}+\mathrm{C} \rightarrow \mathrm{C}^{+}+\mathrm{C}_{2}
$$$$
\mathrm{C}_{2}^{+}+\mathrm{CH} \rightarrow \mathrm{CH}^{+}+\mathrm{C}_{2}
$$$$
\mathrm{C}_{2}^{+}+\mathrm{CH}_{2} \rightarrow \mathrm{CH}_{2}^{+}+\mathrm{C}_{2}
$$$$
\mathrm{C}_{2}^{+}+\mathrm{CH}_{4} \rightarrow \mathrm{C}_{2} \mathrm{H}^{+}+\mathrm{CH}_{3}
$$$$
\mathrm{C}_{2}^{+}+\mathrm{CH}_{4} \rightarrow \mathrm{C}_{2} \mathrm{H}_{2}^{+}+\mathrm{CH}_{2}
$$$$
\mathrm{C}_{2} \mathrm{H}^{+}+\mathrm{H}_{2} \rightarrow \mathrm{C}_{2} \mathrm{H}_{2}^{+}+\mathrm{H}
$$$$
\mathrm{C}_{2} \mathrm{H}^{+}+\mathrm{CH} \rightarrow \mathrm{CH}_{2}^{+}+\mathrm{C}_{2}
$$$$
\mathrm{C}_{2} \mathrm{H}^{+}+\mathrm{CH}_{2} \rightarrow \mathrm{CH}_{3}{ }^{+}+\mathrm{C}_{2}
$$$$
\mathrm{C}_{2} \mathrm{H}^{+}+\mathrm{CH}_{4} \rightarrow \mathrm{C}_{2} \mathrm{H}_{2}^{+}+\mathrm{CH}_{3}
$$$$
\mathrm{C}_{2} \mathrm{H}_{2}{ }^{+}+\mathrm{H}_{2} \rightarrow \mathrm{C}_{2} \mathrm{H}_{3}^{+}+\mathrm{H}
$$$$
\mathrm{C}_{2} \mathrm{H}_{2}^{+}+\mathrm{C}_{2} \mathrm{H}_{3} \rightarrow \mathrm{C}_{2} \mathrm{H}_{3}{ }^{+}+\mathrm{C}_{2} \mathrm{H}_{2}
$$

$3.82 \times 10^{-10}$

$5.15 \times 10^{-10}$

$5.15 \times 10^{-10}$

$3.16 \times 10^{-10}$

$9.63 \times 10^{-10}$

$8.50 \times 10^{-11}$

$1.70 \times 10^{-11}$

$5.00 \times 10^{-10}$

$7.50 \times 10^{-10}$

$1.20 \times 10^{-9}$

$1.20 \times 10^{-9}$

$1.00 \times 10^{-9}$

$7.50 \times 10^{-10}$

$1.43 \times 10^{-10}$

$6.50 \times 10^{-11}$

$1.09 \times 10^{-9}$

$1.00 \times 10^{-9}$

$1.60 \times 10^{-9}$

$1.20 \times 10^{-9}$

$8.40 \times 10^{-10}$

$3.60 \times 10^{-10}$

$7.00 \times 10^{-10}$

$1.20 \times 10^{-9}$

$7.10 \times 10^{-10}$

$9.90 \times 10^{-10}$

$1.20 \times 10^{-9}$

$3.00 \times 10^{-10}$

$3.50 \times 10^{-10}$

$1.10 \times 10^{-11}$

$3.30 \times 10^{-11}$

$1.50 \times 10^{-9}$

$1.13 \times 10^{-9}$

$1.23 \times 10^{-9}$

$1.38 \times 10^{-9}$

$4.23 \times 10^{-10}$

$1.50 \times 10^{-10}$

$1.20 \times 10^{-9}$

$6.90 \times 10^{-10}$

$9.60 \times 10^{-10}$

$9.50 \times 10^{-10}$

$9.00 \times 10^{-10}$

$1.60 \times 10^{-9}$

$1.50 \times 10^{-9}$

$1.10 \times 10^{-9}$

$1.10 \times 10^{-10}$

$3.20 \times 10^{-10}$

$4.50 \times 10^{-10}$

$2.38 \times 10^{-10}$

$1.82 \times 10^{-10}$

$1.10 \times 10^{-9}$

$3.20 \times 10^{-10}$

$4.40 \times 10^{-10}$

$3.74 \times 10^{-10}$

$1.00 \times 10^{-11}$

$3.30 \times 10^{-10}$ 


\begin{tabular}{lll}
105 & $\mathrm{C}_{2} \mathrm{H}_{2}^{+}+\mathrm{C}_{2} \mathrm{H}_{4} \rightarrow \mathrm{C}_{2} \mathrm{H}_{4}^{+}+\mathrm{C}_{2} \mathrm{H}_{2}$ & $4.14 \times 10^{-10}$ \\
106 & $\mathrm{C}_{2} \mathrm{H}_{3}^{+}+\mathrm{H} \rightarrow \mathrm{C}_{2} \mathrm{H}_{2}^{+}+\mathrm{H}_{2}$ & $6.80 \times 10^{-11}$ \\
107 & $\mathrm{C}_{2} \mathrm{H}_{3}^{+}+\mathrm{C}_{2} \mathrm{H} \rightarrow \mathrm{C}_{2} \mathrm{H}_{2}^{+}+\mathrm{C}_{2} \mathrm{H}_{2}$ & $3.30 \times 10^{-10}$ \\
108 & $\mathrm{C}_{2} \mathrm{H}_{3}^{+}+\mathrm{C}_{2} \mathrm{H}_{3} \rightarrow \mathrm{C}_{2} \mathrm{H}_{5}^{+}+\mathrm{C}_{2} \mathrm{H}$ & $5.00 \times 10^{-10}$ \\
109 & $\mathrm{C}_{2} \mathrm{H}_{3}^{+}+\mathrm{C}_{2} \mathrm{H}_{4} \rightarrow \mathrm{C}_{2} \mathrm{H}_{5}^{+}+\mathrm{C}_{2} \mathrm{H}_{2}$ & $8.90 \times 10^{-10}$ \\
110 & $\mathrm{C}_{2} \mathrm{H}_{4}^{+}+\mathrm{H} \rightarrow \mathrm{C}_{2} \mathrm{H}_{3}^{+}+\mathrm{H}_{2}$ & $3.00 \times 10^{-10}$ \\
111 & $\mathrm{C}_{2} \mathrm{H}_{4}^{+}+\mathrm{C}_{2} \mathrm{H}_{3} \rightarrow \mathrm{C}_{2} \mathrm{H}_{3}^{+}+\mathrm{C}_{2} \mathrm{H}_{4}$ & $5.00 \times 10^{-10}$ \\
112 & $\mathrm{C}_{2} \mathrm{H}_{4}^{+}+\mathrm{C}_{2} \mathrm{H}_{3} \rightarrow \mathrm{C}_{2} \mathrm{H}_{5}^{+}+\mathrm{C}_{2} \mathrm{H}_{2}$ & $5.00 \times 10^{-10}$ \\
113 & $\mathrm{C}_{2} \mathrm{H}_{5}^{+}+\mathrm{H} \rightarrow \mathrm{C}_{2} \mathrm{H}_{4}^{+}+\mathrm{H}_{2}$ & $1.00 \times 10^{-11}$ \\
114 & $\mathrm{C}_{2} \mathrm{H}_{6}^{+}+\mathrm{H} \rightarrow \mathrm{C}_{2} \mathrm{H}_{5}^{+}+\mathrm{H}_{2}$ & $1.00 \times 10^{-10}$ \\
115 & $\mathrm{C}_{2} \mathrm{H}_{6}{ }^{+}+\mathrm{C}_{2} \mathrm{H}_{2} \rightarrow \mathrm{C}_{2} \mathrm{H}_{5}^{+}+\mathrm{C}_{2} \mathrm{H}_{3}$ & $2.47 \times 10^{-10}$ \\
\hline
\end{tabular}


Table 6. Neutral-neutral reactions taken into account in the $\mathrm{CH}_{4} / \mathrm{H}_{2}$ model. The rate coefficients are calculated by $\mathrm{k}=\mathrm{k}_{0} \times\left(\mathrm{T}_{\mathrm{g}} / 298\right)^{\mathrm{n}} \times \exp \left(-\mathrm{E}_{\mathrm{a}} / \mathrm{T}_{\mathrm{g}}\right)$, where $\mathrm{T}_{\mathrm{g}}$ is the gas temperature $(\mathrm{K})$. The parameters $\mathrm{k}_{0}, \mathrm{n}$, and $\mathrm{E}_{\mathrm{a}}$ are given in the table; they were all adopted from $[30,67,68]$.

\begin{tabular}{|c|c|c|c|c|}
\hline \multirow{2}{*}{ No. } & \multirow{2}{*}{ Reactions } & \multicolumn{3}{|c|}{ Rate coefficient } \\
\hline & & $\mathrm{k}_{0}\left(\mathrm{~cm}^{3} \mathrm{~s}^{-1}\right)$ & $\mathrm{n}$ & $E_{a} / R$ \\
\hline 1 & $\mathrm{H}+\mathrm{H}+\mathrm{M} \rightarrow \mathrm{H}_{2}+\mathrm{M}$ & $1.90 \times 10^{-31}$ & -0.06 & 0 \\
\hline 2 & $\mathrm{CH}_{4}+\mathrm{CH}_{3} \rightarrow \mathrm{C}_{2} \mathrm{H}_{5}+\mathrm{H}_{2}$ & $1.70 \times 10^{-11}$ & 0 & 11500 \\
\hline 3 & $\mathrm{CH}_{4}+\mathrm{CH}_{2} \rightarrow \mathrm{CH}_{3}+\mathrm{CH}_{3}$ & $7.10 \times 10^{-12}$ & 0 & 5020 \\
\hline 4 & $\mathrm{CH}_{4}+\mathrm{CH}_{2} \rightarrow \mathrm{C}_{2} \mathrm{H}_{4}+\mathrm{H}_{2}$ & $1.70 \times 10^{-11}$ & 0 & 0 \\
\hline 5 & $\mathrm{CH}_{4}+\mathrm{CH} \rightarrow \mathrm{C}_{2} \mathrm{H}_{5}$ & $1.00 \times 10^{-10}$ & 0 & 0 \\
\hline 6 & $\mathrm{CH}_{4}+\mathrm{CH} \rightarrow \mathrm{C}_{2} \mathrm{H}_{4}+\mathrm{H}$ & $5.00 \times 10^{-11}$ & 0 & -200 \\
\hline 7 & $\mathrm{CH}_{4}+\mathrm{C}_{2} \mathrm{H}_{3} \rightarrow \mathrm{C}_{2} \mathrm{H}_{4}+\mathrm{CH}_{2}$ & $1.89 \times 10^{-14}$ & 4.0 & 2754 \\
\hline 8 & $\mathrm{CH}_{4}+\mathrm{C}_{2} \mathrm{H} \rightarrow \mathrm{C}_{2} \mathrm{H}_{2}+\mathrm{CH}_{3}$ & $3.00 \times 10^{-12}$ & 0 & 250 \\
\hline 9 & $\mathrm{CH}_{4}+\mathrm{H} \rightarrow \mathrm{CH}_{3}+\mathrm{H}_{2}$ & $5.82 \times 10^{-13}$ & 3.0 & 4045 \\
\hline 10 & $\mathrm{CH}_{3}+\mathrm{CH}_{3} \rightarrow \mathrm{C}_{2} \mathrm{H}_{6}$ & $4.10 \times 10^{-11}$ & -0.4 & 0 \\
\hline 11 & $\mathrm{CH}_{3}+\mathrm{CH}_{3} \rightarrow \mathrm{C}_{2} \mathrm{H}_{5}+\mathrm{H}$ & $5.00 \times 10^{-11}$ & 0 & 6800 \\
\hline 12 & $\mathrm{CH}_{3}+\mathrm{CH}_{3} \rightarrow \mathrm{C}_{2} \mathrm{H}_{4}+\mathrm{H}_{2}$ & $1.70 \times 10^{-08}$ & 0 & 16000 \\
\hline 13 & $\mathrm{CH}_{3}+\mathrm{CH}_{2} \rightarrow \mathrm{C}_{2} \mathrm{H}_{4}+\mathrm{H}$ & $7.00 \times 10^{-11}$ & 0 & 0 \\
\hline 14 & $\mathrm{CH}_{3}+\mathrm{CH} \rightarrow \mathrm{C}_{2} \mathrm{H}_{3}+\mathrm{H}$ & $5.00 \times 10^{-11}$ & 0 & 0 \\
\hline 15 & $\mathrm{CH}_{3}+\mathrm{C} \rightarrow \mathrm{C}_{2} \mathrm{H}_{2}+\mathrm{H}$ & $8.30 \times 10^{-11}$ & 0 & 0 \\
\hline 16 & $\mathrm{CH}_{3}+\mathrm{H} \rightarrow \mathrm{CH}_{4}$ & $7.00 \times 10^{-12}$ & 0 & 0 \\
\hline 17 & $\mathrm{CH}_{3}+\mathrm{H} \rightarrow \mathrm{CH}_{2}+\mathrm{H}_{2}$ & $1.00 \times 10^{-10}$ & 0 & 7600 \\
\hline 18 & $\mathrm{CH}_{3}+\mathrm{C}_{2} \mathrm{H}_{5} \rightarrow \mathrm{C}_{2} \mathrm{H}_{4}+\mathrm{CH}_{4}$ & $1.90 \times 10^{-12}$ & 0 & 0 \\
\hline 19 & $\mathrm{CH}_{3}+\mathrm{C}_{2} \mathrm{H}_{5} \rightarrow \mathrm{C}_{3} \mathrm{H}_{8}$ & $4.70 \times 10^{-11}$ & 0 & 0 \\
\hline 20 & $\mathrm{CH}_{3}+\mathrm{C}_{2} \mathrm{H}_{3} \rightarrow \mathrm{C}_{2} \mathrm{H}_{2}+\mathrm{CH}_{4}$ & $6.50 \times 10^{-14}$ & 0 & 0 \\
\hline 21 & $\mathrm{CH}_{2}+\mathrm{CH}_{2} \rightarrow \mathrm{C}_{2} \mathrm{H}_{4}$ & $1.70 \times 10^{-12}$ & 0 & 0 \\
\hline 22 & $\mathrm{CH}_{2}+\mathrm{CH}_{2} \rightarrow \mathrm{C}_{2} \mathrm{H}_{2}+\mathrm{H}+\mathrm{H}$ & $1.80 \times 10^{-10}$ & 0 & 400 \\
\hline 23 & $\mathrm{CH}_{2}+\mathrm{CH}_{2} \rightarrow \mathrm{C}_{2} \mathrm{H}_{2}+\mathrm{H}_{2}$ & $2.00 \times 10^{-11}$ & 0 & 400 \\
\hline 24 & $\mathrm{CH}_{2}+\mathrm{CH} \rightarrow \mathrm{C}_{2} \mathrm{H}_{2}+\mathrm{H}$ & $6.60 \times 10^{-11}$ & 0 & 0 \\
\hline 25 & $\mathrm{CH}_{2}+\mathrm{C} \rightarrow \mathrm{C}_{2} \mathrm{H}+\mathrm{H}$ & $8.30 \times 10^{-11}$ & 0 & 0 \\
\hline 26 & $\mathrm{CH}_{2}+\mathrm{H} \rightarrow \mathrm{CH}+\mathrm{H}_{2}$ & $7.70 \times 10^{-10}$ & 0 & 0 \\
\hline 27 & $\mathrm{CH}_{2}+\mathrm{C}_{2} \mathrm{H}_{3} \rightarrow \mathrm{C}_{2} \mathrm{H}_{2}+\mathrm{CH}_{3}$ & $3.00 \times 10^{-11}$ & 0 & 0 \\
\hline 28 & $\mathrm{CH}_{2}+\mathrm{C}_{2} \mathrm{H} \rightarrow \mathrm{C}_{2} \mathrm{H}_{2}+\mathrm{CH}$ & $3.00 \times 10^{-11}$ & 0 & 0 \\
\hline 29 & $\mathrm{CH}+\mathrm{CH} \rightarrow \mathrm{C}_{2} \mathrm{H}_{2}$ & $2.00 \times 10^{-10}$ & 0 & 0 \\
\hline 30 & $\mathrm{C}_{2} \mathrm{H}_{5}+\mathrm{C}_{2} \mathrm{H}_{5} \rightarrow \mathrm{C}_{2} \mathrm{H}_{6}+\mathrm{C}_{2} \mathrm{H}_{4}$ & $2.40 \times 10^{-12}$ & 0 & 0 \\
\hline 31 & $\mathrm{C}_{2} \mathrm{H}_{5}+\mathrm{C}_{2} \mathrm{H}_{5} \rightarrow \mathrm{C}_{4} \mathrm{H}_{10}$ & $1.90 \times 10^{-11}$ & 0 & 0 \\
\hline 32 & $\mathrm{C}_{2} \mathrm{H}_{5}+\mathrm{C}_{2} \mathrm{H}_{3} \rightarrow \mathrm{C}_{2} \mathrm{H}_{6}+\mathrm{C}_{2} \mathrm{H}_{2}$ & $8.00 \times 10^{-13}$ & 0 & 0 \\
\hline 33 & $\mathrm{C}_{2} \mathrm{H}_{5}+\mathrm{C}_{2} \mathrm{H}_{3} \rightarrow \mathrm{C}_{2} \mathrm{H}_{4}+\mathrm{C}_{2} \mathrm{H}_{4}$ & $8.00 \times 10^{-13}$ & 0 & 0 \\
\hline 34 & $\mathrm{C}_{2} \mathrm{H}_{5}+\mathrm{C}_{2} \mathrm{H} \rightarrow \mathrm{C}_{2} \mathrm{H}_{4}+\mathrm{C}_{2} \mathrm{H}_{2}$ & $3.00 \times 10^{-12}$ & 0 & 0 \\
\hline 35 & $\mathrm{C}_{2} \mathrm{H}_{5}+\mathrm{H} \rightarrow \mathrm{C}_{2} \mathrm{H}_{6}$ & $6.00 \times 10^{-11}$ & 0 & 0 \\
\hline 36 & $\mathrm{C}_{2} \mathrm{H}_{5}+\mathrm{H} \rightarrow \mathrm{CH}_{3}+\mathrm{CH}_{3}$ & $6.00 \times 10^{-11}$ & 0 & 0 \\
\hline 37 & $\mathrm{C}_{2} \mathrm{H}_{5}+\mathrm{H} \rightarrow \mathrm{C}_{2} \mathrm{H}_{4}+\mathrm{H}_{2}$ & $3.00 \times 10^{-12}$ & 0 & 0 \\
\hline 38 & $\mathrm{C}_{2} \mathrm{H}_{3}+\mathrm{H} \rightarrow \mathrm{C}_{2} \mathrm{H}_{2}+\mathrm{H}_{2}$ & $2.00 \times 10^{-11}$ & 0 & 0 \\
\hline 39 & $\mathrm{C}_{2} \mathrm{H}_{6}+\mathrm{CH}_{3} \rightarrow \mathrm{C}_{2} \mathrm{H}_{5}+\mathrm{CH}_{4}$ & $1.75 \times 10^{-16}$ & 6 & 3043 \\
\hline 40 & $\mathrm{C}_{2} \mathrm{H}_{6}+\mathrm{C}_{2} \mathrm{H} \rightarrow \mathrm{C}_{2} \mathrm{H}_{2}+\mathrm{C}_{2} \mathrm{H}_{5}$ & $6.00 \times 10^{-12}$ & 0 & 0 \\
\hline 41 & $\mathrm{C}_{2} \mathrm{H}_{6}+\mathrm{H} \rightarrow \mathrm{C}_{2} \mathrm{H}_{5}+\mathrm{H}_{2}$ & $1.23 \times 10^{-11}$ & 1.5 & 3730 \\
\hline 42 & $\mathrm{C}_{2} \mathrm{H}_{2}+\mathrm{H} \rightarrow \mathrm{C}_{2} \mathrm{H}+\mathrm{H}_{2}$ & $1.00 \times 10^{-10}$ & 0 & 0 \\
\hline 43 & $\mathrm{C}_{2} \mathrm{H}_{4}+\mathrm{H} \rightarrow \mathrm{C}_{2} \mathrm{H}_{3}+\mathrm{H}_{2}$ & $9.00 \times 10^{-10}$ & 0 & 0 \\
\hline 44 & $\mathrm{CH}_{2}+\mathrm{C}_{2} \mathrm{H}_{6} \rightarrow \mathrm{C}_{3} \mathrm{H}_{8}$ & $4.00 \times 10^{-10}$ & 0 & 0 \\
\hline 45 & $\mathrm{CH}_{2}+\mathrm{C}_{3} \mathrm{H}_{8} \rightarrow \mathrm{C}_{4} \mathrm{H}_{10}$ & $1.89 \times 10^{-12}$ & 0 & 0 \\
\hline
\end{tabular}


Table 7. Different species considered in the $\mathrm{C}_{2} \mathrm{H}_{2} / \mathrm{H}_{2}$ model, besides electrons

\begin{tabular}{ccc}
\hline \hline Molecules & Ions & Radicals \\
\hline $\mathrm{H}_{2}$ & $\mathrm{H}^{+}, \mathrm{H}_{2}{ }^{+}$, & $\mathrm{H}$ \\
$\mathrm{C}_{2} \mathrm{H}_{2}$ & $\mathrm{C}_{2} \mathrm{H}_{2}{ }^{+}, \mathrm{C}_{2} \mathrm{H}^{+}, \mathrm{CH}^{+}, \mathrm{CH}_{2}^{+}$, & $\mathrm{C}, \mathrm{CH}, \mathrm{CH}_{2}, \mathrm{C}_{2}, \mathrm{C}_{2} \mathrm{H}$ \\
$\mathrm{C}_{2}^{+}, \mathrm{C}^{+}$ & \\
$\mathrm{C}_{4} \mathrm{H}_{2}, \mathrm{C}_{6} \mathrm{H}_{2}, \mathrm{C}_{8} \mathrm{H}_{2}$, & $\mathrm{C}_{4} \mathrm{H}^{+}, \mathrm{C}_{6} \mathrm{H}^{+}, \mathrm{C}_{8} \mathrm{H}^{+}$, & $\mathrm{C}_{4} \mathrm{H}, \mathrm{C}_{6} \mathrm{H}, \mathrm{C}_{8} \mathrm{H}$, \\
$\mathrm{C}_{10} \mathrm{H}_{2}, \mathrm{C}_{12} \mathrm{H}_{2}$ & $\mathrm{C}_{4} \mathrm{H}_{2}{ }^{+}, \mathrm{C}_{6} \mathrm{H}_{2}{ }^{+}, \mathrm{C}_{8} \mathrm{H}_{2}{ }^{+}$ & $\mathrm{C}_{10} \mathrm{H}, \mathrm{C}_{12} \mathrm{H}$ \\
& $\mathrm{C}_{2} \mathrm{H}_{3}{ }^{+}, \mathrm{C}_{4} \mathrm{H}_{3}{ }^{+}$ & \\
$\mathrm{C}_{6} \mathrm{H}_{4}, \mathrm{C}_{8} \mathrm{H}_{4}, \mathrm{C}_{8} \mathrm{H}_{6}, \mathrm{C}_{10} \mathrm{H}_{6}$, & $\mathrm{C}_{6} \mathrm{H}_{4}{ }^{+}, \mathrm{C}_{8} \mathrm{H}_{4}{ }^{+}, \mathrm{C}_{8} \mathrm{C}_{4} \mathrm{H}_{3}, \mathrm{C}_{6} \mathrm{H}_{3}$, & \\
$\mathrm{C}_{12} \mathrm{H}_{6}$ & $\mathrm{C}_{10} \mathrm{H}_{6}{ }^{+}, \mathrm{C}_{12} \mathrm{H}_{6}{ }^{+}$ & \\
\hline \hline
\end{tabular}


Table 8. Electron impact collisions included in the $\mathrm{C}_{2} \mathrm{H}_{2} / \mathrm{H}_{2}$ model and their corresponding threshold energies, and the references where the cross sections are adopted from.

\begin{tabular}{|c|c|c|c|c|}
\hline No. & Reaction & Threshold Energy $(\mathrm{eV})$ & Reaction Type & Reference \\
\hline 1 & $\mathrm{C}_{2} \mathrm{H}_{2}+\mathrm{e}^{-} \rightarrow \mathrm{C}_{2} \mathrm{H}_{2}^{+}+2 \mathrm{e}^{-}$ & 11.4 & Ionization & [65] \\
\hline 2 & $\mathrm{C}_{2} \mathrm{H}_{2}+\mathrm{e}^{-} \rightarrow \mathrm{C}_{2} \mathrm{H}^{+}+\mathrm{H}+2 \mathrm{e}^{-}$ & 16.5 & Dissociative ionization & [65] \\
\hline 3 & $\mathrm{C}_{2} \mathrm{H}_{2}+\mathrm{e}^{-} \rightarrow \mathrm{C}_{2}^{+}+\mathrm{H}_{2}+2 \mathrm{e}^{-}$ & 17.5 & Dissociative ionization & [65] \\
\hline 4 & $\mathrm{C}_{2} \mathrm{H}_{2}+\mathrm{e}^{-} \rightarrow \mathrm{CH}^{+}+\mathrm{CH}+2 \mathrm{e}^{-}$ & 20.6 & Dissociative ionization & [65] \\
\hline 5 & $\mathrm{C}_{2} \mathrm{H}_{2}+\mathrm{e}^{-} \rightarrow \mathrm{C}^{+}+\mathrm{CH}_{2}+2 \mathrm{e}^{-}$ & 20.3 & Dissociative ionization & [65] \\
\hline 6 & $\mathrm{C}_{2} \mathrm{H}_{2}+\mathrm{e}^{-} \rightarrow \mathrm{H}^{+}+\mathrm{C}_{2} \mathrm{H}+2 \mathrm{e}^{-}$ & 18.4 & Dissociative ionization & [65] \\
\hline 7 & $\mathrm{C}_{2} \mathrm{H}_{2}{ }^{(0)}+\mathrm{e}^{-} \rightarrow \mathrm{C}_{2} \mathrm{H}_{2}{ }^{(\mathrm{v} v 5)}+\mathrm{e}^{-}$ & 0.09 & Vibrational excitation & [64] \\
\hline 8 & $\mathrm{C}_{2} \mathrm{H}_{2}{ }^{(0)}+\mathrm{e}^{-} \rightarrow \mathrm{C}_{2} \mathrm{H}_{2}{ }^{(\mathrm{v}=2)}+\mathrm{e}^{-}$ & 0.29 & Vibrational excitation & [64] \\
\hline 9 & $\mathrm{C}_{2} \mathrm{H}_{2}{ }^{(0)}+\mathrm{e}^{-} \rightarrow \mathrm{C}_{2} \mathrm{H}_{2}{ }^{(\mathrm{v}=3)}+\mathrm{e}^{-}$ & 0.41 & Vibrational excitation & [64] \\
\hline 10 & $\mathrm{C}_{2} \mathrm{H}_{2}+\mathrm{e}^{-} \rightarrow \mathrm{C}_{2} \mathrm{H}+\mathrm{H}+\mathrm{e}^{-}$ & 7.5 & Dissociation & [65] \\
\hline 11 & $\mathrm{H}_{2}+\mathrm{e}^{-} \rightarrow \mathrm{H}_{2}+\mathrm{e}^{-}$ & 0.0 & Momentum transfer & [56] \\
\hline 12 & $\mathrm{H}_{2}{ }^{(\mathrm{j}=0)}+\mathrm{e}^{-} \rightarrow \mathrm{H}_{2}{ }^{(\mathrm{j}=2)}+\mathrm{e}^{-}$ & 0.044 & Rotational excitation & [56] \\
\hline 13 & $\mathrm{H}_{2}{ }^{(\mathrm{j}=1)}+\mathrm{e}^{-} \rightarrow \mathrm{H}_{2}{ }^{(\mathrm{j}=3)}+\mathrm{e}^{-}$ & 0.073 & Rotational excitation & [56] \\
\hline 14 & $\mathrm{H}_{2}{ }^{(\mathrm{v}=0)}+\mathrm{e}^{-} \rightarrow \mathrm{H}_{2}{ }^{(\mathrm{v}=1)}+\mathrm{e}^{-}$ & 0.516 & Vibrational excitation & [56] \\
\hline 15 & $\mathrm{H}_{2}{ }^{(\mathrm{v}=0)}+\mathrm{e}^{-} \rightarrow \mathrm{H}_{2}{ }^{(\mathrm{v}=2)}+\mathrm{e}^{-}$ & 1.000 & Vibrational excitation & [56] \\
\hline 16 & $\mathrm{H}_{2}{ }^{(\mathrm{v}=0)}+\mathrm{e}^{-} \rightarrow \mathrm{H}_{2}{ }^{(\mathrm{v}=3)}+\mathrm{e}^{-}$ & 1.500 & Vibrational excitation & [56] \\
\hline 17 & $\mathrm{H}_{2}+\mathrm{e}^{-} \rightarrow \mathrm{H}_{2}(\mathrm{~b} 3)+\mathrm{e}^{-}$ & 8.900 & Electronic excitation & [56] \\
\hline 18 & $\mathrm{H}_{2}+\mathrm{e}^{-} \rightarrow \mathrm{H}_{2}(\mathrm{~B} 1)+\mathrm{e}^{-}$ & 11.300 & Electronic excitation & [56] \\
\hline 19 & $\mathrm{H}_{2}+\mathrm{e}^{-} \rightarrow \mathrm{H}_{2}(\mathrm{c} 3)+\mathrm{e}^{-}$ & 11.75 & Electronic excitation & [56] \\
\hline 20 & $\mathrm{H}_{2}+\mathrm{e}^{-} \rightarrow \mathrm{H}_{2}(\mathrm{a} 3)+\mathrm{e}^{-}$ & 11.800 & Electronic excitation & [56] \\
\hline 21 & $\mathrm{H}_{2}+\mathrm{e}^{-} \rightarrow \mathrm{H}_{2}(\mathrm{C} 1)+\mathrm{e}^{-}$ & 12.400 & Electronic excitation & [56] \\
\hline 22 & $\mathrm{H}_{2}+\mathrm{e}^{-} \rightarrow \mathrm{H}_{2}(\mathrm{~d} 3)+\mathrm{e}^{-}$ & 14.000 & Electronic excitation & [56] \\
\hline 23 & $\mathrm{H}_{2}+\mathrm{e}^{-} \rightarrow \mathrm{H}+\mathrm{H}+\mathrm{e}^{-}$ & 8.870 & Dissociation & [56] \\
\hline 24 & $\mathrm{H}_{2}+\mathrm{e}^{-} \rightarrow \mathrm{H}_{2}^{+}+2 \mathrm{e}^{-}$ & 15.400 & Ionization & [56] \\
\hline 25 & $\mathrm{C}_{4} \mathrm{H}_{2}+\mathrm{e}^{-} \rightarrow \mathrm{C}_{4} \mathrm{H}+\mathrm{H}+\mathrm{e}^{-}$ & 7.5 & Dissociation & [65] \\
\hline 26 & $\mathrm{C}_{6} \mathrm{H}_{2}+\mathrm{e}^{-} \rightarrow \mathrm{C}_{6} \mathrm{H}+\mathrm{H}+\mathrm{e}^{-}$ & 7.5 & Dissociation & [65] \\
\hline 27 & $\mathrm{C}_{8} \mathrm{H}_{2}+\mathrm{e}^{-} \rightarrow \mathrm{C}_{8} \mathrm{H}+\mathrm{H}+\mathrm{e}^{-}$ & 7.5 & Dissociation & [65] \\
\hline 28 & $\mathrm{C}_{10} \mathrm{H}_{2}+\mathrm{e}^{-} \rightarrow \mathrm{C}_{10} \mathrm{H}+\mathrm{H}+\mathrm{e}^{-}$ & 7.5 & Dissociation & [65] \\
\hline 29 & $\mathrm{C}_{12} \mathrm{H}_{2}+\mathrm{e}^{-} \rightarrow \mathrm{C}_{12} \mathrm{H}+\mathrm{H}+\mathrm{e}^{-}$ & 7.5 & Dissociation & [65] \\
\hline 30 & $\mathrm{C}_{4} \mathrm{H}_{2}+\mathrm{e}^{-} \rightarrow \mathrm{C}_{4} \mathrm{H}_{2}^{+}+2 \mathrm{e}^{-}$ & 10.19 & Ionization & [69] \\
\hline 31 & $\mathrm{C}_{6} \mathrm{H}_{2}+\mathrm{e}^{-} \rightarrow \mathrm{C}_{6} \mathrm{H}_{2}^{+}+2 \mathrm{e}^{-}$ & 9.55 & Ionization & [69] \\
\hline
\end{tabular}


Table 9. Ion-molecule reactions taken into account in the $\mathrm{C}_{2} \mathrm{H}_{2} / \mathrm{H}_{2}$ model, as well as their reaction rate coefficients. The latter were all adopted from [66].

\begin{tabular}{|c|c|c|}
\hline No & $\begin{array}{r}\text { Reaction } \\
\end{array}$ & Coefficient $\left(\mathrm{cm}^{3} \mathrm{~s}^{-1}\right)$ \\
\hline 1 & $\mathrm{H}^{+}+\mathrm{C}_{2} \rightarrow \mathrm{C}_{2}^{+}+\mathrm{H}$ & $3.10 \times 10^{-9}$ \\
\hline 2 & $\mathrm{H}^{+}+\mathrm{C}_{4} \mathrm{H} \rightarrow \mathrm{C}_{4} \mathrm{H}^{+}+\mathrm{H}$ & $2.00 \times 10^{-9}$ \\
\hline 3 & $\mathrm{H}^{+}+\mathrm{C}_{6} \mathrm{H} \rightarrow \mathrm{C}_{6} \mathrm{H}^{+}+\mathrm{H}$ & $2.00 \times 10^{-9}$ \\
\hline 4 & $\mathrm{H}^{+}+\mathrm{C}_{8} \mathrm{H} \rightarrow \mathrm{C}_{8} \mathrm{H}^{+}+\mathrm{H}$ & $2.00 \times 10^{-9}$ \\
\hline 5 & $\mathrm{H}^{+}+\mathrm{C}_{2} \mathrm{H}_{2} \rightarrow \mathrm{C}_{2} \mathrm{H}^{+}+\mathrm{H}_{2}$ & $4.30 \times 10^{-9}$ \\
\hline 6 & $\mathrm{H}^{+}+\mathrm{C}_{4} \mathrm{H}_{2} \rightarrow \mathrm{C}_{4} \mathrm{H}^{+}+\mathrm{H}_{2}$ & $2.00 \times 10^{-9}$ \\
\hline 7 & $\mathrm{H}^{+}+\mathrm{C}_{8} \mathrm{H}_{2} \rightarrow \mathrm{C}_{8} \mathrm{H}^{+}+\mathrm{H}_{2}$ & $2.00 \times 10^{-9}$ \\
\hline 8 & $\mathrm{H}_{2}^{+}+\mathrm{H} \rightarrow \mathrm{H}^{+}+\mathrm{H}_{2}$ & $6.40 \times 10^{-10}$ \\
\hline 9 & $\mathrm{H}_{2}^{+}+\mathrm{C}_{2} \rightarrow \mathrm{C}_{2}^{+}+\mathrm{H}_{2}$ & $1.10 \times 10^{-9}$ \\
\hline 10 & $\mathrm{H}_{2}^{+}+\mathrm{C}_{2} \mathrm{H}_{2} \rightarrow \mathrm{C}_{2} \mathrm{H}_{2}^{+}+\mathrm{H}_{2}$ & $5.30 \times 10^{-9}$ \\
\hline 11 & $\mathrm{H}_{2}^{+}+\mathrm{C}_{4} \mathrm{H} \rightarrow \mathrm{C}_{4} \mathrm{H}_{2}^{+}+\mathrm{H}$ & $1.70 \times 10^{-10}$ \\
\hline 12 & $\mathrm{H}_{2}+\mathrm{C}_{2} \mathrm{H}^{+} \rightarrow \mathrm{C}_{2} \mathrm{H}_{2}^{+}+\mathrm{H}$ & $1.70 \times 10^{-9}$ \\
\hline 13 & $\mathrm{H}_{2}+\mathrm{C}_{8} \mathrm{H}^{+} \rightarrow \mathrm{C}_{8} \mathrm{H}_{2}^{+}+\mathrm{H}$ & $1.00 \times 10^{-9}$ \\
\hline 14 & $\mathrm{C}_{2} \mathrm{H}+\mathrm{C}_{4} \mathrm{H}^{+} \rightarrow \mathrm{C}_{6} \mathrm{H}^{+}+\mathrm{H}$ & $6.00 \times 10^{-10}$ \\
\hline 15 & $\mathrm{C}_{2} \mathrm{H}+\mathrm{C}_{4} \mathrm{H}_{2}^{+} \rightarrow \mathrm{C}_{6} \mathrm{H}_{2}^{+}+\mathrm{H}$ & $1.30 \times 10^{-9}$ \\
\hline 16 & $\mathrm{C}_{2} \mathrm{H}+\mathrm{C}_{6} \mathrm{H}_{2}^{+} \rightarrow \mathrm{C}_{8} \mathrm{H}_{2}^{+}+\mathrm{H}$ & $1.20 \times 10^{-9}$ \\
\hline 17 & $\mathrm{C}_{2} \mathrm{H}_{2}+\mathrm{C}_{2}^{+} \rightarrow \mathrm{C}_{4} \mathrm{H}^{+}+\mathrm{H}$ & $1.70 \times 10^{-9}$ \\
\hline 18 & $\mathrm{C}_{2} \mathrm{H}_{2}+\mathrm{C}_{2} \mathrm{H}^{+} \rightarrow \mathrm{C}_{4} \mathrm{H}_{2}^{+}+\mathrm{H}$ & $1.20 \times 10^{-9}$ \\
\hline 19 & $\mathrm{C}_{2} \mathrm{H}_{2}+\mathrm{C}_{2} \mathrm{H}_{3}^{+} \rightarrow \mathrm{C}_{4} \mathrm{H}_{3}^{+}+\mathrm{H}_{2}$ & $2.40 \times 10^{-10}$ \\
\hline 20 & $\mathrm{C}_{2} \mathrm{H}_{2}+\mathrm{C}_{4} \mathrm{H}^{+} \rightarrow \mathrm{C}_{6} \mathrm{H}_{2}^{+}+\mathrm{H}$ & $1.50 \times 10^{-9}$ \\
\hline 21 & $\mathrm{C}_{2} \mathrm{H}_{2}+\mathrm{C}_{4} \mathrm{H}_{2}^{+} \rightarrow \mathrm{C}_{6} \mathrm{H}_{4}^{+}$ & $1.40 \times 10^{-10}$ \\
\hline 22 & $\mathrm{C}_{2} \mathrm{H}_{2}+\mathrm{C}_{2} \mathrm{H}_{2}^{+} \rightarrow \mathrm{C}_{4} \mathrm{H}_{3}^{+}+\mathrm{H}$ & $9.50 \times 10^{-10}$ \\
\hline 23 & $\mathrm{C}_{2} \mathrm{H}_{2}+\mathrm{C}_{2} \mathrm{H}_{2}^{+} \rightarrow \mathrm{C}_{4} \mathrm{H}_{2}^{+}+\mathrm{H}_{2}$ & $1.20 \times 10^{-9}$ \\
\hline 24 & $\mathrm{C}_{2} \mathrm{H}_{2}+\mathrm{C}_{6} \mathrm{H}_{4}^{+} \rightarrow \mathrm{C}_{8} \mathrm{H}_{6}^{+}$ & $1.00 \times 10^{-10}$ \\
\hline 25 & $\mathrm{C}_{2} \mathrm{H}_{2}+\mathrm{C}_{8} \mathrm{H}_{4}^{+} \rightarrow \mathrm{C}_{10} \mathrm{H}_{6}^{+}$ & $5.00 \times 10^{-11}$ \\
\hline 26 & $\mathrm{C}_{2} \mathrm{H}_{2}+\mathrm{C}_{8} \mathrm{H}_{6}^{+} \rightarrow \mathrm{C}_{10} \mathrm{H}_{6}^{+}+\mathrm{H}_{2}$ & $5.00 \times 10^{-11}$ \\
\hline 27 & $\mathrm{C}_{2} \mathrm{H}_{2}+\mathrm{C}_{10} \mathrm{H}_{6}^{+} \rightarrow \mathrm{C}_{12} \mathrm{H}_{6}^{+}+\mathrm{H}_{2}$ & $1.00 \times 10^{-11}$ \\
\hline 28 & $\mathrm{C}_{2} \mathrm{H}_{2}+\mathrm{C}_{6} \mathrm{H}_{2}^{+} \rightarrow \mathrm{C}_{8} \mathrm{H}_{4}^{+}$ & $1.00 \times 10^{-11}$ \\
\hline 29 & $\mathrm{C}_{2} \mathrm{H}_{2}+\mathrm{C}_{6} \mathrm{H}_{2}^{+} \rightarrow \mathrm{C}_{8} \mathrm{H}_{2}^{+}+\mathrm{H}_{2}$ & $1.00 \times 10^{-11}$ \\
\hline 30 & $\mathrm{C}_{2} \mathrm{H}_{2}^{+}+\mathrm{H}_{2} \rightarrow \mathrm{C}_{2} \mathrm{H}_{3}^{+}+\mathrm{H}$ & $1.00 \times 10^{-11}$ \\
\hline 31 & $\mathrm{C}_{2} \mathrm{H}_{2}^{+}+\mathrm{C}_{6} \mathrm{H}_{2} \rightarrow \mathrm{C}_{8} \mathrm{H}_{2}^{+}+\mathrm{H}_{2}$ & $5.00 \times 10^{-10}$ \\
\hline 32 & $\mathrm{C}_{2} \mathrm{H}_{2}^{+}+\mathrm{C}_{6} \mathrm{H} \rightarrow \mathrm{C}_{8} \mathrm{H}_{2}^{+}+\mathrm{H}$ & $1.20 \times 10^{-9}$ \\
\hline 33 & $\mathrm{C}_{2} \mathrm{H}_{2}^{+}+\mathrm{C}_{6} \mathrm{H}_{2} \rightarrow \mathrm{C}_{6} \mathrm{H}_{2}^{+}+\mathrm{C}_{2} \mathrm{H}_{2}$ & $5.00 \times 10^{-10}$ \\
\hline 34 & $\mathrm{C}_{2} \mathrm{H}_{2}^{+}+\mathrm{C}_{6} \mathrm{H} \rightarrow \mathrm{C}_{8} \mathrm{H}^{+}+\mathrm{H}_{2}$ & $1.20 \times 10^{-09}$ \\
\hline
\end{tabular}




\begin{tabular}{lll}
35 & $\mathrm{C}_{2} \mathrm{H}_{3}+\mathrm{C}_{2} \mathrm{H}_{2}{ }^{+} \rightarrow \mathrm{C}_{4} \mathrm{H}_{3}^{+}+\mathrm{H}_{2}$ & $3.30 \times 10^{-10}$ \\
36 & $\mathrm{C}_{2} \mathrm{H}_{3}+\mathrm{C}_{4} \mathrm{H}_{2}^{+} \rightarrow \mathrm{C}_{6} \mathrm{H}_{4}^{+}+\mathrm{H}$ & $1.20 \times 10^{-9}$ \\
37 & $\mathrm{C}_{2} \mathrm{H}_{3}+\mathrm{C}_{4} \mathrm{H}_{3}^{+} \rightarrow \mathrm{C}_{6} \mathrm{H}_{4}^{+}+\mathrm{H}_{2}$ & $5.00 \times 10^{-10}$ \\
38 & $\mathrm{C}_{2} \mathrm{H}_{3}+\mathrm{C}_{6} \mathrm{H}_{2}{ }^{+} \rightarrow \mathrm{C}_{8} \mathrm{H}_{4}^{+}+\mathrm{H}$ & $4.00 \times 10^{-10}$ \\
39 & $\mathrm{C}_{2} \mathrm{H}_{3}^{+}+\mathrm{H} \rightarrow \mathrm{C}_{2} \mathrm{H}_{2}^{+}+\mathrm{H}_{2}$ & $6.80 \times 10^{-11}$ \\
40 & $\mathrm{C}_{2} \mathrm{H}_{3}^{+}+\mathrm{C}_{6} \mathrm{H} \rightarrow \mathrm{C}_{8} \mathrm{H}_{2}^{+}+\mathrm{H}_{2}$ & $5.00 \times 10^{-10}$ \\
41 & $\mathrm{C}_{2} \mathrm{H}_{3}^{+}+\mathrm{C}_{4} \mathrm{H} \rightarrow \mathrm{C}_{6} \mathrm{H}_{2}^{+}+\mathrm{H}_{2}$ & $4.00 \times 10^{-10}$ \\
42 & $\mathrm{C}_{2} \mathrm{H}_{3}^{+}+\mathrm{C}_{6} \mathrm{H} \rightarrow \mathrm{C}_{6} \mathrm{H}_{2}^{+}+\mathrm{C}_{2} \mathrm{H}_{2}$ & $5.00 \times 10^{-10}$ \\
43 & $\mathrm{C}_{2}^{+}+\mathrm{H}_{2} \rightarrow \mathrm{C}_{2} \mathrm{H}^{+}+\mathrm{H}^{+9}$ & $1.10 \times 10^{-9}$ \\
44 & $\mathrm{C}_{4} \mathrm{H}^{+}+\mathrm{C}_{4} \mathrm{H} \rightarrow \mathrm{C}_{8} \mathrm{H}^{+}+\mathrm{H}$ & $6.00 \times 10^{-10}$ \\
45 & $\mathrm{C}_{4} \mathrm{H}^{+}+\mathrm{C}_{4} \mathrm{H}_{2} \rightarrow \mathrm{C}_{8} \mathrm{H}_{2}^{+}+\mathrm{H}$ & $1.50 \times 10^{-9}$ \\
\hline \hline
\end{tabular}


Table 10. Neutral-neutral reactions taken into account in the $\mathrm{C}_{2} \mathrm{H}_{2} / \mathrm{H}_{2}$ model. The rate coefficients are calculated by $\mathrm{k}=\mathrm{k}_{0} \times\left(\mathrm{T}_{\mathrm{g}} / 298\right)^{\mathrm{n}} \times \exp \left(-\mathrm{E}_{\mathrm{a}} / \mathrm{RT}_{\mathrm{g}}\right)$, where $\mathrm{T}_{\mathrm{g}}$ is the gas temperature $(\mathrm{K})$. The parameters $\mathrm{k}_{0}, \mathrm{n}$, and $\mathrm{E}_{\mathrm{a}}$ are given in the table, as well as the references where these data are adopted from.

\begin{tabular}{|c|c|c|c|c|c|}
\hline \multirow{2}{*}{ No. } & \multirow{2}{*}{ Reactions } & \multicolumn{3}{|c|}{ Rate coefficient } & \multirow{2}{*}{ Ref. } \\
\hline & & $\mathrm{k}_{0}\left(\mathrm{~cm}^{3} \mathrm{~s}^{-1}\right)$ & $\mathrm{n}$ & $\mathrm{Ea} / \mathrm{R}(\mathrm{K})$ & \\
\hline 1 & $\mathrm{C}_{2} \mathrm{H}+\mathrm{C}_{2} \mathrm{H}_{2} \rightarrow \mathrm{C}_{4} \mathrm{H}_{2}+\mathrm{H}$ & $1.30 \times 10^{-10}$ & 0.0 & 0.0 & [70] \\
\hline 2 & $\mathrm{C}_{2} \mathrm{H}+\mathrm{C}_{4} \mathrm{H}_{2} \rightarrow \mathrm{C}_{6} \mathrm{H}_{2}+\mathrm{H}$ & $1.30 \times 10^{-10}$ & 0.0 & 0.0 & [70] \\
\hline 3 & $\mathrm{C}_{2} \mathrm{H}+\mathrm{C}_{6} \mathrm{H}_{2} \rightarrow \mathrm{C}_{8} \mathrm{H}_{2}+\mathrm{H}$ & $1.30 \times 10^{-10}$ & 0.0 & 0.0 & [70] \\
\hline 4 & $\mathrm{C}_{2} \mathrm{H}+\mathrm{C}_{8} \mathrm{H}_{2} \rightarrow \mathrm{C}_{10} \mathrm{H}_{2}+\mathrm{H}$ & $1.30 \times 10^{-10}$ & 0.0 & 0.0 & [70] \\
\hline 5 & $\mathrm{C}_{2} \mathrm{H}+\mathrm{C}_{10} \mathrm{H}_{2} \rightarrow \mathrm{C}_{12} \mathrm{H}_{2}+\mathrm{H}$ & $1.30 \times 10^{-10}$ & 0.0 & 0.0 & [70] \\
\hline 6 & $\mathrm{C}_{2} \mathrm{H}+\mathrm{C}_{2} \mathrm{H}_{2} \rightarrow \mathrm{C}_{4} \mathrm{H}_{3}$ & $4.70 \times 10^{-10}$ & -6.3 & 1404.0 & [71] \\
\hline 7 & $\mathrm{C}_{2} \mathrm{H}+\mathrm{C}_{4} \mathrm{H}_{2} \rightarrow \mathrm{C}_{6} \mathrm{H}_{3}$ & $4.70 \times 10^{-10}$ & -6.3 & 1404.0 & [71] \\
\hline 8 & $\mathrm{H}+\mathrm{C}_{2} \mathrm{H}_{3} \rightarrow \mathrm{C}_{2} \mathrm{H}_{2}+\mathrm{H}_{2}$ & $5.00 \times 10^{-11}$ & 0.0 & 0.0 & [70] \\
\hline 9 & $\mathrm{H}+\mathrm{C}_{4} \mathrm{H}_{3} \rightarrow \mathrm{C}_{4} \mathrm{H}_{2}+\mathrm{H}_{2}$ & $2.40 \times 10^{-11}$ & 0.0 & 0.0 & [71] \\
\hline 10 & $\mathrm{H}+\mathrm{C}_{6} \mathrm{H}_{3} \rightarrow \mathrm{C}_{6} \mathrm{H}_{2}+\mathrm{H}_{2}$ & $5.00 \times 10^{-11}$ & 0.0 & 0.0 & {$[72]$} \\
\hline 11 & $\mathrm{C}_{4} \mathrm{H}+\mathrm{C}_{2} \mathrm{H}_{2} \rightarrow \mathrm{C}_{6} \mathrm{H}_{2}+\mathrm{H}$ & $6.60 \times 10^{-11}$ & 0.0 & 0.0 & [73] \\
\hline 12 & $\mathrm{C}_{6} \mathrm{H}+\mathrm{C}_{2} \mathrm{H}_{2} \rightarrow \mathrm{C}_{8} \mathrm{H}_{2}+\mathrm{H}$ & $6.60 \times 10^{-11}$ & 0.0 & 0.0 & [73] \\
\hline 13 & $\mathrm{C}_{8} \mathrm{H}+\mathrm{C}_{2} \mathrm{H}_{2} \rightarrow \mathrm{C}_{10} \mathrm{H}_{2}+\mathrm{H}$ & $6.60 \times 10^{-11}$ & 0.0 & 0.0 & [73] \\
\hline 14 & $\mathrm{C}_{10} \mathrm{H}+\mathrm{C}_{2} \mathrm{H}_{2} \rightarrow \mathrm{C}_{12} \mathrm{H}_{2}+\mathrm{H}$ & $6.60 \times 10^{-11}$ & 0.0 & 0.0 & [73] \\
\hline 15 & $\mathrm{H}+\mathrm{C}_{4} \mathrm{H}_{3} \rightarrow \mathrm{C}_{2} \mathrm{H}_{2}+\mathrm{C}_{2} \mathrm{H}_{2}$ & $2.91 \times 10^{-9}$ & -1.6 & 1117.0 & {$[71]$} \\
\hline 16 & $\mathrm{H}+\mathrm{C}_{6} \mathrm{H}_{3} \rightarrow \mathrm{C}_{4} \mathrm{H}_{2}+\mathrm{C}_{2} \mathrm{H}_{2}$ & $4.38 \times 10^{-9}$ & -1.6 & 1117.0 & [71] \\
\hline 17 & $\mathrm{C}_{2} \mathrm{H}+\mathrm{C}_{2} \mathrm{H}_{3} \rightarrow \mathrm{C}_{2} \mathrm{H}_{2}+\mathrm{C}_{2} \mathrm{H}_{2}$ & $5.00 \times 10^{-11}$ & 0.0 & 0.0 & [71] \\
\hline 18 & $\mathrm{C}_{2} \mathrm{H}_{2}+\mathrm{H} \rightarrow \mathrm{C}_{2} \mathrm{H}_{3}$ & $1.40 \times 10^{-11}$ & 0.0 & 1300.0 & [71] \\
\hline 19 & $\mathrm{C}_{4} \mathrm{H}_{2}+\mathrm{H} \rightarrow \mathrm{C}_{4} \mathrm{H}_{3}$ & $5.31 \times 10^{-11}$ & 1.16 & 882.0 & [74] \\
\hline 20 & $\mathrm{C}_{2} \mathrm{H}+\mathrm{H}_{2} \rightarrow \mathrm{C}_{2} \mathrm{H}_{2}+\mathrm{H}$ & $8.95 \times 10^{-13}$ & 2.57 & 130.0 & [70] \\
\hline 21 & $\mathrm{C}_{4} \mathrm{H}+\mathrm{H}_{2} \rightarrow \mathrm{C}_{4} \mathrm{H}_{2}+\mathrm{H}$ & $8.95 \times 10^{-13}$ & 2.57 & 130.0 & [70] \\
\hline 22 & $\mathrm{C}_{6} \mathrm{H}+\mathrm{H}_{2} \rightarrow \mathrm{C}_{6} \mathrm{H}_{2}+\mathrm{H}$ & $8.95 \times 10^{-13}$ & 2.57 & 130.0 & [70] \\
\hline 23 & $\mathrm{C}_{8} \mathrm{H}+\mathrm{H}_{2} \rightarrow \mathrm{C}_{8} \mathrm{H}_{2}+\mathrm{H}$ & $8.95 \times 10^{-13}$ & 2.57 & 130.0 & [70] \\
\hline 24 & $\mathrm{C}_{10} \mathrm{H}+\mathrm{H}_{2} \rightarrow \mathrm{C}_{10} \mathrm{H}_{2}+\mathrm{H}$ & $8.95 \times 10^{-13}$ & 2.57 & 130.0 & [70] \\
\hline 25 & $\mathrm{C}_{12} \mathrm{H}+\mathrm{H}_{2} \rightarrow \mathrm{C}_{12} \mathrm{H}_{2}+\mathrm{H}$ & $8.95 \times 10^{-13}$ & 2.57 & 130.0 & [70] \\
\hline 26 & $\mathrm{CH}+\mathrm{H}_{2} \rightarrow \mathrm{CH}_{2}+\mathrm{H}$ & $3.75 \times 10^{-10}$ & 0.0 & 1660.0 & {$[71]$} \\
\hline 27 & $\mathrm{CH}_{2}+\mathrm{H} \rightarrow \mathrm{CH}+\mathrm{H}_{2}$ & $5.30 \times 10^{-11}$ & 0.0 & 0.0 & [71] \\
\hline 28 & $\mathrm{CH}_{2}+\mathrm{CH} \rightarrow \mathrm{C}_{2} \mathrm{H}_{2}+\mathrm{H}$ & $8.30 \times 10^{-11}$ & 0.0 & 0.0 & [71] \\
\hline 29 & $\mathrm{C}_{2} \mathrm{H}_{3}+\mathrm{CH} \rightarrow \mathrm{C}_{2} \mathrm{H}_{2}+\mathrm{CH}_{2}$ & $8.30 \times 10^{-11}$ & 0.0 & 0.0 & [71] \\
\hline
\end{tabular}


Table 11. Extra species considered when ammonia is included in the gas mixture

\begin{tabular}{ccc}
\hline \hline Molecules & Ions & Radicals \\
\hline $\mathrm{NH}_{3}$ & $\mathrm{NH}^{+}, \mathrm{NH}_{2}{ }^{+}, \mathrm{NH}_{3}{ }^{+}, \mathrm{NH}_{4}{ }^{+}$ & $\mathrm{NH}_{2}, \mathrm{NH}$ \\
$\mathrm{N}_{2} \mathrm{H}_{2}, \mathrm{~N}_{2} \mathrm{H}_{4}$ & & $\mathrm{~N}_{2} \mathrm{H}, \mathrm{N}_{2} \mathrm{H}_{3}$ \\
$\mathrm{~N}_{2}$ & $\mathrm{~N}^{+}, \mathrm{N}_{2}^{+}$ & $\mathrm{N}, \mathrm{N}^{*}, \mathrm{~N}_{2}{ }^{*}$ \\
$\mathrm{HCN}$ & $\mathrm{HCN}^{+}$ & $\mathrm{H}_{2} \mathrm{CN}, \mathrm{CN}$ \\
\hline \hline
\end{tabular}


Table 12. Extra electron impact collisions and their corresponding threshold energies, included when ammonia is used as dilution gas instead of $\mathrm{H}_{2}$. All these cross sections are adopted from [75].

\begin{tabular}{|c|c|c|c|}
\hline No. & Reaction & Threshold Energy (eV) & Reaction Type \\
\hline 1 & $\mathrm{NH}_{3}+\mathrm{e}^{-} \rightarrow \mathrm{NH}_{3}+\mathrm{e}^{-}$ & 0.0 & Momentum \\
\hline 2 & $\mathrm{NH}_{3}+\mathrm{e}^{-} \rightarrow \mathrm{NH}_{3}+\mathrm{e}^{-}$ & 0.1162 & Vibrational excitation \\
\hline 3 & $\mathrm{NH}_{3}+\mathrm{e}^{-} \rightarrow \mathrm{NH}_{3}+\mathrm{e}^{-}$ & 0.196 & Vibrational excitation \\
\hline 4 & $\mathrm{NH}_{3}+\mathrm{e}^{-} \rightarrow \mathrm{NH}_{3}+\mathrm{e}^{-}$ & 0.405 & Vibrational excitation \\
\hline 5 & $\mathrm{NH}_{3}+\mathrm{e}^{-} \rightarrow \mathrm{NH}_{2}+\mathrm{H}+\mathrm{e}^{-}$ & 5.6 & Dissociation \\
\hline 6 & $\mathrm{NH}_{3}+\mathrm{e}^{-} \rightarrow \mathrm{NH}+\mathrm{H}+\mathrm{H}+2 \mathrm{e}^{-}$ & 8.9 & Dissociation \\
\hline 7 & $\mathrm{NH}_{3}+\mathrm{e}^{-} \rightarrow \mathrm{NH}_{3}^{+}+2 \mathrm{e}^{-}$ & 10.2 & Ionization \\
\hline 8 & $\mathrm{NH}_{3}+\mathrm{e}^{-} \rightarrow \mathrm{NH}_{2}^{+}+\mathrm{H}+2 \mathrm{e}^{-}$ & 16.0 & Dissociative Ionization \\
\hline 9 & $\mathrm{NH}_{2}+\mathrm{e}^{-} \rightarrow \mathrm{NH}_{2}+\mathrm{e}^{-}$ & 0.0 & Momentum \\
\hline 10 & $\mathrm{NH}_{2}+\mathrm{e}^{-} \rightarrow \mathrm{NH}_{2}+\mathrm{e}^{-}$ & 0.1162 & Vibrational excitation \\
\hline 11 & $\mathrm{NH}_{2}+\mathrm{e}^{-} \rightarrow \mathrm{NH}_{2}+\mathrm{e}^{-}$ & 0.196 & Vibrational excitation \\
\hline 12 & $\mathrm{NH}_{2}+\mathrm{e}^{-} \rightarrow \mathrm{NH}_{2}+\mathrm{e}^{-}$ & 0.405 & Vibrational excitation \\
\hline 13 & $\mathrm{NH}_{2}+\mathrm{e}^{-} \rightarrow \mathrm{NH}+\mathrm{H}+\mathrm{e}^{-}$ & 5.6 & Dissociation \\
\hline 14 & $\mathrm{NH}_{2}+\mathrm{e}^{-} \rightarrow \mathrm{N}+\mathrm{H}+\mathrm{H}+2 \mathrm{e}^{-}$ & 8.9 & Dissociation \\
\hline 15 & $\mathrm{NH}_{2}+\mathrm{e}^{-} \rightarrow \mathrm{NH}_{2}^{+}+2 \mathrm{e}^{-}$ & 11.14 & Ionization \\
\hline 16 & $\mathrm{NH}_{2}+\mathrm{e}^{-} \rightarrow \mathrm{NH}^{+}+\mathrm{H}+2 \mathrm{e}^{-}$ & 17.60 & Dissociative Ionization \\
\hline 17 & $\mathrm{NH}+\mathrm{e}^{-} \rightarrow \mathrm{NH}+\mathrm{e}^{-}$ & 0.0 & Momentum \\
\hline 18 & $\mathrm{NH}+\mathrm{e}^{-} \rightarrow \mathrm{NH}+\mathrm{e}^{-}$ & 0.1162 & Vibrational excitation \\
\hline 19 & $\mathrm{NH}+\mathrm{e}^{-} \rightarrow \mathrm{NH}+\mathrm{e}^{-}$ & 0.196 & Vibrational excitation \\
\hline 20 & $\mathrm{NH}+\mathrm{e}^{-} \rightarrow \mathrm{NH}+\mathrm{e}^{-}$ & 0.405 & Vibrational excitation \\
\hline 21 & $\mathrm{NH}+\mathrm{e}^{-} \rightarrow \mathrm{N}+\mathrm{H}+\mathrm{e}^{-}$ & 5.6 & Dissociation \\
\hline 22 & $\mathrm{NH}+\mathrm{e}^{-} \rightarrow \mathrm{NH}^{+}+2 \mathrm{e}^{-}$ & 13.49 & Ionization \\
\hline 23 & $\mathrm{~N}_{2}+\mathrm{e}^{-} \rightarrow \mathrm{N}_{2}+\mathrm{e}^{-}$ & 0 & Momentum \\
\hline 24 & $\mathrm{~N}_{2}+\mathrm{e}^{-} \rightarrow \mathrm{N}_{2}+\mathrm{e}^{-}$ & 0.02 & Rotational excitation \\
\hline 25 & $\mathrm{~N}_{2}+\mathrm{e}^{-} \rightarrow \mathrm{N}_{2}+\mathrm{e}^{-}$ & 1.3 & Vibrational excitation \\
\hline 26 & $\mathrm{~N}_{2}+\mathrm{e}^{-} \rightarrow \mathrm{N}_{2}+\mathrm{e}^{-}$ & 1.73 & Vibrational excitation \\
\hline 27 & $\mathrm{~N}_{2}+\mathrm{e}^{-} \rightarrow \mathrm{N}_{2}+\mathrm{e}^{-}$ & 1.901 & Vibrational excitation \\
\hline 28 & $\mathrm{~N}_{2}+\mathrm{e}^{-} \rightarrow \mathrm{N}_{2}+\mathrm{e}^{-}$ & 2.079 & Vibrational excitation \\
\hline 29 & $\mathrm{~N}_{2}+\mathrm{e}^{-} \rightarrow \mathrm{N}_{2}+\mathrm{e}^{-}$ & 2.119 & Vibrational excitation \\
\hline 30 & $\mathrm{~N}_{2}+\mathrm{e}^{-} \rightarrow \mathrm{N}_{2}+\mathrm{e}^{-}$ & 2.297 & Vibrational excitation \\
\hline 31 & $\mathrm{~N}_{2}+\mathrm{e}^{-} \rightarrow \mathrm{N}_{2}+\mathrm{e}^{-}$ & 2.39 & Vibrational excitation \\
\hline 32 & $\mathrm{~N}_{2}+\mathrm{e}^{-} \rightarrow \mathrm{N}_{2}+\mathrm{e}^{-}$ & 2.60 & Vibrational excitation \\
\hline 33 & $\mathrm{~N}_{2}+\mathrm{e}^{-} \rightarrow \mathrm{N}_{2}{ }^{*}+\mathrm{e}^{-}$ & 6.17 & Electronic excitation \\
\hline 34 & $\mathrm{~N}_{2}+\mathrm{e}^{-} \rightarrow \mathrm{N}_{2}{ }^{*}+\mathrm{e}^{-}$ & 7.35 & Electronic excitation \\
\hline 35 & $\mathrm{~N}_{2}+\mathrm{e}^{-} \rightarrow \mathrm{N}_{2}{ }^{*}+\mathrm{e}^{-}$ & 8.165 & Electronic excitation \\
\hline 36 & $\mathrm{~N}_{2}+\mathrm{e}^{-} \rightarrow \mathrm{N}_{2}{ }^{*}+\mathrm{e}^{-}$ & 8.399 & Electronic excitation \\
\hline 37 & $\mathrm{~N}_{2}+\mathrm{e}^{-} \rightarrow \mathrm{N}_{2}^{*}+\mathrm{e}^{-}$ & 11.032 & Electronic excitation \\
\hline 38 & $\mathrm{~N}_{2}+\mathrm{e}^{-} \rightarrow \mathrm{N}+\mathrm{N}+\mathrm{e}^{-}$ & 12.253 & Dissociation \\
\hline 39 & $\mathrm{~N}_{2}+\mathrm{e}^{-} \rightarrow \mathrm{N}_{2}^{+}+2 \mathrm{e}^{-}$ & 15.5 & Ionization \\
\hline
\end{tabular}




\begin{tabular}{llcc}
$\mathbf{4 0}$ & $\mathrm{N}+\mathrm{e}^{-} \rightarrow \mathrm{N}+\mathrm{e}^{-}$ & 0 & Momentum \\
$\mathbf{4 1}$ & $\mathrm{N}+\mathrm{e}^{-} \rightarrow \mathrm{N}^{*}+\mathrm{e}^{-}$ & 2.38 & Electronic excitation \\
$\mathbf{4 2}$ & $\mathrm{N}+\mathrm{e}^{-} \rightarrow \mathrm{N}^{*}+\mathrm{e}^{-}$ & 3.57 & Electronic excitation \\
$\mathbf{4 3}$ & $\mathrm{N}+\mathrm{e}^{-} \rightarrow \mathrm{N}^{+}+2 \mathrm{e}^{-}$ & 14.549 & Ionization \\
\hline \hline
\end{tabular}

Table 13. Extra ion-molecule reactions taken into account when ammonia is used as dilution gas, as well as their rate coefficients and references where these data are adopted from. $\mathrm{T}_{\mathrm{g}}$ is the gas temperature $(\mathrm{K})$.

\begin{tabular}{|c|c|c|c|}
\hline No & Reaction & Coefficient $\left(\mathrm{cm}^{3} \mathrm{~s}^{-1}\right)$ & Reference \\
\hline 1 & $\mathrm{~N}_{2}^{+}+\mathrm{N} \rightarrow \mathrm{N}^{+}+\mathrm{N}_{2}$ & $5.00 \times 10^{-12}$ & {$[76]$} \\
\hline 2 & $\mathrm{~N}_{2}^{+}+\mathrm{N}^{*} \rightarrow \mathrm{N}^{+}+\mathrm{N}_{2}$ & $1.00 \times 10^{-10}$ & [76] \\
\hline 3 & $\mathrm{~N}_{2}^{+}+\mathrm{N}_{2} \rightarrow \mathrm{N}_{2}^{+}+\mathrm{N}_{2}$ & $1.00 \times 10^{-9}$ & [76] \\
\hline 4 & $\mathrm{~N}_{2}^{+}+\mathrm{N}_{2}^{*} \rightarrow \mathrm{N}_{2}^{+}+\mathrm{N}_{2}$ & $1.00 \times 10^{-9}$ & [76] \\
\hline 5 & $\mathrm{~N}^{+}+\mathrm{N} \rightarrow \mathrm{N}^{+}+\mathrm{N}$ & $1.00 \times 10^{-9}$ & [76] \\
\hline 6 & $\mathrm{~N}^{+}+\mathrm{N}^{*} \rightarrow \mathrm{N}^{+}+\mathrm{N}$ & $1.00 \times 10^{-9}$ & [76] \\
\hline 7 & $\mathrm{~N}^{+}+\mathrm{N}_{2} \rightarrow \mathrm{N}^{+}+\mathrm{N}_{2}$ & $1.00 \times 10^{-9}$ & [76] \\
\hline 8 & $\mathrm{~N}^{+}+\mathrm{N}_{2}^{*} \rightarrow \mathrm{N}^{+}+\mathrm{N}_{2}$ & $1.00 \times 10^{-9}$ & [76] \\
\hline 9 & $\mathrm{H}_{3}^{+}+\mathrm{NH}_{3} \rightarrow \mathrm{NH}_{4}^{+}+\mathrm{H}_{2}$ & $4.40 \times 10^{-9}$ & [76] \\
\hline 10 & $\mathrm{H}_{2}^{+}+\mathrm{NH} \rightarrow \mathrm{NH}^{+}+\mathrm{H}_{2}$ & $5.00 \times 10^{-10}$ & [76] \\
\hline 11 & $\mathrm{H}_{2}^{+}+\mathrm{NH} \rightarrow \mathrm{NH}_{2}^{+}+\mathrm{H}$ & $5.00 \times 10^{-11}$ & [76] \\
\hline 12 & $\mathrm{H}_{2}^{+}+\mathrm{NH}_{2} \rightarrow \mathrm{NH}_{2}^{+}+\mathrm{H}_{2}$ & $5.00 \times 10^{-10}$ & [76] \\
\hline 13 & $\mathrm{H}_{2}^{+}+\mathrm{NH}_{2} \rightarrow \mathrm{NH}_{3}^{+}+\mathrm{H}$ & $5.00 \times 10^{-11}$ & [76] \\
\hline 14 & $\mathrm{H}_{2}^{+}+\mathrm{NH}_{3} \rightarrow \mathrm{NH}_{3}^{+}+\mathrm{H}_{2}$ & $5.70 \times 10^{-9}$ & [76] \\
\hline 15 & $\mathrm{H}_{2}^{+}+\mathrm{NH}_{3} \rightarrow \mathrm{NH}_{4}^{+}+\mathrm{H}$ & $5.00 \times 10^{-11}$ & [76] \\
\hline 16 & $\mathrm{H}^{+}+\mathrm{NH}_{3} \rightarrow \mathrm{NH}_{3}^{+}+\mathrm{H}$ & $5.00 \times 10^{-11}$ & [76] \\
\hline 17 & $\mathrm{H}^{+}+\mathrm{NH}_{2} \rightarrow \mathrm{NH}_{2}^{+}+\mathrm{H}$ & $5.00 \times 10^{-11}$ & [76] \\
\hline 18 & $\mathrm{H}^{+}+\mathrm{NH} \rightarrow \mathrm{NH}^{+}+\mathrm{H}$ & $5.00 \times 10^{-11}$ & [76] \\
\hline 19 & $\mathrm{NH}^{+}+\mathrm{NH}_{3} \rightarrow \mathrm{NH}^{+}+\mathrm{NH}$ & $2.40 \times 10^{-9}$ & [76] \\
\hline 20 & $\mathrm{NH}^{+}+\mathrm{NH}_{3} \rightarrow \mathrm{NH}_{4}^{+}+\mathrm{N}$ & $1.80 \times 10^{-9}$ & [76] \\
\hline 21 & $\mathrm{NH}^{+}+\mathrm{H}_{2} \rightarrow \mathrm{NH}_{2}^{+}+\mathrm{H}$ & $1.00 \times 10^{-9}$ & [76] \\
\hline 22 & $\mathrm{NH}_{2}^{+}+\mathrm{NH}_{3} \rightarrow \mathrm{NH}_{3}^{+}+\mathrm{NH}_{2}$ & $2.20 \times 10^{-9}$ & [76] \\
\hline 23 & $\mathrm{NH}_{2}^{+}+\mathrm{NH}_{3} \rightarrow \mathrm{NH}_{4}^{+}+\mathrm{NH}$ & $2.20 \times 10^{-9}$ & [76] \\
\hline 24 & $\mathrm{NH}_{2}^{+}+\mathrm{H}_{2} \rightarrow \mathrm{NH}_{3}^{+}+\mathrm{H}$ & $1.00 \times 10^{-9}$ & [76] \\
\hline 25 & $\mathrm{NH}_{3}^{+}+\mathrm{NH}_{3} \rightarrow \mathrm{NH}_{4}^{+}+\mathrm{NH}_{2}$ & $2.20 \times 10^{-9}$ & [76] \\
\hline 26 & $\mathrm{NH}_{3}^{+}+\mathrm{H}_{2} \rightarrow \mathrm{NH}_{4}^{+}+\mathrm{H}$ & $4.00 \times 10^{-13}$ & [76] \\
\hline 27 & $\mathrm{NH}_{3}^{+}+\mathrm{H}_{2} \rightarrow \mathrm{H}_{2}^{+}+\mathrm{NH}_{3}$ & $9.63 \times 10^{-13}\left(\mathrm{~T}_{\mathrm{g}} / 298\right)^{-0.25} \operatorname{EXP}\left(-14.6 / \mathrm{T}_{\mathrm{g}}\right)$ & [27] \\
\hline 28 & $\mathrm{NH}_{3}^{+}+\mathrm{NH}_{3} \rightarrow \mathrm{H}^{+}+\mathrm{NH}_{2}+\mathrm{NH}_{3}$ & $6.87 \times 10^{-10}\left(\mathrm{~T}_{\mathrm{g}} / 298\right)^{-0.17} \mathrm{EXP}\left(-4.6 / \mathrm{T}_{\mathrm{g}}\right)$ & [27] \\
\hline 29 & $\mathrm{NH}_{3}^{+}+\mathrm{H}_{2} \rightarrow \mathrm{H}_{2}^{+}+\mathrm{NH}_{2}+\mathrm{H}$ & $2.18 \times 10^{-09}\left(\mathrm{~T}_{\mathrm{g}} / 298\right)^{-0.20} \operatorname{EXP}\left(-9.9 / \mathrm{T}_{\mathrm{g}}\right)$ & [27] \\
\hline 30 & $\mathrm{NH}_{3}^{+}+\mathrm{NH}_{3} \rightarrow \mathrm{NH}_{2}^{+}+\mathrm{H}_{2}+\mathrm{NH}_{2}$ & $6.12 \times 10^{-07}\left(\mathrm{~T}_{\mathrm{g}} / 298\right)^{-0.44} \operatorname{EXP}\left(-3.8 / \mathrm{T}_{\mathrm{g}}\right)$ & [27] \\
\hline 31 & $\mathrm{NH}_{3}^{+}+\mathrm{H}_{2} \rightarrow \mathrm{H}^{+}+\mathrm{NH}_{3}+\mathrm{H}$ & $8.46 \times 10^{-10}\left(\mathrm{~T}_{\mathrm{g}} / 298\right)^{-0.39} \operatorname{EXP}\left(-14.8 / \mathrm{T}_{\mathrm{g}}\right)$ & [27] \\
\hline 32 & $\mathrm{NH}_{2}^{+}+\mathrm{CH}_{4} \rightarrow \mathrm{NH}_{3}^{+}+\mathrm{CH}_{3}$ & $1.60 \times 10^{-9}$ & [66] \\
\hline 33 & $\mathrm{NH}_{3}^{+}+\mathrm{C}_{2} \mathrm{H}_{2} \rightarrow \mathrm{NH}_{4}^{+}+\mathrm{C}_{2} \mathrm{H}_{3}$ & $5.40 \times 10^{-10}$ & {$[66]$} \\
\hline 34 & $\mathrm{NH}_{2}^{+}+\mathrm{CH}_{4} \rightarrow \mathrm{NH}_{3}^{+}+\mathrm{CH}_{3}$ & $9.20 \times 10^{-10}$ & [66] \\
\hline 35 & $\mathrm{NH}_{3}^{+}+\mathrm{C}_{2} \mathrm{H}_{2} \rightarrow \mathrm{NH}_{4}^{+}+\mathrm{C}_{2} \mathrm{H}_{3}$ & $1.40 \times 10^{-9}$ & [66] \\
\hline 36 & $\mathrm{CH}_{4}^{+}+\mathrm{NH}_{3} \rightarrow \mathrm{NH}_{3}^{+}+\mathrm{CH}_{4}$ & $1.60 \times 10^{-9}$ & [66] \\
\hline 37 & $\mathrm{CH}_{4}^{+}+\mathrm{NH}_{3} \rightarrow \mathrm{NH}_{4}^{+}+\mathrm{CH}_{3}$ & $1.46 \times 10^{-9}$ & [66] \\
\hline 38 & $\mathrm{CH}_{5}^{+}+\mathrm{NH}_{3} \rightarrow \mathrm{NH}_{4}^{+}+\mathrm{CH}_{4}$ & $2.30 \times 10^{-9}$ & [66] \\
\hline 39 & $\mathrm{C}_{2} \mathrm{H}_{4}^{+}+\mathrm{NH}_{3} \rightarrow \mathrm{NH}_{3}^{+}+\mathrm{C}_{2} \mathrm{H}_{4}$ & $2.00 \times 10^{-10}$ & [66] \\
\hline 40 & $\mathrm{C}_{2} \mathrm{H}_{5}^{+}+\mathrm{NH}_{3} \rightarrow \mathrm{NH}_{4}^{+}+\mathrm{C}_{2} \mathrm{H}_{4}$ & $2.18 \times 10^{-9}$ & {$[66]$} \\
\hline
\end{tabular}




\begin{tabular}{llll}
41 & $\mathrm{C}_{2} \mathrm{H}_{6}{ }^{+}+\mathrm{NH}_{3} \rightarrow \mathrm{NH}_{3}{ }^{+}+\mathrm{C}_{2} \mathrm{H}_{6}$ & $6.60 \times 10^{-10}$ & {$[66]$} \\
42 & $\mathrm{C}_{2} \mathrm{H}_{6}{ }^{+}+\mathrm{NH}_{3} \rightarrow \mathrm{NH}_{4}{ }^{+}+\mathrm{C}_{2} \mathrm{H}_{5}$ & $1.30 \times 10^{-9}$ & {$[66]$} \\
43 & $\mathrm{H}_{2}{ }^{+}+\mathrm{CN} \rightarrow \mathrm{HCN}^{+}+\mathrm{H}$ & $1.20 \times 10^{-9}$ & {$[66]$} \\
44 & $\mathrm{H}_{2}{ }^{+}+\mathrm{HCN} \rightarrow \mathrm{HCN}^{+}+\mathrm{H}_{2}$ & $2.70 \times 10^{-9}$ & {$[66]$} \\
45 & $\mathrm{H}_{3}{ }^{+}+\mathrm{CN} \rightarrow \mathrm{HCN}^{+}+\mathrm{H}_{2}$ & $2.00 \times 10^{-9}$ & {$[66]$} \\
46 & $\mathrm{~N}^{+}+\mathrm{CH}_{4} \rightarrow \mathrm{HCN}^{+}+\mathrm{H}_{2}+\mathrm{H}$ & $5.60 \times 10^{-11}$ & {$[66]$} \\
47 & $\mathrm{~N}_{2}{ }^{+}+\mathrm{CH}_{4} \rightarrow \mathrm{CH}_{3}{ }^{+}+\mathrm{N}_{2}+\mathrm{H}$ & $9.30 \times 10^{-10}$ & {$[66]$} \\
48 & $\mathrm{~N}_{2}^{+}+\mathrm{HCN} \rightarrow \mathrm{HCN}^{+}+\mathrm{N}_{2}$ & $3.90 \times 10^{-10}$ & {$[66]$} \\
\hline
\end{tabular}

Table 14. Extra neutral-neutral reactions taken into account when ammonia is included as dilution gas. The rate coefficients are calculated by $\mathrm{k}=\mathrm{k}_{0} \times\left(\mathrm{T}_{\mathrm{g}} / 298\right)^{\mathrm{n}} \times \exp \left(-\mathrm{E}_{\mathrm{a}} / \mathrm{RT}_{\mathrm{g}}\right)$, where $\mathrm{T}_{\mathrm{g}}$ is the gas temperature $(\mathrm{K})$. The parameters $\mathrm{k}_{0}, \mathrm{n}$, and $\mathrm{E}_{\mathrm{a}}$ are given in the table, as well as the reference where these data are adopted from.

\begin{tabular}{|c|c|c|c|c|c|}
\hline \multirow{2}{*}{ No. } & \multirow{2}{*}{ Reactions } & \multicolumn{3}{|c|}{ Rate coefficient } & \multirow{2}{*}{ Ref. } \\
\hline & & $\mathrm{k}_{0}\left(\mathrm{~cm}^{3} \mathrm{~s}^{-1}\right)$ & $\mathrm{n}$ & $\mathrm{E}_{\mathrm{a}} / \mathrm{R}(\mathrm{K})$ & \\
\hline 1 & $\mathrm{~N}_{2}+\mathrm{N}_{2} \rightarrow \mathrm{N}+\mathrm{N}+\mathrm{N}_{2}$ & $4.29 \times 10^{-10}$ & 0 & 86460 & [77] \\
\hline 2 & $\mathrm{NH}_{3}+\mathrm{H} \rightarrow \mathrm{H}_{2}+\mathrm{NH}_{2}$ & $1.34 \times 10^{-10}$ & 0 & 7325 & [78] \\
\hline 3 & $\mathrm{NH}_{3}+\mathrm{NH}+\mathrm{M} \rightarrow \mathrm{N}_{2} \mathrm{H}_{4}+\mathrm{M}$ & $5.00 \times 10^{-35}$ & 0 & 0 & [79] \\
\hline 4 & $\mathrm{NH}_{2}+\mathrm{H} \rightarrow \mathrm{H}_{2}+\mathrm{NH}$ & $4.81 \times 10^{-12}$ & 0 & 0 & [80] \\
\hline 5 & $\mathrm{NH}_{2}+\mathrm{H}_{2} \rightarrow \mathrm{H}+\mathrm{NH}_{3}$ & $2.09 \times 10^{-12}$ & 0 & 4277 & [81] \\
\hline 6 & $\mathrm{NH}_{2}+\mathrm{NH}_{2} \rightarrow \mathrm{H}_{2}+\mathrm{N}_{2} \mathrm{H}_{2}$ & $8.31 \times 10^{-11}$ & 0 & 0 & [82] \\
\hline 7 & $\mathrm{NH}_{2}+\mathrm{NH}_{2} \rightarrow \mathrm{NH}_{3}+\mathrm{NH}$ & $8.31 \times 10^{-11}$ & 0 & 5100 & [83] \\
\hline 8 & $\mathrm{NH}_{2}+\mathrm{N} \rightarrow \mathrm{N}_{2}+\mathrm{H}+\mathrm{H}$ & $1.20 \times 10^{-10}$ & 0 & 0 & [81] \\
\hline 9 & $\mathrm{NH}_{2}+\mathrm{NH} \rightarrow \mathrm{H}+\mathrm{N}_{2} \mathrm{H}_{2}$ & $2.49 \times 10^{-9}$ & -0.50 & 0 & [81] \\
\hline 10 & $\mathrm{NH}_{2}+\mathrm{NH} \rightarrow \mathrm{N}_{2} \mathrm{H}_{3}$ & $1.16 \times 10^{-10}$ & 0 & 0 & [84] \\
\hline 11 & $\mathrm{NH}+\mathrm{N} \rightarrow \mathrm{N}_{2}+\mathrm{H}$ & $2.50 \times 10^{-11}$ & 0 & 0 & [76] \\
\hline 12 & $\mathrm{NH}_{2}+\mathrm{NH}+\mathrm{M} \rightarrow \mathrm{NH}_{3}+\mathrm{M}$ & $6.06 \times 10^{-30}$ & 0 & 0 & [79] \\
\hline 13 & $\mathrm{NH}+\mathrm{H} \rightarrow \mathrm{H}_{2}+\mathrm{N}$ & $5.98 \times 10^{-11}$ & 0 & 166 & [81] \\
\hline 14 & $\mathrm{NH}+\mathrm{H}_{2} \rightarrow \mathrm{H}+\mathrm{NH}_{2}$ & $5.96 \times 10^{-11}$ & 0 & 7782 & [79] \\
\hline 15 & $\mathrm{NH}+\mathrm{NH} \rightarrow \mathrm{N}_{2}+\mathrm{H}+\mathrm{H}$ & $1.16 \times 10^{-9}$ & 0 & 0 & [85] \\
\hline 16 & $\mathrm{NH}+\mathrm{NH} \rightarrow \mathrm{N}_{2} \mathrm{H}_{2}$ & $3.49 \times 10^{-12}$ & 0 & 0 & [86] \\
\hline 17 & $\mathrm{NH}+\mathrm{NH} \rightarrow \mathrm{NH}_{2}+\mathrm{N}$ & $1.40 \times 10^{-14}$ & 2.89 & -1015 & [87] \\
\hline 18 & $\mathrm{~N}+\mathrm{H}_{2} \rightarrow \mathrm{NH}+\mathrm{H}$ & $2.66 \times 10^{-10}$ & 0 & 12609 & [88] \\
\hline 19 & $\mathrm{H}+\mathrm{H}+\mathrm{NH}_{3} \rightarrow \mathrm{H}_{2}+\mathrm{NH}_{3}$ & $1.40 \times 10^{-31}$ & 0 & 0 & [89] \\
\hline 20 & $\mathrm{H}+\mathrm{H}+\mathrm{NH}_{2} \rightarrow \mathrm{H}_{2}+\mathrm{NH}_{2}$ & $1.40 \times 10^{-31}$ & 0 & 0 & [89] \\
\hline 21 & $\mathrm{~N}+\mathrm{H}+\mathrm{NH}_{3} \rightarrow \mathrm{NH}+\mathrm{NH}_{3}$ & $5.00 \times 10^{-32}$ & 0 & 0 & [81] \\
\hline 22 & $\mathrm{H}+\mathrm{N}+\mathrm{H} \rightarrow \mathrm{H}+\mathrm{NH}$ & $5.00 \times 10^{-32}$ & 0 & 0 & [81] \\
\hline 23 & $\mathrm{H}+\mathrm{NH}_{2}+\mathrm{NH}_{3} \rightarrow \mathrm{NH}_{3}+\mathrm{NH}_{3}$ & $6.00 \times 10^{-30}$ & 0 & 0 & [81] \\
\hline 24 & $\mathrm{~N}+\mathrm{H}+\mathrm{H} \rightarrow \mathrm{NH}+\mathrm{H}$ & $5.00 \times 10^{-32}$ & 0 & 0 & [81] \\
\hline 25 & $\mathrm{H}+\mathrm{NH}_{2}+\mathrm{H} \rightarrow \mathrm{NH}_{3}+\mathrm{H}$ & $6.00 \times 10^{-30}$ & 0 & 0 & [81] \\
\hline 26 & $\mathrm{H}+\mathrm{NH}_{2}+\mathrm{NH}_{2} \rightarrow \mathrm{NH}_{3}+\mathrm{NH}_{2}$ & $6.00 \times 10^{-30}$ & 0 & 0 & [81] \\
\hline 27 & $\mathrm{~N}_{2} \mathrm{H}_{2}+\mathrm{H} \rightarrow \mathrm{N}_{2}+\mathrm{H}+\mathrm{H}_{2}$ & $4.53 \times 10^{-13}$ & 2.63 & -115 & [89] \\
\hline 28 & $\mathrm{~N}_{2} \mathrm{H}_{2}+\mathrm{NH}_{2} \rightarrow \mathrm{N}_{2}+\mathrm{H}+\mathrm{NH}_{3}$ & $1.53 \times 10^{-15}$ & 4.05 & -810.7 & [90] \\
\hline 29 & $\mathrm{~N}_{2} \mathrm{H}_{3}+\mathrm{H} \rightarrow \mathrm{NH}_{2}+\mathrm{NH}_{2}$ & $2.66 \times 10^{-12}$ & 0 & 0 & [91] \\
\hline 30 & $\mathrm{~N}_{2} \mathrm{H}_{3}+\mathrm{N}_{2} \mathrm{H}_{3} \rightarrow \mathrm{NH}_{3}+\mathrm{NH}_{3}+\mathrm{N}_{2}$ & $5.00 \times 10^{-12}$ & 0 & 0 & [92] \\
\hline 31 & $\mathrm{~N}_{2} \mathrm{H}_{3}+\mathrm{N}_{2} \mathrm{H}_{3} \rightarrow \mathrm{N}_{2} \mathrm{H}_{4}+\mathrm{N}_{2} \mathrm{H}_{2}$ & $2.00 \times 10^{-11}$ & 0 & 0 & [93] \\
\hline 32 & $\mathrm{~N}_{2} \mathrm{H}_{4}+\mathrm{N} \rightarrow \mathrm{NH}_{2}+\mathrm{N}_{2} \mathrm{H}_{2}$ & $1.25 \times 10^{-13}$ & 0 & 0 & [91] \\
\hline 33 & $\mathrm{~N}_{2} \mathrm{H}_{4}+\mathrm{H} \rightarrow \mathrm{N}_{2} \mathrm{H}_{3}+\mathrm{H}_{2}$ & $1.17 \times 10^{-13}$ & 0 & 1260.5 & [94] \\
\hline 34 & $\mathrm{~N}_{2} \mathrm{H}_{4}+\mathrm{NH}_{2} \rightarrow \mathrm{NH}_{3}+\mathrm{N}_{2} \mathrm{H}_{3}$ & $5.15 \times 10^{-13}$ & 0 & 0 & [91] \\
\hline 35 & $\mathrm{~N}_{2} \mathrm{H}_{2}+\mathrm{H} \rightarrow \mathrm{N}_{2} \mathrm{H}+\mathrm{H}_{2}$ & $8.31 \times 10^{-11}$ & 0 & 510 & [79] \\
\hline 36 & $\mathrm{~N}_{2} \mathrm{H}_{2}+\mathrm{NH} \rightarrow \mathrm{N}_{2} \mathrm{H}+\mathrm{NH}_{2}$ & $1.66 \times 10^{-11}$ & 0 & 510 & [79] \\
\hline 37 & $\mathrm{~N}_{2} \mathrm{H}_{2}+\mathrm{NH}_{2} \rightarrow \mathrm{N}_{2} \mathrm{H}+\mathrm{NH}_{3}$ & $1.66 \times 10^{-11}$ & 0 & 510 & [79] \\
\hline 38 & $\mathrm{~N}_{2} \mathrm{H}+\mathrm{H} \rightarrow \mathrm{N}_{2}+\mathrm{H}_{2}$ & $6.64 \times 10^{-11}$ & 0 & 1531 & [79] \\
\hline 39 & $\mathrm{~N}_{2} \mathrm{H}+\mathrm{NH} \rightarrow \mathrm{N}_{2}+\mathrm{NH}_{2}$ & $8.31 \times 10^{-11}$ & 0 & 0 & [79] \\
\hline
\end{tabular}




\begin{tabular}{|c|c|c|c|c|c|}
\hline 40 & $\mathrm{~N}_{2} \mathrm{H}+\mathrm{NH}_{2} \rightarrow \mathrm{N}_{2}+\mathrm{NH}_{3}$ & $8.31 \times 10^{-11}$ & 0 & 0 & [79] \\
\hline 41 & $\mathrm{~N}_{2}^{*}+\mathrm{N}_{2} \rightarrow \mathrm{N}_{2}+\mathrm{N}_{2}$ & $1.90 \times 10^{-13}$ & 0 & 0 & [95] \\
\hline 42 & $\mathrm{~N}_{2}^{*}+\mathrm{N} \rightarrow \mathrm{N}+\mathrm{N}_{2}$ & $1.00 \times 10^{-13}$ & 0 & 0 & [95] \\
\hline 43 & $\mathrm{~N}_{2}^{*}+\mathrm{N}^{*} \rightarrow \mathrm{N}+\mathrm{N}_{2}$ & $1.00 \times 10^{-13}$ & 0 & 0 & [95] \\
\hline 44 & $\mathrm{~N}^{*}+\mathrm{N}_{2} \rightarrow \mathrm{N}+\mathrm{N}_{2}$ & $2.00 \times 10^{-14}$ & 0 & 0 & [95] \\
\hline 45 & $\mathrm{~N}^{*}+\mathrm{N}+\mathrm{M} \rightarrow \mathrm{N}_{2}{ }^{*}+\mathrm{M}$ & $2.00 \times 10^{-32}$ & 0 & 0 & [95] \\
\hline 46 & $\mathrm{~N}+\mathrm{N}+\mathrm{M} \rightarrow \mathrm{N}_{2}^{*}+\mathrm{M}$ & $1.00 \times 10^{-32}$ & 0 & 0 & [95] \\
\hline 47 & $\mathrm{~N}+\mathrm{N}+\mathrm{M} \rightarrow \mathrm{N}_{2}+\mathrm{M}$ & $1.00 \times 10^{-32}$ & 0 & 0 & [95] \\
\hline 48 & $\mathrm{~N}_{2}^{*}+\mathrm{N}_{2} \rightarrow \mathrm{N}_{2}+\mathrm{N}_{2}^{*}$ & $1.36 \times 10^{-09}$ & 0 & 0 & [95] \\
\hline 48 & $\mathrm{H}+\mathrm{H}+\mathrm{N}_{2} \rightarrow \mathrm{H}_{2}+\mathrm{N}_{2}$ & $9.11 \times 10^{-33}$ & -1.32 & 0 & {$[95]$} \\
\hline 49 & $\mathrm{CH}_{4}+\mathrm{N}_{2}^{*} \rightarrow \mathrm{CH}_{3}+\mathrm{H}+\mathrm{N}_{2}$ & $1.50 \times 10^{-12}$ & 0 & 0 & {$[96,97]$} \\
\hline 50 & $\mathrm{CH}_{3}+\mathrm{N}_{2}^{*} \rightarrow \mathrm{CH}_{2}+\mathrm{H}+\mathrm{N}_{2}$ & $4.50 \times 10^{-11}$ & 0 & 0 & {$[96,97]$} \\
\hline 51 & $\mathrm{CH}_{2}+\mathrm{N}_{2}^{*} \rightarrow \mathrm{CH}+\mathrm{H}+\mathrm{N}_{2}$ & $3.80 \times 10^{-13}$ & 0 & 0 & {$[96,97]$} \\
\hline 52 & $\mathrm{CH}+\mathrm{N}_{2}^{*} \rightarrow \mathrm{C}+\mathrm{H}+\mathrm{N}_{2}$ & $1.50 \times 10^{-12}$ & 0 & 0 & {$[96,97]$} \\
\hline 53 & $\mathrm{C}_{2} \mathrm{H}_{6}+\mathrm{N}_{2}^{*} \rightarrow \mathrm{C}_{2} \mathrm{H}_{5}+\mathrm{H}+\mathrm{N}_{2}$ & $3.60 \times 10^{-12}$ & 0 & 0 & {$[96,97]$} \\
\hline 54 & $\mathrm{CH}_{4}+\mathrm{N}^{*} \rightarrow \mathrm{CH}_{3}+\mathrm{NH}$ & $1.50 \times 10^{-12}$ & 0 & 0 & {$[96,97]$} \\
\hline 55 & $\mathrm{CH}_{3}+\mathrm{N} \rightarrow \mathrm{HCN}+\mathrm{H}_{2}$ & $1.40 \times 10^{-11}$ & 0 & 0 & {$[96,97]$} \\
\hline 56 & $\mathrm{CH}_{3}+\mathrm{N} \rightarrow \mathrm{H}_{2} \mathrm{CN}+\mathrm{H}$ & $1.30 \times 10^{-10}$ & 0 & 0 & {$[96,97]$} \\
\hline 57 & $\mathrm{CH}_{2}+\mathrm{N} \rightarrow \mathrm{HCN}+\mathrm{H}$ & $8.30 \times 10^{-11}$ & 0 & 0 & {$[96,97]$} \\
\hline 58 & $\mathrm{CH}_{2}+\mathrm{N} \rightarrow \mathrm{CN}+\mathrm{H}_{2}$ & $1.60 \times 10^{-11}$ & 0 & 0 & {$[96,97]$} \\
\hline 59 & $\mathrm{CH}+\mathrm{N} \rightarrow \mathrm{CN}+\mathrm{H}$ & $2.10 \times 10^{-11}$ & 0 & 0 & {$[96,97]$} \\
\hline 60 & $\mathrm{CH}_{4}+\mathrm{CN} \rightarrow \mathrm{HCN}+\mathrm{CH}_{3}$ & $7.00 \times 10^{-13}$ & 2.30 & 16.0 & {$[96,97]$} \\
\hline 61 & $\mathrm{H}_{2} \mathrm{CN}+\mathrm{N} \rightarrow \mathrm{HCN}+\mathrm{NH}$ & $6.70 \times 10^{-10}$ & 0 & 0 & {$[96,97]$} \\
\hline 62 & $\mathrm{CN}+\mathrm{H}_{2} \rightarrow \mathrm{HCN}+\mathrm{H}$ & $4.80 \times 10^{-13}$ & 2.60 & -960.0 & {$[96,97]$} \\
\hline 63 & $\mathrm{~N}+\mathrm{C}_{2} \mathrm{H}_{4} \rightarrow \mathrm{HCN}+\mathrm{CH}_{3}$ & $1.66 \times 10^{-14}$ & 0 & 0 & {$[96,97]$} \\
\hline 64 & $\mathrm{C}_{2} \mathrm{H}_{6}+\mathrm{CN} \rightarrow \mathrm{HCN}+\mathrm{C}_{2} \mathrm{H}_{5}$ & $1.79 \times 10^{-12}$ & 2.70 & -810 & {$[96,97]$} \\
\hline 65 & $\mathrm{C}_{2} \mathrm{H}_{4}+\mathrm{CN} \rightarrow \mathrm{HCN}+\mathrm{C}_{2} \mathrm{H}_{3}$ & $2.09 \times 10^{-10}$ & 0 & 0 & {$[96,97]$} \\
\hline 66 & $\mathrm{CH}_{3}+\mathrm{H}+\mathrm{N}_{2} \rightarrow \mathrm{CH}_{4}+\mathrm{N}_{2}$ & $6.00 \times 10^{-29}$ & -1.80 & 0 & {$[96,97]$} \\
\hline 67 & $\mathrm{C}_{2} \mathrm{H}_{2}+\mathrm{H}+\mathrm{N}_{2} \rightarrow \mathrm{C}_{2} \mathrm{H}_{3}+\mathrm{N}_{2}$ & $1.08 \times 10^{-25}$ & -7.27 & 3623 & {$[96,97]$} \\
\hline
\end{tabular}


Table 15. Sticking coefficients used in the model for all the radicals

\begin{tabular}{|c|c|c|c|c|c|}
\hline Species & Sticking coefficient & Reference & Species & Sticking coefficient & Reference \\
\hline $\mathrm{H}$ & 0.01 & {$[98]$} & $\mathrm{C}_{6} \mathrm{H}$ & 0.80 & {$[99]$} \\
\hline $\mathrm{C}$ & 1.00 & {$[99]$} & $\mathrm{C}_{6} \mathrm{H}_{3}$ & 0.30 & {$[99]$} \\
\hline $\mathrm{CH}$ & 1.00 & {$[99]$} & $\mathrm{C}_{8} \mathrm{H}$ & 0.80 & {$[99]$} \\
\hline $\mathrm{CH}_{2}$ & 0.26 & {$[99]$} & $\mathrm{C}_{10} \mathrm{H}$ & 0.80 & {$[99]$} \\
\hline $\mathrm{CH}_{3}$ & 0.001 & {$[99]$} & $\mathrm{C}_{12} \mathrm{H}$ & 0.80 & {$[99]$} \\
\hline $\mathrm{C}_{2}$ & 1.00 & {$[99]$} & $\mathrm{CN}$ & 0.85 & {$[100]$} \\
\hline $\mathrm{C}_{2} \mathrm{H}$ & 0.80 & {$[99]$} & $\mathrm{N}$ & 0.005 & {$[81]$} \\
\hline $\mathrm{C}_{2} \mathrm{H}_{3}$ & 0.30 & {$[99]$} & $\mathrm{NH}$ & 0.11 & {$[100]$} \\
\hline $\mathrm{C}_{2} \mathrm{H}_{5}$ & 0.01 & {$[99]$} & $\mathrm{NH}_{2}$ & 0.6 & {$[100]$} \\
\hline $\mathrm{C}_{4} \mathrm{H}$ & 0.80 & {$[99]$} & $\mathrm{N}_{2} \mathrm{H}$ & 0.14 & {$[81]$} \\
\hline $\mathrm{C}_{4} \mathrm{H}_{3}$ & 0.30 & {$[99]$} & $\mathrm{N}_{2} \mathrm{H}_{3}$ & 0.05 & {$[81]$} \\
\hline
\end{tabular}

Table 16. Decomposition rate (DR) of the background gas molecules, calculated for the four different gas mixtures and two pressure values under study. The negative values mean that more background gas species are formed instead of decomposed.

\begin{tabular}{|c|c|c|c|}
\hline & DR & 50mTorr & 1Torr \\
\hline \multirow{2}{*}{$\mathbf{C H}_{4} / \mathbf{H}_{2}$} & $\mathrm{CH}_{4}$ & $49.62 \%$ & $2.92 \%$ \\
\cline { 2 - 4 } & $\mathrm{H}_{2}$ & $8.74 \%$ & $0.20 \%$ \\
\hline \multirow{2}{*}{$\mathbf{C H}_{4} / \mathbf{N H}_{3}$} & $\mathrm{CH}_{4}$ & $75.14 \%$ & $71.87 \%$ \\
\cline { 2 - 4 } & $\mathrm{NH}_{3}$ & $89.92 \%$ & $89.50 \%$ \\
\hline \multirow{2}{*}{$\mathbf{C}_{2} \mathbf{H}_{2} / \mathbf{H}_{2}$} & $\mathrm{C}_{2} \mathrm{H}_{2}$ & $85.40 \%$ & $69.59 \%$ \\
\cline { 2 - 4 } & $\mathrm{H}_{2}$ & $-7.93 \%$ & $-16.27 \%$ \\
\hline \multirow{2}{*}{$\mathbf{C}_{2} \mathbf{H}_{2} / \mathbf{N H}_{3}$} & $\mathrm{C}_{2} \mathrm{H}_{2}$ & $84.76 \%$ & $96.09 \%$ \\
\cline { 2 - 4 } & $\mathrm{NH}_{3}$ & $83.59 \%$ & $97.02 \%$ \\
\hline
\end{tabular}

